\title{
Measuring Fiscal Disparities Across the U.S. States: A Representative Revenue System/ Representative Expenditure System Approach, Fiscal Year 2002
}

\author{
NEPPC Working Paper 06-2 \\ A joint report with the Urban-Brookings Tax Policy Center \\ by Yesim Yilmaz, Sonya Hoo, Matthew Nagowski, \\ Kim Rueben, and Robert Tannenwald
}

\begin{abstract}
States and their local governments vary both in their needs to provide basic public services and in their abilities to raise revenues to pay for those services. A joint study by the Tax Policy Center and the New England Policy Center at the Federal Reserve Bank of Boston uses the Representative Revenue System (RRS) and the Representative Expenditure System (RES) frameworks to quantify these disparities across states by comparing each state's revenue capacity, revenue effort, and necessary expenditures to the average capacity, effort, and need in states across the country for fiscal year 2002.

The fiscal capacity of a state is the state's revenue capacity relative to its expenditure need. A state with low fiscal capacity has a relatively small revenue base, a relatively high need for expenditures, or-as is often the case- a combination of both.

The New England and Mid-Atlantic states tend to have high revenue capacity and low expenditure needs compared to the national average. Thus, states in these two regions tend to have high fiscal capacity, or a relatively high capability to cover their expenditure needs using own resources. South Central states, on the other hand, have low fiscal capacity — that is, a low level of revenue-raising capacity given what it would cost to provide a standard set of public services to their citizens.

Little relation exists between the amount of federal aid received by states and their fiscal capacity; federal money is not primarily distributed to offset differences in the ability to raise revenues or provide services. Given the current level of federal funds allocated to state and local governments, 91 percent of the gap between revenue capacity and expenditure need across the states could be covered if federal funds were reallocated.
\end{abstract}

JEL Classification: H71, H72, H73

Keywords: state and local government taxation, state and local government expenditures, interjurisdictional differences 
Copyright (9) October 2006. The Urban Institute. Permission is granted for reproduction of this document, with attribution to the Urban Institute and the New England Public Policy Center at the Federal Reserve Bank of Boston.

This report is part of the Urban Institute's Assessing the Nerw Federalism project, a multiyear effort to monitor and assess the devolution of social programs from the federal to the state and local levels. Olivia Golden is the project director. The project analyzes changes in income support, social services, and health programs.

This project received funding from the Assessing the New Federalism and from the UrbanBrookings Tax Policy Center. The Assessing the New Federalism project is currently supported by The Annie E. Casey Foundation, The Robert Wood Johnson Foundation, The John D. and Catherine T. MacArthur Foundation, The California Endowment, and the Charles Stewart Mott Foundation. The Tax Policy Center is currently supported by The Annie E. Casey Foundation, the Charles Stewart Mott Foundation, the John D. and Catherine T. MacArthur Foundation, the Sandler Family Supporting Foundation, and private and anonymous donors.

The authors thank Leonard Burman, Carol Cohen, Nicholas Johnson, Olivia Golden, Rudy Penner, Robert Rafuse, and Gene Steuerle for their comments and recommendations and Susan Kellam and Fiona Blackshaw for editing the report. Robert Ebel deserves special thanks for beginning this project at the Urban Institute, providing early guidance and comments throughout the process. Gregory Wiles and Carol Rosenberg both provided ample research assistance on this project.

The nonpartisan Urban Institute publishes studies, reports, and books on timely topics worthy of public consideration. The views expressed are those of the authors and should not be attributed to the Urban Institute, its trustees, or its funders, nor to the Federal Reserve Bank of Boston or the Federal Reserve System. 


\section{Contents}

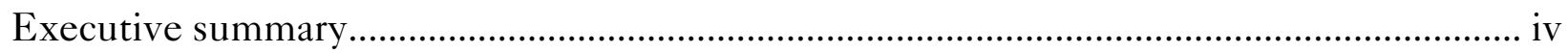

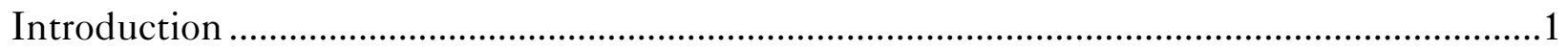

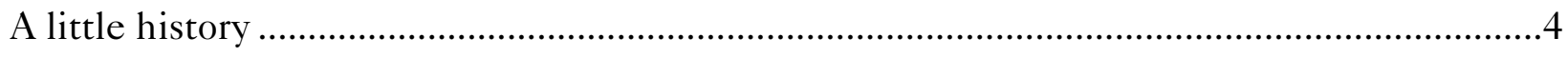

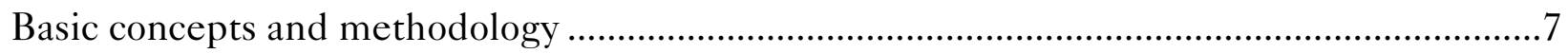

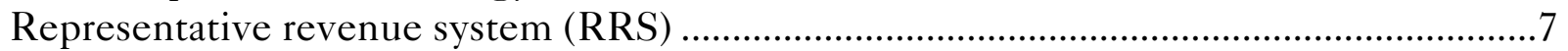

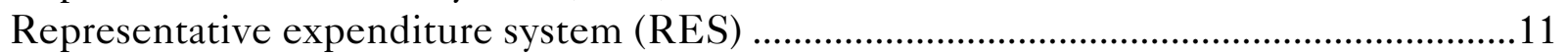

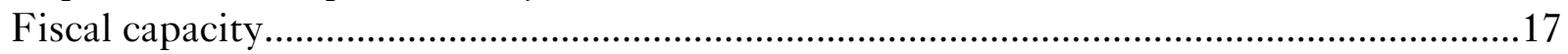

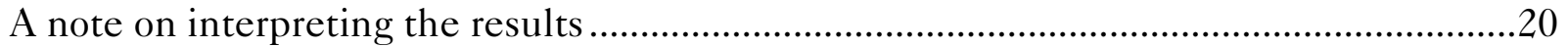

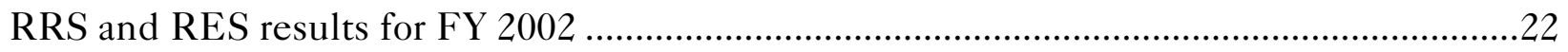

Representative revenue system ..................................................................................22

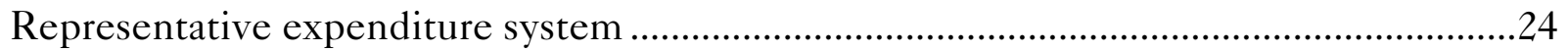

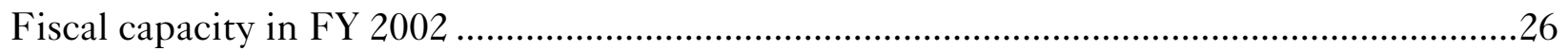

Closing the fiscal gap: Federal intergovernmental transfers .................................................28

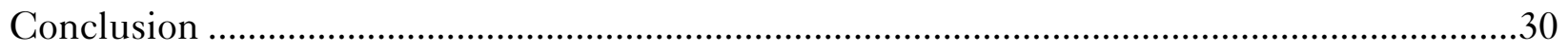

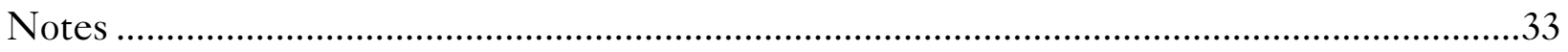

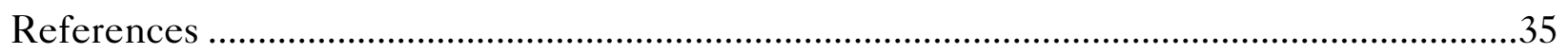

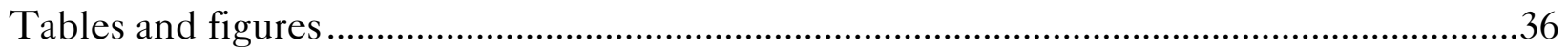

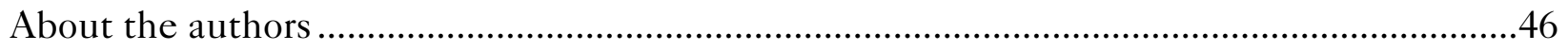

Appendices:

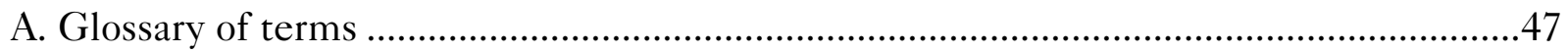

B. Data sources and methodology for representative revenue system (RRS), 2002 ..........49

C. Data sources and methodology for representative expenditure system (RES), 2002 ...65

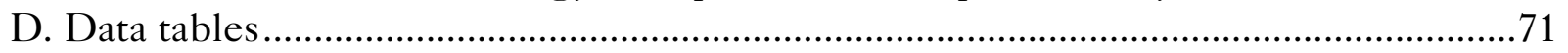




\title{
Measuring Fiscal Disparities Across the U.S. States: \\ A Representative Revenue System/ Representative Expenditure System Approach, Fiscal Year 2002
}

\author{
NEPPC Working Paper 06-2 \\ A joint report with the Urban-Brookings Tax Policy Center \\ by Yesim Yilmaz, Sonya Hoo, Matthew Nagowski, \\ Kim Rueben, and Robert Tannenwald
}

\section{Executive summary}

This report measures the fiscal disparities across the 50 states in fiscal year 2002 by looking at each state's revenue capacity, expenditure need, and overall level of fiscal capacity.' Because tax authority and expenditure responsibilities are assigned to different levels of governments across different states, we combine information about revenues raised and expenditure needs for each state and its local governments. ${ }^{2}$ We use a methodology based on the underlying economic and demographic conditions found in the states rather than actual revenue and expenditure levels. A state's revenue capacity measures the resources its state and local governments can tap to finance public services. A state's expenditure need gauges the extent to which its state and local governments face conditions that raise or lower the cost of and need for public services. Fiscal capacity assesses each state's ability to raise revenues relative to its expenditure needs. This is the first such study undertaken by the Tax Policy Center in collaboration with the New England Public Policy Center at the Federal Reserve Bank of Boston.

\section{Methodology and definitions}

In assessing fiscal capacity and need, we use the representative revenue system (RRS) and the representative expenditure system (RES) frameworks. The RRS and RES methodologies were developed in 1962 and 1986, respectively, by the U.S. Advisory Commission on Intergovernmental Relations (ACIR). After the ACIR was disbanded in 1995, Robert Tannenwald continued the reports through fiscal year 1999 (FY 1999). We extend this earlier work using fiscal year 2002 (FY 2002) data.

Measuring fiscal disparities requires a state-by-state construction of estimated revenues and expenditures based on typical tax and expenditure policies across the nation. Our calculations take into account the underlying demographic, socioeconomic, and geographical structure of each state to calculate the state's revenue base and expenditure need. These revenue and expenditure estimates are independent of states' actual tax and expenditure policies, or the division of power between each state and its local governments. 
In this report, we have updated the methodology used to estimate expenditure need after a re-examination of the demographic measures that track most closely with the programs that make up the bulk of state expenditures. In particular, we have updated the measures used to calculate expenditure need for education to reflect recent research on the added cost of educating children in poverty, as well as changes in adopted policies (such as No Child Left Behind) that add to that cost. We have also updated the measures used to calculate expenditure need for the welfare category, which largely is made up of state Medicaid expenditures. Our update adds a measure of the state's elderly population in poverty, an important driver of Medicaid costs.

On the revenue side,

- The tax capacity of a given state is the taxes the state would have collected if it were to tax every potentially taxable item at the representative tax rate-the national average of state tax rates weighted by the size of each state's tax base.

- The revenue capacity of each state includes tax capacity as well as potential nontax revenue from such sources as user charges, lotteries, income from sale of property, or interest income; again, we assume that a state levies charges and collects other revenues at representative levels. A state is said to have a high revenue (tax) effort if its actual revenues (tax collections) exceed its revenue (tax) capacity.

On the expenditure side,

- A state's expenditure need is the amount that a state would have to spend on its residents to provide services on par with the national average. Expenditure need is calculated across seven broad spending categories, and state amounts can differ based on differences in population or other factors. For example, all other things being equal, a state with a large percentage of its population between the ages of 5 and 18 has a higher need for spending on education than one with fewer school-age children. A state with a high expenditure effort spends more than its expenditure need.

The fiscal capacity of a state is the state's revenue capacity relative to its expenditure need. A state with low fiscal capacity has a relatively small revenue base, a relatively high need for expenditures, or-as is often the case-a combination of both. Low fiscal capacity does not necessarily imply a weak fiscal position. States with low fiscal capacity could maintain fiscal health (that is, setting revenues equal to expenditures) using a high revenue effort, low actual expenditures, or through transfers from the federal government. Low fiscal capacity states may have less ability to weather economic shocks, a condition illustrated in the aftermath of Hurricane Katrina. Louisiana, Mississippi and Alabama-the three states hit hardest by Katrina—are among the states with the lowest revenue capacity, highest expenditure need, and lowest fiscal capacity.

Differences across states in fiscal capacity reveal the degree of fiscal disparity within the nation. The fiscal gap at capacity, or the difference between revenue capacity and expenditure need, measures how much larger revenue effort would need to be to meet the 
expenditure needs of the state. This gap can be offset through transfers from federal governments or, if caused by short run disparities, through borrowing.

\section{Findings}

Connecticut ranks first with the highest representative revenue capacity of $\$ 6,272$ per person. In comparison, Mississippi, which ranks last, would raise only $\$ 3,352$ with the same revenue system in place. Alaska displays the highest representative revenue effort of all states, collecting $\$ 8,537$ compared with its capacity of $\$ 5,496 ;^{3}$ and New York had the second highest, collecting $\$ 6,376$ compared with its capacity of $\$ 5,240$. Although Tennessee expends the lowest revenue effort in dollar amounts, collecting $\$ 3,451$ compared with its capacity of $\$ 4,139$, New Hampshire actually demonstrates the lowest amount of revenue effort relative to its capacity-collecting only 76 percent of its revenue capacity of $\$ 5,482$ per person.

On spending, Mississippi has the highest expenditure need at $\$ 6,800$ per person, while Hawaii has the lowest at $\$ 5,216$. Alaska has by far the highest expenditure effort, spending $\$ 13,175$ per person, compared with a need of $\$ 5,995 ;{ }^{4}$ New York has the second highest expenditure effort, spending $\$ 8,414$ compared with a need of $\$ 6,052$. Meanwhile, Mississippi spent $\$ 5,365$ compared with its need of $\$ 6,800$. The top five states in terms of expenditure need-Mississippi, Louisiana, Arkansas, Alabama, and New Mexico-had, on average, 18 percent of their populations living in poverty compared with a national average of 11.5 percent.

Consistent with findings from previous years, the Mid-Atlantic and New England states enjoy the greatest revenue capacity (on a per capita basis). ${ }^{5}$ States in these regions also tend to have the lowest expenditure need, and thus rank among the top in terms of fiscal capacity. South Central states have the lowest revenue capacity, and relatively high expenditure needs. Therefore these states are, with few exceptions, at the bottom of the fiscal capacity rankings.

- In terms of tax capacity, ${ }^{6}$ comparing FY 2002 rankings to FY 1999 and FY 1997 shows that Delaware, Connecticut, Massachusetts, Wyoming, New Jersey, and Nevada have kept their places in the top ten. Alabama, Oklahoma, Arkansas, West Virginia, and Mississippi appear as the bottom five in all three years, albeit in varying orders.

- New York has consistently topped the tax effort rankings (Alaska has topped the revenue effort rankings even though it ranks low in tax effort because on a per capita basis it collected almost eight times the national average in nontax revenue sources, primarily through rents and royalties), while Nevada, Tennessee, South Dakota, and New Hampshire have remained relatively low-tax states.

- In terms of expenditure need, Alabama, Mississippi, New Mexico, Louisiana, and Texas appear at the top, and Iowa and New Hampshire at the bottom. FY 2002 rankings have given more emphasis to education expenditure needs for elementary school students and children in poverty than the 1999 and 1997 studies. This change in methodology moved some new states into the top ten, namely Arkansas (previously ranked 18th in FY 1999), West Virginia (previously 23rd) and South Carolina (previously 29th). 
- New Hampshire, Delaware, Connecticut, Massachusetts, Nevada and New Jersey kept their position in the top ten states with the highest fiscal capacity. Due in large part to an increase in energy prices, Alaska reappeared in the top ten in FY 2002, while Wyoming moved up to rank 11. (Alaska had ranked 26th in FY 1999 and Wyoming, 12th.) Alabama, Arkansas, Louisiana, Mississippi, New Mexico, Oklahoma, and West Virginia repeatedly appeared among the ten states with the lowest fiscal capacity during FY 2002, FY 1999, and FY 1997.

\section{Policy options}

The benchmarks used in these indices are simply the national averages; they are not proven optimal levels, nor are they necessarily desirable. It would be misleading to qualify aboveaverage index numbers as "excessive" or below-average index numbers as "deficient." Any policymaker seeking to make inferences based on these indices must remember that they measure the fiscal conditions of the states relative to the national average and not necessarily an optimal level.

At the same time, differences in state revenue capacity and expenditure need might justify federal intervention in terms of equalizing grants. Indeed, the federal government might view supplementing revenues for states with low fiscal capacity as part of its redistributive role, as a widely embraced goal of many nations possessing a federalist form of government is to narrow interstate or inter-provincial fiscal disparity.

We find little relation between the amount of federal aid received by states and their fiscal capacity - federal money is not primarily distributed to offset differences in the ability to raise revenues or provide services. While some federal grants are based on fiscally equalizing factors (for example, federal education funds related to the number of children in poverty), other programs require matching funds for states to be eligible for federal grants. Given the current level of federal funds allocated to state and local governments, 91 percent of the gap between revenue capacity and expenditure need across the states could be covered if federal funds were reallocated.

\section{Notes}

\footnotetext{
${ }^{1}$ The District of Columbia has been excluded from this study. D.C.'s characteristics resemble those of a municipality rather than a state; therefore, its results would not be comparable to those of other states. All "national" averages in this study are averages of the 50 states and exclude D.C. as well as other U.S. nonstate entities.

${ }^{2}$ Thus, when we refer to a state we mean the state and all local governments, including counties, municipalities, townships, special districts, and school districts.

${ }^{3}$ Care must be taken when including Alaska in comparisons because of its high dependence on natural resource (petroleum) taxes and rent and royalty payments. None of these revenue sources are borne by Alaska's residents.

${ }^{4}$ Alaska's high expenditures may reflect higher-than-average costs of providing, need for, or demand for public services; a significant amount of expenditures, however, is cash rebates to Alaskan residents. In FY 2002 , over $\$ 1$ billion (an average of $\$ 1,695$ per resident) was rebated through the Alaska Permanent Fund Dividend program (funded through oil windfalls). See http://www.pfd.state.ak.us/index.aspx for more information.
} 
${ }^{5}$ Comparisons across studies must be qualified since methodologies change over time. The report talks more on the issues surrounding such comparisons.

${ }^{6}$ Because the FY 1999 and FY 1997 studies did not include user charges and other non-tax revenue sources, it is not possible to compare revenue capacity and revenue effort estimates. 


\title{
Measuring Fiscal Disparities Across the U.S. States: \\ A Representative Revenue System/ Representative Expenditure System Approach, Fiscal Year 2002
}

\author{
NEPPC Working Paper 06-2 \\ A joint report with the Urban-Brookings Tax Policy Center \\ by Yesim Yilmaz, Sonya Hoo, Matthew Nagowski, \\ Kim Rueben, and Robert Tannenwald
}

\section{Introduction}

State and local government general revenues averaged $\$ 5,851$ per capita and ranged from $\$ 4,694$ per person in Arizona to $\$ 11,246$ in Alaska for FY 2002. ${ }^{1}$ General government spending ranged from $\$ 4,746$ for each resident in Arizona to $\$ 13,172$ for each Alaskan, according to the Census of Governments. These disparities reflect the different fiscal choices made by states out of either necessity or preference, as well as the ease of raising revenues due to underlying conditions. For example, Alaska's high revenues and expenditures reflect both the relatively painless cost to residents of raising revenues by taxing natural resources and the higher cost of providing services to a smaller and more remote population.

Over the long run, states and their local governments may choose to increase revenues or cut expenditures by promoting tax base growth or reducing long-term costs of public service delivery. In the short run, however, states have fewer options. To be sure, they can raise tax rates or cut programs to balance their budgets. However, cost savings or increases in revenues are limited by the underlying economic and demographic conditions present in the state. 
This report examines the states' fiscal capacity, or their potential ability to raise revenues relative to their need for public service expenditures. ${ }^{2}$ We consider a state's fiscal capacity to encompass the revenue-raising ability and expenditure needs of both the state and the local governments found within the state. Because states differ in terms of which level of government collects each type of revenue or provides each service, meaningful comparisons across states are only possible at this level of aggregation. We use the term "state" to refer to this combination of a state and its local governments in the remainder of the report. We use the representative revenue system (RRS) framework to estimate a state's potential revenue raising ability, or revenue capacity. In applying this framework (explained in more detail in the following section), we estimate how much revenue a state and its local governments would raise from commonly used state and local taxes, fees, and charges were they to impose the nationwide average effective rate on the "potential" or "standard" base of each tax. A tax's standard base equals its hypothetical value in the absence of nonstandard exemptions, exclusions, deductions, and other tax preferences and tax relief items.

To measure a state's need for public expenditures, we use the representative expenditure system (RES) approach to measure expenditure need. This approach involves the following steps: First, one determines the per capita amount spent by U.S. state and local governments on each of several standard spending categories (e.g., highways and bridges, primary and secondary education, public safety). The sum of these per capita outlays is the "standard" nationwide level of state and local public services. Then one evaluates how each state's unique characteristics—economic, demographic, social, and geographic—affect spending per capita. 
The fiscal capacity of a state is its revenue capacity relative to its expenditure need. A state with low fiscal capacity has a relatively small revenue base, a relatively high need for expenditures, or, as is often the case, a combination of both.

Connecticut ranks first with the highest revenue capacity at $\$ 6,272$ per person. In comparison, Mississippi, ranked last, would raise only $\$ 3,352$ with the same revenue system in place. Alaska displays the highest revenue effort of all states, collecting $\$ 8,537$ compared with a capacity of $\$ 5,496$. However, care must be taken when including Alaska in comparisons because of its high dependence on natural resource revenues, or revenues not borne by its residents. After Alaska, New York exerts the most amount of revenue effortraising 22 percent more funds than its underlying level of revenue capacity.

Although Tennessee expends the lowest revenue effort in dollar amounts (collecting $\$ 3,451$ compared with a capacity of $\$ 4,139$ ), New Hampshire actually demonstrates the lowest amount of revenue effort relative to its capacity—collecting only 76 percent of its revenue capacity of $\$ 5,482$ per person.

Mississippi had the highest expenditure need at $\$ 6,800$ per person, while Hawaii had the lowest expenditure need at $\$ 5,216$. Alaska had by far the highest expenditure effort, spending $\$ 13,175$ per person, compared with a need of $\$ 5,995,{ }^{3}$ while Mississippi spent $\$ 5,365$ compared with its need of $\$ 6,800$. The top five states in terms of expenditure need Mississippi, Louisiana, Arkansas, Alabama, and New Mexico - had, on average, 18 percent of their populations living in poverty compared with a national average of 11.5 percent.

Low fiscal capacity does not necessarily imply an unbalanced fiscal position; a state can be fiscally sound if it is covering any shortfall through federal transfers or grants, or (in the short run) debt issuance. But low fiscal capacity generally points to some vulnerability, 
typically in low service levels, high tax effort or, as we have seen in the case of Hurricane Katrina, less ability to cope with shocks to the economy. Louisiana, Mississippi, and Alabama -the three states hit hardest by Katrina- are among the states with the lowest revenue capacity (in the bottom six for FY 2002), highest expenditure need (top four), and lowest fiscal capacity (bottom five).

\section{A little history}

Starting in the Great Depression, formulas for allocating federal grants to state and local governments in the United States have tried to control for different needs across states. That is, grants were not distributed equally but incorporated some additional measure that took into account both a state's need for public services and its ability to raise revenues. This measure was referred to as fiscal capacity. Other countries with regional governments also use fiscal capacity measures; for example Canada has used a fiscal capacity measure in its federal-provincial equalization system since $1957 .{ }^{4}$ Strictly speaking, fiscal capacity is the potential ability of states to raise own-source revenue relative to the cost of service provision in that state. ${ }^{5}$ Before 1962 , the measure most used in the United States to represent fiscal capacity was per capita personal income. ${ }^{6}$ Controversy existed over this measure's validity as an indicator of revenue-raising ability. Two objections were raised: personal income fails to reflect the diversity of existing state tax and revenue sources, and it fails to take into account the ability of states to "export" taxes.

In 1962, two economists (Selma Mushkin and Alice Rivlin) at the U.S. Advisory Commission on Intergovernmental Relations (ACIR) published a report detailing the representative tax system (RTS) as an improved measure of fiscal capacity. The RTS was 
essentially the average tax system of all the states applied to each state's potential tax base. A state's total "tax capacity" divided by its population was the measure of fiscal capacity. While complex in its calculations, the RTS better reflected the ability of states to raise revenues and made possible analysis of different revenue sources.

In 1986, the ACIR introduced an expansion of the RTS—-the representative revenue system (RRS). The RRS included nontax revenues such as rents and royalties, user charges, and lottery revenues. The terminology changed accordingly, and the fiscal capacity measure became a state's "revenue capacity" divided by its population.

Analysts began to question the assumption that the cost of service provision could be proxied by a state's population without taking into account differences in income level or demographics. Accordingly, in 1990 the ACIR and Robert Rafuse developed the representative expenditure system (RES) to model more accurately the cost of providing public services in each state. Previously, fiscal capacity measures only took into account per capita considerations when assessing revenue and expenditure levels. At the time, a growing number of analysts were challenging the assumption that the service needs of a state's governments depend only on the total population in the state. As a result, Rafuse's system addressed the "neglected dimension of fiscal capacity." The RES features "workload factors" for each category of public expenditure (such as elementary and secondary education or public welfare). Thus, states with a relatively high population of school-age children or more people in poverty would have a higher expenditure need in the categories of elementary and secondary education and public welfare, respectively. The RES also incorporates an input-cost index, which accounts for price differences across states. 
In all, ACIR produced 12 reports from 1962 to 1993. After ACIR was disbanded, Robert Tannenwald at the Boston Federal Reserve took over the project and published reports approximately every two years in the remainder of the 1990s. He also changed the terminology: fiscal capacity, a term used somewhat interchangeably to describe tax or revenue capacity and the comparison of RTS or RRS and RES, was changed to fiscal comfort to avoid potential confusion. In this report, we have reverted to the original use of fiscal capacity to reflect international consensus about this term. We use "fiscal capacity" to refer to the ratio between tax/revenue capacity and expenditure need. ${ }^{7}$

This study reviews the basic concepts and methodology used and presents the state scores and rankings for revenue capacity, revenue effort, tax capacity, tax effort, expenditure need, and expenditure effort for FY 2002. We then combine measures concerning revenues and expenditures to measure fiscal disparities between states and create a measure of fiscal capacity and calculate the fiscal gap at capacity. Also included is an appendix with a glossary of terms; a detailed description of the RRS, RTS, and RES frameworks; and the sources and methods used in constructing the required data series for the study. The entire dataset is available for download at the Tax Policy Center and the Federal Reserve Bank of Boston's New England Public Policy Center web sites or can be requested from the authors. ${ }^{8}$

This is the first such study undertaken by the Tax Policy Center in collaboration with the New England Public Policy Center at the Federal Reserve Bank of Boston. 


\section{Basic concepts and methodology}

\section{Representative revenue system (RRS)}

As noted in the previous section, revenue capacity is the total amount of revenues that a state (and its localities) would have raised if it were to levy a set of taxes, charges, and fees that represented the average of all states' taxes, charges, and fees. Revenue capacity allows us to compare states' abilities to raise revenues independent of the policies actually implemented in each state. The representative revenue system (RRS) is the collection of information needed to calculate revenue capacity. Table 1 shows the 23 revenue sources used in this study, including general and selective sales items, license fees and taxes, personal and corporate income taxes, taxes on property, lottery revenues, general charges, ${ }^{9}$ and two additional categories covering all remaining tax and nontax revenues. ${ }^{10}$ In the past, some reports have looked at only tax revenues. Correspondingly, the framework was called the representative tax system (RTS) and calculated tax capacity instead of revenue capacity. RTS measures have been included as needed for comparisons with past reports.

For each revenue item, the standard base is the base that is potentially taxable; it includes the value (or volume) of all economic stocks or flows that the state and local governments would have been able to tax, levy charges on, or raise revenues from in the absence of nonstandard exemptions, exclusions, deductions, and other tax preferences and tax relief items. It is important to note that the determination of what should be included in the standard base for each revenue source is subjective. Generally, long-standing exemptions required by political, legal, or administrative necessities (for example, personal exemptions in income taxes or exclusion of business services from the sales taxes) are taken 
out of the standard base, while incentives or breaks intended to elicit certain behaviors or relieve particular constituents are left in the base (Tannenwald 1998). ${ }^{11}$

For each revenue item, the representative rate is the average effective rate of revenue collection (tax rate or charge/fee schedule) that prevails across the nation. The representative rate is calculated by dividing the national actual revenue collections by the national standard base for each revenue item. For example, in fiscal year 2002, state and local government tax collections for the personal income tax totaled $\$ 202$ billion for all 50 states, while the standard base was $\$ 6$ trillion (table 1). It is important to stress that the use of these standard measures is based on national averages and does not reflect a normative decision on what the proper size of government is or what the optimal tax rate on a given item or economic activity should be.

Revenue capacity for each state is calculated by applying the representative rate to the standard base for each item and adding all the revenue item capacities. Finding the relative position of each state compared with the national average revenue capacity creates an index of revenue capacity by which states can be compared.

Taxes are generally the largest source of revenue for state and local government, and a state with a large stock of wealth or economic flow in traditionally taxed areas has a large revenue capacity (Tannenwald and Turner 2004). As evident from table 1, general sales, personal income, and property taxes accounted for more than half of state and local revenue collections in FY 2002. ${ }^{12}$ Consequently, states with high per capita income and high property values tend to have high revenue capacity. Severance taxes, or extraction taxes on natural resources, are relatively small sources of revenue in aggregate (see table 1). However, because natural resources are concentrated, a few natural resource-rich states (for 
example, Alaska and Wyoming) rank high in terms of their revenue capacity owing to the large amount of revenues they can obtain from these resources. States collected approximately 20 percent of their revenues from user charges and fees (for example, school fees and tuition, hospital charges, transportation fees, toll collections, parking revenue, and others), and 11 percent from nontax items such as sale of property and interest income.

By comparing a state's actual revenues to its revenue capacity, we can derive a measure of revenue effort. States with high revenue effort take in more revenues than they would under the representative system. Ranking each state's revenue effort relative to the national average creates the index of revenue effort. This measure reveals how intensively each state raises revenues—-both within each tax or revenue category, and in total revenues relative to the national average. Box 1 presents a step-by-step description of the calculations of revenue capacity and revenue effort.

\section{Box 1. Calculating revenue capacity and revenue effort with selected examples}

Step 1. Collect data on revenues received by each state (and its localities) for each of the bases in the representative revenue system.

Step 2. Construct the standard base for revenue source in each state, including all sources that could be potentially taxed (or incur charges/fees). (See appendix on RRS methodology on the base calculations.)

Step 3. Compute the representative rate for each revenue base, by dividing total nationwide collections by the national total base for that revenue item. This creates the representative revenue system (table 1 ).

Step 4. Apply each representative rate to the corresponding revenue item in every state. This determines the hypothetical revenue capacity if every state used the representative system as its revenue-raising system. 
Step 5. Add together the hypothetical revenue yields from each revenue source in each state to obtain the total revenue capacity in each state.

\section{Selected examples 2002 total revenue capacity}

$\begin{array}{lr}\text { U.S. (all 50 states) } & \$ 1,338,934 \text { million } \\ \text { New York } & \$ 100,351 \text { million } \\ \text { Texas } & \$ 92,786 \text { million } \\ \text { Virginia } & \$ 34,550 \text { million }\end{array}$

Step 6. Divide total revenue capacity in each state by its population to determine per capita capacity.

$\begin{array}{lrc}\text { Selected examples } & 2002 \text { population } & 2002 \text { per capita capacity } \\ \text { U.S. } & 287.38 \text { million } & \$ 4,659 \\ \text { New York } & 19.15 \text { million } & \$ 5,240 \\ \text { Texas } & 21.72 \text { million } & \$ 4,271 \\ \text { Virginia } & 7.27 \text { million } & \$ 4,750\end{array}$

Step 7. Divide each state's per capita capacity by the national capacity collections and multiply by 100 . The result is the revenue capacity index, with an index number of 100 corresponding to the national average.

\section{Selected examples Index calculation Index number Revenue capacity rank}

$\begin{array}{llrl}\text { U.S. } & \text { NA } & 100 & \cdot \\ \text { New York } & (5,240 / 4,659) \cdot 100 & 112 & 9 \\ \text { Texas } & (4,271 / 4,659) \cdot 100 & 92 & 33 \\ \text { Virginia } & (4,750 / 4,659) \cdot 100 & 102 & 17\end{array}$

Step 8. Divide each state's actual revenue collections by the state's population to get collections per capita.

\section{Selected examples Total revenues Per capita revenues}

U.S.

New York

Texas

Virginia
$\$ 1,338,934$ million

$\$ 122,107$ million

$\$ 87,273$ million

$\$ 33,138$ million
$\$ 4,659$

$\$ 6,376$

$\$ 4,017$

$\$ 4,556$ 
Step 9. To calculate revenue effort, divide each state's per capita collections by its per capita capacity and multiply by 100 .

\section{Selected examples}

U.S.

New York

Texas

Virginia

\section{Index calculation Index number}

NA

$(6,376 / 5,240) \cdot 100$

$(4,017 / 4,271) \cdot 100$

$(4,556 / 4,750) \cdot 100$
100

122

94

96

\section{Revenue effort rank}

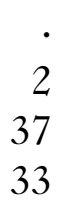

Sources: ACIR and authors' calculations.

\section{Representative expenditure system (RES)}

A state with a high revenue capacity and high revenue effort may still be in a fiscally weak position if it also has high expenditure need. Expenditure need measures how much a state must spend per capita on its residents to provide the basic services typically offered by state and local governments across the country. While it is the conceptual analog to revenue capacity, expenditure need involves more complex calculations. To do so, one must answer the following questions: First, what standard mix of public services do state and local governments typically offer? Second, what constitutes a standard level of services for each expenditure item in this mix? Third, what would each state and its municipalities have to spend, in per capita terms, to provide this standard set and level of services?

The standard array of services are services typically provided by state and local governments, evidenced by their inclusion as a large category in the Census of Governments. This study includes six such functions—-basic (K-12) education, higher education, public welfare, health and hospitals, highways, and police and corrections-that constituted 71 percent of all direct general expenditures for state and local governments in FY 2002 (see box 2 for more detail). ${ }^{13}$ A lump-sum category of "other" expenditures covers 
environment and housing, interest on general debt, governmental administration, and all other direct general expenditures. The standard level of services is the nationwide average of the per capita spending for the provision of these services. The representative expenditure system $(R E S)$ is the collection of per capita average expenditures that prevail in the entire nation over this standard bundle of services. Again, we must stress that the level of services estimated represents the national average, but does not reflect a normative measure of the optimal level of services.

\section{Box 2. What functions are in the expenditure need calculation?}

Elementary and secondary education: Includes expenditures associated with the operation, maintenance, and construction of public schools and facilities for elementary and secondary education (kindergarten through high school), vocational-technical education, and other educational institutions except those for higher education, whether operated by independent governments (school districts) or as integral agencies of state, county, municipal, or township governments; and financial support of public elementary and secondary schools.

Higher education: Includes expenditures associated with operating higher education institutions and auxiliary enterprises connected to those institutions.

Public welfare: Includes federal and local cash assistance payments such as Supplemental Security Income and Temporary Assistance for Needy Families (TANF), intergovernmental aid under the federal Medicaid program and cash payments made directly to individuals, contingent upon their need. It also includes vendor payments under public welfare programs made directly to private vendors for medical assistance and hospital or health care, including Medicaid (Title XIX), on behalf of low-income or other medically needy persons unable to purchase such care. Provision, construction, and maintenance of nursing homes and welfare institutions owned and operated by a government for the benefit of veterans or needy persons and public employment for all public welfare activities and expenditures for welfare activities not classified elsewhere are also accounted for in this category.

Hospitals: Includes expenditures associated with the maintenance of hospital facilities directly administered by the government and provision of care at other hospitals, public or private. 
Highways: Includes expenditures associated with the maintenance, operation, repair, and construction of toll and non-toll highways, streets, roads, alleys, sidewalks, bridges, tunnels, ferry boats, viaducts, and related structures.

Police protection and corrections: Includes expenditures associated with the preservation of law and order, protection of persons and property from illegal acts, and the prevention, control, investigation, and reduction of crime and expenditures associated with institutions or facilities for the confinement, correction, and rehabilitation of convicted adults or juveniles adjudicated delinquent or in need of supervision, and for the detention of adults and juveniles charged with a crime and awaiting trial.

Other: Includes environment and housing (expenditures associated with the development and conservation of natural resources, parks and recreation, housing and community development, and the provision, maintenance and operation of sanitation services); government administration (expenditures associated with the provision, maintenance, and operation of government finances, judicial, legal, and legislative institutions, public buildings, and other staff services) and interest on general debt (amounts paid for use of borrowed monies, excluding utility debt, paid by all funds of the government).

Source: Government Finance and Employment Classification Manual, http://www.census.gov/govs/www/class.html.

Note: The expenditure figures used in this study include all direct state and local general expenditures. They exclude all direct federal and intergovernmental expenditures (but include, for instance, money that is spent as part of federal grants to states, or state grants to local municipalities).

To determine how much each state and its localities must spend to finance this standard mix and level of services, we must account for demographic, socioeconomic, and even geographic characteristics that would affect a state's needs. The characteristics used in estimating relative expenditure needs are called the workload factors. These factors help reallocate the total nationwide expenditures for a given function across states in proportion to each state's needs. For example, the number of people in poverty in a given state (in proportion to the total population in poverty in the entire nation) is part of the workload factor used in calculating the state's needs for welfare expenditures—-the higher the state's 
share of people in poverty in the national total compared to its share of the overall population, the more money the state needs out of the national public welfare expenditure pool. As one can see from this example, the workload factors do not take into account a state's preference for or ability to fund public services, and therefore they are a policyneutral way of analyzing expenditure need.

After calculating expenditure need using the workload factors, we must still account for differences across states in the cost of providing public services. This study uses an input-cost index (calculated for each state based on the prevalent labor costs in the state) to adjust the expenditure estimates. The methodology behind the input-cost index is explained in appendix C. The input-cost-adjusted expenditure need for each state is used to calculate the index of expenditure need, which ranks states' per capita expenditure needs with respect to the representative expenditures. Box 3 provides a step-by-step description of how the representative expenditure system and the index of expenditure need are calculated.

Because education and public welfare account for almost half of state and local expenditures, the relevant workload factors, particularly the share of school-age children in the population and the poverty rate in states, play a large role in the determination of need. In fact, the share of total expenditure needs in these two categories can explain 87 percent of the variation in the index for expenditure need. ${ }^{14}$ For example, in Texas, the relatively large size of the school-age cohort likely to attend public schools, coupled with high child poverty rates (22 percent compared with 17 percent nationally) increases the need for education expenditure. 
A measure of states' service provisions (that is similar to revenue effort in concept) is the ratio of actual expenditures to the estimated expenditure need for a given state. By comparing the actual expenditures to the expenditure needs (which are already adjusted for demographic variations and variations in input costs), we build an index of expenditure effort to pinpoint states that spend under and over what we expect them to spend based on a nationally representative set of expenditure policies. Comparing actual expenditures to expenditure need could highlight state and local governments' efficiency (or inefficiency) in service provision (controlling for service level), and the differences in voters' demands for public services. ${ }^{15}$ Because of balanced budget rules in place in 49 of the 50 states, limited expenditure effort could also be indicative of low revenue capacity—that is, both sides of government budgets must balance, so for a state with low revenue capacity meeting high expenditure needs will entail higher tax rates in place. We consider the connection between revenues and expenditures further in the next section.

\section{Box 3. Calculating expenditure need}

Step 1. Determine basic expenditure functions to be included in the study. The list must include expenditure items common to all state (including local) governments. This study works with six such factors (in addition to one lump sum "other" category): K-12 education, higher education, public welfare, health and hospitals, highways, and police and corrections. In FY 2002, these categories accounted for 71 percent of all direct general expenditures for state and local governments.

Step 2. For each expenditure item, identify workload factors that will determine the relative need across states. These workload factors generally include socioeconomic, demographic, and geographic characteristics not directly influenced by state policies, at least in the intermediate run. For example, for secondary education, the workload factor used is the number of secondary school-age children and the proportion of children in poverty. 
Step 3. Because the focus is on relative need, express each state's workload factor as a percentage of the national workload factor. Below are the workload factors for K-12 education (which include the number of school-age children and the number of children in poverty), higher education (which include the cohorts above age 14) and welfare (which use the population living in poverty):

$\begin{array}{lccr}\text { Workload factor for } & \text { K-12 education } & \text { Higher education } & \text { Welfare } \\ \text { U.S. } & 100.00 \% & 100.00 \% & 100.00 \% \\ \text { New York } & 6.12 \% & 6.61 \% & 7.92 \% \\ \text { Texas } & 8.87 \% & 8.02 \% & 9.26 \% \\ \text { Virginia } & 2.42 \% & 2.38 \% & 1.97 \%\end{array}$

Step 4. Compute an input-cost index to account for the differences in the cost of providing services across states (See appendix C on RES methodology for details). The index should reflect variations in input costs across states and take into consideration all sources of compensation (payroll and non-payroll).

$\begin{array}{lccr}\text { Input-cost index for } & \text { K-12 education } & \text { Higher education } & \text { Welfare } \\ \text { U.S. } & 100.00 \% & 100.00 \% & 100.00 \% \\ \text { New York } & 103.16 \% & 102.91 \% & 100.43 \% \\ \text { Texas } & 99.12 \% & 99.19 \% & 99.88 \% \\ \text { Virginia } & 102.58 \% & 102.37 \% & 100.35 \%\end{array}$

Step 5. For each expenditure function, multiply the national total direct general expenditure with each state's workload factor to estimate expenditure need. Then, adjust the expenditure need for the cost of service provision for each state. Normalize this figure so that the total national expenditure need for each item equals the actual national expenditures. Divide this number by the state's population to calculate the per capita expenditure need.

\begin{tabular}{lccc}
\multicolumn{2}{l}{ Per capita expenditure need: } & K-12 education & Higher education \\
Welfare & & \\
U.S. & $\$ 1,427$ & $\$ 545$ & $\$ 973$ \\
New York & $\$ 1,351$ & $\$ 557$ & $\$ 1,162$ \\
Texas & $\$ 1,659$ & $\$ 574$ & $\$ 1,191$ \\
Virginia & $\$ 1,397$ & $\$ 524$ & $\$ 759$
\end{tabular}


Step 6. For each state, sum up the per capita expenditure need calculations across all expenditure items.

Selected examples Per capita expenditure need

U.S. $\quad \$ 6,007$

New York \$6,052

Texas \$ \$6,496

Virginia $\$ 5,764$

Step 7: Index each state's expenditure need to the national average to calculate the index of expenditure need.

\section{Selected examples}

U.S.

New York

Texas

Virginia

\section{Expenditure need index Rank \\ 100}

$101 \quad 19$

$107-6$

\section{Fiscal capacity}

A state's fiscal capacity is its tax capacity relative to its expenditure need. ${ }^{16}$ The index

of fiscal capacity ranks states in terms of their fiscal ability relative to the national average, and gives a sense of each state's ability to fund its expenditure needs through its own resources. A state with low fiscal capacity has a relatively small revenue capacity, a relatively high need for expenditures, or a combination of both. Although such a state may be able to fill in the gap between revenues and expenditures through federal grants, it is also likely that states with low fiscal capacity are in relatively weak fiscal positions that may result in poor service levels or reduced ability to cope with economic shocks. We will consider these disparities in fiscal capacity levels between states in more detail below.

A state's fiscal gap is the difference between actual revenues and expenditures. The fiscal gap at capacity is the difference between revenue capacity and expenditure need. That 
is, it measures whether a state can meet a goal of providing our standard set of government services with average tax rates and charges in place.

Differences in fiscal disparity (as measured by differences in fiscal capacity or fiscal gaps at capacity) within the nation can be especially interesting to national policymakers, since a widely embraced goal of many nations possessing a federalist form of government is to narrow interstate or inter-provincial fiscal disparity. Concern about fiscal disparity rests primarily on two interrelated normative considerations. First, access to some minimum level of state and local public services is desirable. Second, as long as fiscal disparity exists, residents of states with higher fiscal capacity bear a lower tax burden to obtain this minimum than residents in states with lower fiscal capacity. Moreover, these differences exacerbate fiscal disparity over the long run by trapping fiscally stressed states in a vicious circle. The more intensively they tax, the more they might drive away capital and labor, the more fiscally stressed they become, the more they must raise tax burdens to provide the minimum level of desired services, and so on. What this minimum level of service is would be a normative choice and is not equal to the rates used in this study. However, rank ordering of states by differences between revenue capacity and expenditure need would be similar no matter what representative tax and expenditure rates are chosen.

\section{Box 4. Alternative measures of fiscal capacity: Actual revenues, personal income, state gross product, and total taxable resources}

The fiscal capacity of a state is its ability to raise own-source revenues through state and local government taxes, fees and charges relative to its need for public services. The representative approach used in this report narrowly defines the two components of fiscal capacity-revenue capacity and expenditure need-as hypothetical revenue collections and expenditures a state would have realized had it followed the average revenue and expenditure policies that prevail across the nation. However, given the amount of data 
collection and calculations required of the representative approach, policymakers often seek alternative measures of fiscal capacity.

Actual revenues. The crudest measure of revenue capacity is a state's current tax or revenue collections. Although simple to compile, actual revenues are a poor proxy of the state's ability to raise own-source revenues because revenue policies and tax enforcement efforts vary considerably.

Personal income. An alternative measure of revenue capacity, commonly used in calculations of a state's "tax burden," is the personal income of the state. But this measure is an incomplete proxy; personal income is one among many sources of revenue for the state. A state's revenue capacity also depends on its ability to "export" its taxes—shift its tax burden to nonresidents by taxing economic resources or rents outside its jurisdiction.

Gross state product (GSP). Gross state product - the total values of goods and services produced by a state's economic resources-is sometimes used as a measure of fiscal capacity to account for the ability to export taxes. Like personal income, a state's gross product encompasses all the income earned by its population, but also includes income generated within the state without regard to the location of the entity receiving the income. Compared to personal income, GSP better reflects the total amount of economic activity potentially subject to taxation by a state, but does not include the income earned by its residents from out-of-state sources, which is a source of income that may be-but is not often-taxed by states.

Total taxable resources (TTR). The U.S. Department of Treasury has adopted a method known as total taxable resources as the official measure of states' revenue capacities. TTR adds to GSP the income earned from out-of- state sources and direct federal transfer payments (e.g. unemployment insurance, social security), while subtracting certain indirect federal taxes and contributions to social insurance programs.

An underlying concern in all these measures of fiscal capacity is that they present a onedimensional perspective of a state and local government's ability to raise revenue. In other words, they consider all potential revenue bases in a state equally valid sources of revenue. Subject to prevailing norms, however, different revenue bases are subject to different levels of taxation across the states; as a result, some bases are more plausible sources of revenue than others.

In addition, the above measures have traditionally calculated the "needs" component of fiscal capacity through strict per capita comparisons, assuming that the demand for public service provision only depends on a state's population. This is a limitation to the abovementioned measures, as public expenditure levels often depend upon more narrowly defined segments of a state's population or geography.

Compared with the representative approach, the alternate measures of fiscal capacity are easier to compile and compute, yet their generalized, more simplistic approach limits their 
usefulness. The RRS/RES methodology used by this report provides an exhaustive, dataintensive approach to understanding the fiscal capacity of a state and its local governments. By using disaggregated data and representative rates, policymakers are able to not only ascertain a state's relative level of fiscal capacity, but also draw out underlying levels of revenue and expenditure effort amidst various tax bases and spending categories.

\section{A note on interpreting the results}

The $R R S$ and $R E S$ frameworks provide a simple, yet powerful way of looking at interstate fiscal disparity. The frameworks have a number of advantages for policy makers and over alternative measures (see box 4). First, the revenue capacity, expenditure need, and fiscal capacity measures allow for a judgment on how states compare in their ability to finance expenditure needs from their own resources (on a per capita basis). Second, the measure of revenue effort (ratio of actual revenues to revenue capacity) across states gives a sense of the different policy choices that states have made. One can look at how a state's revenue effort varies across different revenue items to obtain further insight on various alternatives to the state's existing tax composition. Third, the measure of expenditure effort (ratio of actual expenditures to expenditure need) could help identify states that spend more or less than what we expect based on their demographic characteristics. Fourth, the $R R S$ combined with the $R E S$ give a sense of how intergovernmental grants could be allocated to offset shortfalls faced by states experiencing a high amount of fiscal hardshipspecifically highlighting states with low revenue capacity and high expenditure needs.

Nonetheless, some caveats on the interpretation of the results are in order. First, revenue capacity, expenditure need, and fiscal capacity are calculated through mechanical exercises repeated over an identical set of tax and expenditure items for each state. Thus, the 
estimations omit important variables related to administrative constraints, historical factors, institutional strengths or limitations, constituent preferences, and service provision limitations or inefficiencies that might shed light on why certain states rank the way they do. For example, a high measure of expenditure effort (actual expenditures to expenditure needs) tells us little about why a state spends more than the representative amount.

Additionally, the benchmarks used in indices are simply the national averages; they are not proven optimal levels, nor are they necessarily desirable. It would be misleading to qualify above-average index numbers as "excessive" or below-average index numbers as "deficient." Further, the RRS/RES framework is a static picture of prevailing policies in the nation, and the findings on their own are insufficient for fiscal policy recommendations (without restrictive assumptions on, for example, the elasticity of the revenue bases to the tax rates and user charges).

Lastly, although some results from past studies are included in the current report, intertemporal comparisons of these numbers should be made cautiously for two reasons. First, the methodologies used in the calculations of the revenue capacity and expenditure need numbers have changed from year to year. These changes have occurred as old data became unavailable or new data were made available, and as researchers improved calculations to better reflect changes in tax bases or service delivery. For instance, the FY 2002 report includes, in the revenue capacity calculation, nontax items such as net lottery revenues that were not included in the FY 1999 report, to reflect the increasing prevalence of these public revenue sources. We have also changed the factors underlying some expenditure categories to reflect a changing understanding of what affects the costs of provision of given services. 
On this point, the indices are relative measures and so changes in a state's index do not necessarily translate into real changes in their revenue capacity or expenditure need. For example, South Dakota received an index score of 96 in the tax capacity index for both FY 1999 and FY 2002. The correct way to interpret this score for both years is "South Dakota's tax capacity was slightly below the national average in FY 1999 and FY 2002," and not "South Dakota maintained the same tax capacity." In fact, South Dakota experienced a slight decline in its tax capacity from $\$ 3,090$ in FY 1999 to $\$ 3,049$ (both in 2002 dollars). Since other states also experienced a decrease in their tax capacity, South Dakota maintained its relative position. Given these problems in intertemporal comparisons, we only look at large movements in state rankings as informative on a state's relative performance. The results are discussed in the next section.

\section{RRS and RES results for FY 2002}

\section{Representative revenue system}

Table 2 displays the revenue capacity and revenue effort indices and state rankings for the 50 states for FY 2002. The average revenue capacity is $\$ 4,659$. Connecticut ranks highest with a revenue capacity of $\$ 6,272$ and a revenue capacity index of 135 , while Mississippi has the lowest revenue capacity at $\$ 3,352$ and an index of 72 . Alaska shows the highest revenue effort of all states, collecting $\$ 8,537$ compared with its capacity of $\$ 5,496$, while New Hampshire displays the lowest effort, collecting $\$ 5,482$ to its capacity of $\$ 4,142$. Again, part of Alaska's revenue effort reflects a transfer of payments to its residents; that is, Alaska is able to export more than 100 percent of the revenue burden needed to govern the state and to raise revenues that are then remitted to residents. 
In 2002, revenue capacity correlated strongly with high average household incomes (Mid-Atlantic and New England states), ${ }^{17}$ high property values (California, Colorado), and availability of large energy resources (Alaska, Wyoming). Other states have specific sources of well-cultivated revenue; Nevada's high tax capacity is largely due to gambling establishments, while Delaware—a corporate income tax haven—benefits from the high license fees it charges to companies incorporated within the state. Geographically, states in the central area of the country—especially the South Central states—lag behind other regions and the national average (figure 1). These patterns mirror the results from past years.

Appendix table D2 presents the revenue and tax capacity results for various years. Because the FY 1999 study did not include nontax revenues, we look at the changes in the tax capacity index over the past few years to compare over time differences. Between FY 1999 and FY 2002, 14 states moved by six or more positions in tax capacity rankings. The most significant moves were by Kentucky, which moved from 44 to 30; Arizona, which moved from 25 to 37; and Rhode Island, which moved from 39 to 28. Increasing energy prices helped Alaska, Colorado, and Wyoming climb up in tax capacity rankings, while Hawaii continued to drop in the rankings as its tourism revenues remained stagnant.

Revenue effort results show fewer regional trends. Mid-Atlantic states show higher revenue effort than other regions (figure 2). Again, because the FY 1999 study did not calculate revenue effort, we are only able to look at changes in tax effort between 1999 and 2002 (see appendix table D3). Among the states that showed the largest swings in tax effort, Massachusetts, Colorado, and Idaho moved down in the rankings as their property tax rates (averaged across all types of property) went down. Texas, together with Wyoming and 
Nebraska, moved up in the rankings, even though its severance revenues (and oil production) fell significantly from 1999 to $2002 .{ }^{18}$

It is worth noting that a high revenue effort index score does not necessarily mean that a state's residents experience relatively high taxes or charges. Some revenue sources are not effectively captured in the representative system, particularly for natural resourcerich states that rely more heavily on interest revenue and other revenues stemming from their natural resources. Thus, the high revenue effort seen for Alaska and Wyoming may actually stem from an underestimation of their revenue capacities.

\section{Representative expenditure system}

Table 3 presents the expenditure need and expenditure effort indices for FY 2002.

Mississippi had the highest expenditure need at $\$ 6,800$ per person, giving it an expenditure need relative rating of 113 , while Hawaii had the lowest expenditure need at $\$ 5,216$ with an index of 87 . Alaska had by far the highest expenditure effort index at 220, spending $\$ 13,175$ per person compared with a need of $\$ 5,995$, while Arkansas had the lowest index at 74 , spending $\$ 4,827$ compared with its need of $\$ 6,539$.

States with high expenditure needs are generally those with a combination of high poverty rates, a large primary and secondary school-age cohort (age 5 through 17), and high crime rates. Southern Central states had the highest expenditure need while index scores for the Mid-Atlantic, New England, North Central, and Pacific states were below average (figure 3). The top five states in terms of expenditure need-Mississippi, Louisiana, Arkansas, Alabama, and New Mexico—had, on average, 25 percent of their population under age 18 living in poverty (the average across the United States is 16.5 percent). Moreover, these same five states collectively accounted for over 9 percent of the capital 
crime in the entire nation while their population accounted for 6 percent of the U.S. population.

Some changes from FY 1999 to FY 2002 can be attributed to methodological updates made in the calculation of secondary education and public welfare expenditure need. Previous iterations of this study used Robert Rafuse's original assumptions that the primary to secondary per pupil cost ratio is 0.60 and children in poverty cost 25 percent more to educate. The per pupil costs at the primary level have been increasing over the past decade—from 1999 to 2005 , this ratio climbed from 0.79 to $0.86 .{ }^{19}$ For this report, we assume that the cost ratio is 0.85 . We also adjust the additional costs required to educate children in poverty from 25 percent to 50 percent. This percentage better accounts for the costs of compensatory education, special education, language education programs, and supplemental services, as well as the other costs related to operating a school in a poor area such as transportation, school lunch, theft, and vandalism (Rothstein 2001).

The other methodological change is in the public welfare calculation, which now incorporates the percentage of the elderly (above 75 years) that live in poverty into the workload measure. This change was made because Medicaid expenditures for long-term care constitute a significant portion of the state welfare expenditures and the elderly/poor population in each state is a good proxy for measuring the need for such expenditures. Previous methodologies only considered the percentage of a state's population in poverty. ${ }^{20}$

The measure of expenditure effort—comparison of actual per capita expenditures against the expenditure need-is a new addition to the RES framework in the FY 2002 study. Pacific, Mid-Atlantic, and New England states generally spend more than their 
expenditure need measure predicts, whereas South Central states typically spend less than their "need" estimates (figure 4).

Comparing the expenditure effort to expenditure need, one sees that the relation between actual expenditures and expenditure need is not necessarily strong. ${ }^{21}$ Alaska, the top spender in the list, ranks 21st in the index of expenditure need, whereas Arkansas, which ranks third in the expenditure need index, is last in the expenditure effort rankings. On the other hand, a strong, positive relationship exists between expenditure effort and revenue capacity_-states with above-average revenue capacities tend to spend relatively more than their expenditure need would indicate (figure 5). These states also tend to have above-average revenue efforts (the correlation between revenue effort and expenditure effort is 0.63 ).

\section{Fiscal capacity in FY 2002}

Following Tannenwald (1998), we construct a measure of fiscal capacity (previously called "fiscal comfort" by Tannenwald) for each state by dividing the state's revenue capacity index number by its score on the expenditure need index. Table 4 presents the results and the rankings for FY 2002. A high measure of fiscal capacity signals that a state has a large "representative" revenue base relative to a "standard" level of expenditures. Conversely, if a state has a low measure of fiscal capacity, the measure indicates that the state has a high amount of "standard" expenditure need relative to its "representative" revenue base. Because revenue capacity and expenditure need are strongly and negatively correlated (figure 6), with few exceptions, the rankings for the fiscal capacity index closely resemble the rankings for revenue capacity. The Mid-Atlantic, New England, and Pacific 
states place near the top of the distribution, while the South Central states settle near the bottom.

As mentioned before, the FY 2002 study finds a strong, negative correlation between revenue capacity and expenditure need (figure 7). In other words, the neediest states also have the least amount of own resources available to them. The correlation coefficient for the two index numbers is -0.57 -in other words, 33 percent of the variation in either of these two indices is predicted by variation in the other index. Further, similar relationships exist between these two statistics in both the FY 1997 and FY 1999 studies.

Could states with high expenditure needs meet these needs by increasing revenue effort? Comparing the fiscal capacity index with the revenue effort index shows that states in relatively weak fiscal positions are wary of raising tax rates (figure 8). This could be due to fear that aggressive taxing may only exacerbate fiscal disparities by driving away the tax base. Tannenwald and Turner (2004) note that variation in preferences for public services may be inferred from the correlation between state tax effort and fiscal capacity. If all states desired a uniform level of services, then states with low fiscal capacity would have to tax their bases relatively intensely or exhibit high tax effort to provide the desired level of services. In contrast, a state with high fiscal capacity could have a relatively low tax effort and still provide the desired level of services. We find that some states with relatively high fiscal capacity are providing higher levels of services—spending more rather than lowering tax rates. Meanwhile, some states with low fiscal capacity rankings have high and others have low revenue effort rankings. This suggests that states are making different decisions on what trade-offs to make between spending and revenues. 


\section{Closing the fiscal gap: Federal intergovernmental transfers}

While the fiscal capacity measure looks at the share of the per capita expenditure needs a state could cover through its own resources assuming a standardized level of tax rates and service provision, another way of measuring the potential mismatch between revenues and expenditures is to measure the fiscal gap at capacity-the difference between revenue capacity and expenditure need that a state would have faced had it followed the representative revenue and expenditure model. The gap at capacity standardizes away from policy decisions and looks at underlying structural fiscal imbalance. In effect, if everyone were raising revenue at the same effort and providing services at the same levels, which states would still have a gap? Would federal aid close the gap? At its current level, could federal aid close the gap if it were reallocated?

During FY 2002, states raised $\$ 1.68$ trillion in general revenues ( $\$ 358$ billion of which was generated through federal transfers) and spent $\$ 1.73$ trillion in general expenditures. ${ }^{22}$ Table 5 examines how federal intergovernmental aid compares with our measures of actual and calculated fiscal gaps at capacity and asks how much federal transfers would have offset fiscal gap at capacity if states were to follow the representative tax and expenditure policies. That is, do federal transfers reflect this difference in ability to pay and expenditure need?

During FY 2002, the actual fiscal gap, or the difference between own-source revenues raised and expenditures, averaged $\$ 1,409$ per capita across the states. Each state received, on average, $\$ 1,331$ per capita from the federal government and faced a $\$ 78$ per capita shortfall after federal transfers. After accounting for federal transfers, 19 states had a 
negative fiscal gap after transfers — the ability to pay for all expenditures through a combination of own-source revenues and federal transfer payments.

What would happen to a state's fiscal gap if it were to follow the representative approach in setting its revenue and expenditure policies? Fiscal gap at capacity measures this hypothetical scenario. Some states (those that tend to have low revenue effort or higher expenditure effort) would realize an increase in their fiscal gap. Other states (those with high revenue effort or low expenditure effort) would experience a decline in their fiscal gap, and four states would be able to cover their expenditure needs completely through their own resources, without having to rely on intergovernmental transfers. These four states would have a negative fiscal gap at capacity or a fiscal surplus.

Actual federal government transfers to the states in FY 2002 would have been enough revenue to completely close any gap between the estimated revenue capacity and expenditure need calculated in 24 states (compared with 19 states that did not have an actual gap after accounting for federal transfers in FY 2002). Meanwhile, those states with large fiscal gaps at capacity would still face large fiscal gaps under the representative model, even after accounting for current federal transfers. Put another way, actual federal transfers could not close the fiscal gaps in all states if each state adopted representative revenue and expenditure policies.

The current allocation of federal money takes into account more than just each state's expenditure need. For instance, federal Medicaid money flows to the states not only on the basis of each state's expenditure need, but also under a matching program to encourage states to expand their coverage. States able to expend more from their own coffers will receive more from the federal government. As a result, no clear pattern exists in 
the relationship between the federal money that a state receives and its fiscal gap at capacity; the correlation between a state's fiscal gap at capacity and the amount of federal transfers that it receives is 0.10 (figure 9).

Would the federal government have been able to cover the fiscal gap at capacity for all states by reallocating its intergovernmental transfers? The total sum of fiscal gaps at capacity across the 46 "gap" states stood at $\$ 391$ billion in FY 2002. Given the $\$ 358$ billion of federal transfers to the states in FY 2002, the federal government could not have erased entirely the fiscal disparities that exist across the states simply by reallocating transfers among states. But a reallocation of federal funds could help lessen the gaps found; indeed, federal funds would have covered 91 percent of the hypothetical fiscal gap at capacity that exists across states. Thus, reallocating federal transfers could help close the fiscal gap at capacity. Federal transfer programs serve multiple purposes, however, and the lack of correlation between fiscal gaps at capacity and federal funds reflects the myriad of goals in place.

\section{Conclusion}

Fiscal disparities across states persisted in FY 2002. As the Mid-Atlantic and New England states continued to have the highest measures of fiscal capacity while exerting considerable revenue effort, the South Central states continued to be the lowest fiscal capacity states, with the lowest amount of revenue capacity combined with high levels of expenditure needs.

State revenue capacity and effort continue to correlate, and states with high revenue capacity tend to spend more per capita. The correlation between fiscal capacity and revenue 
effort across the states continues to remain insignificant in 2002, as does the correlation between actual expenditures and representative expenditure need. There is evidence of a negative correlation between revenue capacity and expenditure need; that is, the states with the highest representative level of need seem poorly positioned to raise required funds.

Differences in state revenue capacity and expenditure need might provide a justification for federal intervention in terms of equalizing grants. Indeed, the federal government may view supplementing revenues for states with low fiscal capacity as part of its redistributive role. But the decision to implement any equalization scheme must take into account that new funds might be used to offset existing spending programs or lead to overinvestment in certain expenditures based on a reduced price of providing services. Federal funds might also affect the responsiveness of tax bases to tax rates within each state depending on how funding programs are set up. In addition, we are measuring the aggregate level of revenue capacity and expenditure need faced by all governments within a state. Depending on individual structures found in specific states, the allocation of funds to states versus the local governments within the states might vary for specific transfer programs and spending areas.

Little correlation exists between the aggregate amount of federal aid received by states and their fiscal capacity—-that is, federal money is not primarily distributed to offset differences in the ability to raise revenues or provide services. While some federal grants are based on fiscally equalizing factors (for example, education funds related to the number of children in poverty), other programs require matching funds for states to be eligible for federal grants. Moreover, current federal revenues could close about 90 percent of the gaps 
between revenue capacity and expenditure need if closing these representative gaps were the main goal of federal intergovernmental aid. 


\section{Notes}

${ }^{1}$ General revenue includes both own-source revenue (e.g., taxes) and intergovernmental revenue from the federal government. It does not include liquor store, utility, or insurance trust revenue.

${ }^{2}$ The District of Columbia has been excluded from this study. D.C.'s characteristics resemble those of a municipality rather than a state; therefore, its results would not be comparable to those of other states. All "national" averages in this study are averages of the 50 states and exclude D.C. as well as other U.S. nonstate entities.

${ }^{3}$ Alaska's high expenditures may reflect higher-than-average costs of providing, need for, or demand for public services; a significant amount of expenditures, however, is cash rebates to Alaskan residents. In FY 2002 , over $\$ 1$ billion (an average of $\$ 1695$ a resident) was rebated through the Alaska Permanent Fund Dividend program (funded through oil windfalls). See http://www.pfd.state.ak.us/index.aspx for more information.

${ }^{4}$ For a history of Canada's equalization programs, including a discussion of capacity measures used in equalization formulas see appendix 2 of Achieving a National Purpose: Putting Equalization Back on Track, the May 2006 report of an Expert Panel on Equalization and Territorial Financing.

${ }^{5}$ The definition given in the 1962 ACIR report excludes the "relative to cost of service provision" part of the definition. The report defined fiscal capacity as "a quantitative measure intended to reflect the resources which a taxing jurisdiction can tax to raise revenue for public purposes."

${ }^{6}$ Box 4 expands on other metrics used to measure relative fiscal capacity across states or other regional governments.

${ }^{7}$ In comparison to the previous Tannenwald reports, "fiscal capacity" in this report refers to Tannenwald's "fiscal comfort," "tax/revenue capacity" to Tannenwald's "fiscal capacity," and "expenditure need" to Tannenwald's "fiscal need." "Tax/revenue effort" remains the same, and "expenditure effort" is a new term. ${ }^{8}$ See http://www.taxpolicycenter.org and http://www.bos.frb.org/economic/neppc.

${ }^{9}$ General charges include charges and fees on air transportation, commerce, education, hospitals, highways

accounted in these categories.

${ }^{10}$ Other taxes include other selective sales, amusement licenses, alcohol licenses, public utility licenses, occupational business licenses, other licenses, documentary and stock transfer fees, and taxes and fees not classified elsewhere. Other nontax revenues include revenues from property sales (housing/community development, and other), interest revenue, fines and forfeits, rents and royalties, private donations and other miscellaneous general revenue not recorded elsewhere.

${ }^{11}$ For example, the personal income tax base includes the federal adjustment amounts and residency adjustments because these adjustments exist as plausible sources of revenue for many states. Conversely, the calculations exclude from the tax base personal exemptions and exemptions for dependents because states are highly unlikely to remove dependent exemptions in the short run.

${ }^{12}$ Overall states' rankings on the index of revenue capacity also correlate strongly with per capita revenue capacity for the three major state and local taxes. Per capita revenue capacity for general sales and gross receipts can explain 68 percent of the variations in state rankings, personal income tax capacity can explain 84 percent of the variation, and the property tax capacity can explain 81 percent.

${ }^{13}$ Sometimes, census categories do not correspond with categories identified by state and local governments. For example, some states include hospital spending in welfare benefits while the census defines hospital spending as a health case expenditure. In this study, we use the definitions outlined in the Government Finance and Employment Classification Manual as our basis. See http://www.census.gov/govs/www/class.html.

${ }^{14}$ The top five jurisdictions with the highest per capita expenditure need (Arkansas, Mississippi, Louisiana, New Mexico, and Alabama) all have education and welfare accounting for 55 percent or more of their total expenditure needs. The national average for these three items is 49 percent of total expenditure need.

${ }^{15}$ It is possible that some non-policy factors not accounted for by the RES model-for example, weatherrelated transportation costs-or differences in public preferences over service quality or levels could account for the divergence between the actual expenditures and the expenditure needs. Additionally, it is important 
to note that having high relative expenditure effort need not imply wasteful spending (nor should under-spending be interpreted as under-provision of services).

${ }^{16}$ Tannenwald first developed this measure of fiscal comfort-tax capacity to expenditure need-in 1997. When Rafuse (1990b) introduced the representative expenditure approach, he used the term indices of fiscal capacity to refer to tax/revenue capacity and expenditure need and looked at the difference between these measures to calculate a hypothetical fiscal gap.

${ }^{17}$ Geographical categories are based on census divisions. Connecticut, Maine, Massachusetts, New Hampshire, Rhode Island, and Vermont make up New England; New Jersey, New York, and Pennsylvania make up the Middle Atlantic States; and both these divisions are in the Northeast region. Indiana, Illinois, Michigan, Ohio, and Wisconsin are the states in the East North Central Division. The West North Central Division includes Iowa, Kansas, Minnesota, Missouri, Nebraska, North Dakota, and South Dakota. These two divisions make up the Midwest region. The South includes the South Atlantic (Delaware, Florida, Georgia, Maryland, North Carolina, South Carolina, Virginia, and West Virginia), East South Central (Alabama, Kentucky, Mississippi, and Tennessee) and West South Central (Arkansas, Louisiana, Oklahoma, and Texas). Finally, the West is made up of the Mountain Division (Arizona, Colorado, Idaho, Montana, New Mexico, Nevada, Utah, and Wyoming) and the Pacific (Alaska, California, Hawaii, Oregon, and Washington).

${ }^{18}$ Between 1998 and 2003, Texas's crude oil production dropped by more than 120,000 barrels a year-to less than 35,000 barrels a month (Energy Information Association, "The Petroleum Navigator,"

http://tonto.eia.doe.gov/dnav/pet/hist/mcrfptx1m.htm).

${ }^{19}$ See UNESCO Institute of Statistics, Education Database, Table 19, "Finance Indicators by ISCED Level," http://stats.uis.unesco.org/TableViewer/tableView.aspx? ReportId=219.

${ }^{20}$ The authors thank Nick Johnson at the Center for Budget and Policy Priorities for this recommendation.

${ }^{21}$ The correlation between the actual expenditure and expenditure need is -0.14 , while the correlation coefficient for the expenditure need and effort indices is 0.38 .

${ }^{22}$ This discussion does not include the District of Columbia as a state. General revenues and expenditures exclude utility, liquor store, and insurance trust revenues and expenditures. Total revenues for all state and local governments in the United States were $\$ 1.8$ trillion, while total expenditures amounted to $\$ 2.05$ trillion. 


\section{References}

Expert Panel on Equalization and Territorial Formula Financing. 2006. "Achieving a National Purpose: Putting Equalization Back on Track." Ottawa, Ontario: Expert Panel on Equalization and Territorial Formula Financing.

Rafuse, Robert. 1990a. "Representative Expenditures: Addressing the Neglected Dimension of Fiscal Capacity." Washington, DC: U.S. Advisory Commission on Intergovernmental Relations. Report No. M-174, December. http://www.library.unt.edu/gpo/acir/Reports/information/m-174.pdf.

—. 1990b. "A Walk on the Expenditure Side: 'Needs' and Fiscal Capacity." Intergovernmental Perspective, Fall: 25-30.

Rothstein, Richard. 2001. "Closing the Gap: How the government Can Equalize Education Spending between the States." In School Spending, an Online Anthology from the American School Board Journal. http://www.asbj.com/schoolspending/resources0501rothstein.html.

Tannenwald, Robert. 1998. "Come the Devolution, Will States Be Able to Respond?" New England Economic Review May/June: 53-73.

—. 1999. "Fiscal Disparity Among the States Revisited." New England Economic Review July/August: 3-25.

—. 2002. "Interstate Fiscal Disparity in 1997." New England Economic Review Third Quarter: 17-33.

Tannenwald, Robert, and Nicholas Turner. 2004. "Interstate Fiscal Disparity in State Fiscal Year 1999." Public Policy Discussion Papers No 049. Boston, MA: Federal Reserve Bank of Boston. http://www.bos.frb.org/economic/ppdp/2004/ppdp0409.pdf.

U.S. Advisory Commission on Intergovernmental Relations. 1962. Measures of State and Local Fiscal Capacity and Tax Effort Report No. M-16, October. Washington, DC: ACIR. http://www.library.unt.edu/gpo/acir/Reports/information/M-16.pdf.

1993. RTS 1991: State Tax Capacity and Effort Report No. M-187, September. Washington, DC: ACIR.

http://www.library.unt.edu/gpo/ACIR/Reports/information/m-187.pdf. 


\section{Tables and figures}

Note: Unless otherwise specified, United States totals for all tables, figures, and appendix tables do not include the District of Columbia.

Table 1. Representative revenue system, 2002

\begin{tabular}{|c|c|c|c|c|}
\hline \multirow[b]{2}{*}{ Revenue source } & \multicolumn{2}{|c|}{ State and local revenues } & \multicolumn{2}{|c|}{ Bases and rates } \\
\hline & $\begin{array}{l}\text { Amount } \\
\text { (\$ billions) }\end{array}$ & Percent of total & $\begin{array}{l}\text { Standard base } \\
\text { (billions) }\end{array}$ & Representative rate \\
\hline $\begin{array}{l}\text { General sales and gross } \\
\text { receipts }\end{array}$ & 222.43 & 16.61 & $3,412.63$ & 6.52 cents per dollar \\
\hline Selective sales & 89.77 & 6.70 & & \\
\hline Motor fuel & 33.01 & 2.47 & 166.62 & 19.81 cents per gallon \\
\hline Public utilities & 20.10 & 1.50 & 603.38 & 3.33 cents per dollar \\
\hline Insurance & 11.16 & 0.83 & 926.76 & 1.2 cents per dollar \\
\hline Tobacco & 9.08 & 0.68 & 20.41 & 44.5 cents per package \\
\hline Alcoholic beverages & 12.04 & 0.90 & & \\
\hline Distilled spirits & 4.80 & 0.36 & 0.14 & $\$ 33.47$ per gallon \\
\hline Beer & 5.87 & 0.44 & 0.29 & $\$ 20.15$ per gallon \\
\hline Wine & 1.37 & 0.10 & 0.06 & $\$ 22.27$ per gallon \\
\hline Amusements & 4.08 & 0.30 & 125.62 & 3.25 cents per dollar \\
\hline Pari-mutuels & 0.31 & 0.02 & 18.11 & 1.7 cents per dollar \\
\hline License taxes & 25.36 & 1.89 & & \\
\hline Motor vehicles & 16.92 & 1.26 & 229.84 & $\$ 73.64$ per license \\
\hline Vehicle operators & 1.42 & 0.11 & 194.53 & $\$ 7.29$ per license \\
\hline Corporate licenses & 5.84 & 0.44 & 5.65 & $\$ 1,035$ per license \\
\hline $\begin{array}{l}\text { Fishing and hunting } \\
\text { licenses }\end{array}$ & 1.18 & 0.09 & 43.30 & $\$ 27.30$ per license \\
\hline Personal income tax & 201.91 & 15.08 & $6,013.23$ & 3.36 cents per dollar \\
\hline Corporate income tax & 27.94 & 2.09 & 573.87 & 4.87 cents per dollar \\
\hline Property tax & 278.32 & 20.79 & $20,951.29$ & 1.33 cents per dollar \\
\hline Death and gift tax & 7.38 & 0.55 & 26.40 & 27.97 cents per dollar \\
\hline Severance taxes & 4.23 & 0.32 & 131.29 & 3.22 cents per dollar \\
\hline Other taxes & 51.84 & 3.87 & $8,847.08$ & 0.59 cents per dollar \\
\hline $\begin{array}{l}\text { User charges and nontax } \\
\text { revenues }\end{array}$ & 429.75 & 32.10 & & \\
\hline Lotteries & 15.77 & 1.18 & 39.26 & 40.15 cents per dollar \\
\hline General user charges & 264.22 & 19.73 & $8,847.08$ & 2.99 cents per dollar \\
\hline Other nontax revenues & 149.76 & 11.18 & $8,847.08$ & 1.69 cents per dollar \\
\hline RRS total & $1,338.95$ & $100 \%$ & & \\
\hline
\end{tabular}

${ }^{a}$ The tax base value is expressed in the applicable units. For ad valorem taxes, this value is dollars; for excise taxes issued per unit sold the base is measured in kind. 
Table 2. Revenue capacity and effort, index and rankings, 2002

\begin{tabular}{|c|c|c|c|c|c|c|}
\hline State & Revenue capacity $(\$)$ & $\begin{array}{c}\text { Revenue } \\
\text { capacity index }\end{array}$ & Rank & $\begin{array}{c}\text { Revenue } \\
\text { collection }(\$)\end{array}$ & Revenue effort index & Rank \\
\hline United States & 4,659 & 100 & . & 4,659 & 100 & . \\
\hline Connecticut & 6,272 & 135 & 1 & 5,446 & 87 & 46 \\
\hline Massachusetts & 5,994 & 129 & 2 & 5,179 & 86 & 47 \\
\hline Delaware & 5,678 & 122 & 3 & 5,982 & 105 & 12 \\
\hline New Jersey & 5,651 & 121 & 4 & 5,554 & 98 & 29 \\
\hline Alaska & 5,496 & 118 & 5 & 8,537 & 155 & 1 \\
\hline New Hampshire & 5,482 & 118 & 5 & 4,142 & 76 & 50 \\
\hline Wyoming & 5,370 & 115 & 7 & 6,160 & 115 & 3 \\
\hline Colorado & 5,282 & 113 & 8 & 4,891 & 93 & 40 \\
\hline New York & 5,240 & 112 & 9 & 6,376 & 122 & 2 \\
\hline Nevada & 5,217 & 112 & 9 & 4,619 & 89 & 43 \\
\hline California & 5,059 & 109 & 11 & 5,174 & 102 & 20 \\
\hline Minnesota & 5,057 & 109 & 11 & 5,446 & 108 & 8 \\
\hline Maryland & 5,007 & 107 & 13 & 4,908 & 98 & 29 \\
\hline Washington & 4,871 & 105 & 14 & 4,919 & 101 & 22 \\
\hline Hawaii & 4,848 & 104 & 15 & 4,802 & 99 & 27 \\
\hline Illinois & 4,843 & 104 & 15 & 4,540 & 94 & 37 \\
\hline Virginia & 4,750 & 102 & 17 & 4,556 & 96 & 33 \\
\hline Florida & 4,730 & 102 & 17 & 4,398 & 93 & 40 \\
\hline Rhode Island & 4,701 & 101 & 19 & 4,627 & 98 & 29 \\
\hline Vermont & 4,662 & 100 & 20 & 4,528 & 97 & 32 \\
\hline Oregon & 4,629 & 99 & 21 & 4,401 & 95 & 35 \\
\hline Michigan & 4,527 & 97 & 22 & 4,570 & 101 & 22 \\
\hline Wisconsin & 4,482 & 96 & 23 & 4,837 & 108 & 8 \\
\hline Nebraska & 4,430 & 95 & 24 & 4,586 & 104 & 14 \\
\hline Pennsylvania & 4,418 & 95 & 24 & 4,606 & 104 & 14 \\
\hline North Dakota & 4,402 & 94 & 26 & 4,541 & 103 & 18 \\
\hline Ohio & 4,380 & 94 & 26 & 4,584 & 105 & 12 \\
\hline Iowa & 4,368 & 94 & 26 & 4,556 & 104 & 14 \\
\hline South Dakota & 4,349 & 93 & 29 & 3,689 & 85 & 48 \\
\hline Georgia & 4,346 & 93 & 29 & 4,126 & 95 & 35 \\
\hline Missouri & 4,346 & 93 & 29 & 3,849 & 89 & 43 \\
\hline Maine & 4,342 & 93 & 29 & 4,844 & 112 & 6 \\
\hline Indiana & 4,308 & 92 & 33 & 4,272 & 99 & 27 \\
\hline North Carolina & 4,282 & 92 & 33 & 4,111 & 96 & 33 \\
\hline Texas & 4,271 & 92 & 33 & 4,017 & 94 & 37 \\
\hline Kansas & 4,224 & 91 & 36 & 4,289 & 102 & 20 \\
\hline Kentucky & 4,219 & 91 & 36 & 3,898 & 92 & 42 \\
\hline Montana & 4,208 & 90 & 38 & 3,954 & 94 & 37 \\
\hline Arizona & 4,147 & 89 & 39 & 3,682 & 89 & 43 \\
\hline Tennessee & 4,139 & 89 & 39 & 3,451 & 83 & 49 \\
\hline Utah & 3,985 & 86 & 41 & 4,318 & 108 & 8 \\
\hline New Mexico & 3,946 & 85 & 42 & 4,212 & 107 & 11 \\
\hline Idaho & 3,915 & 84 & 43 & 3,959 & 101 & 22 \\
\hline South Carolina & 3,861 & 83 & 44 & 3,908 & 101 & 22 \\
\hline Louisiana & 3,846 & 83 & 44 & 4,398 & 114 & 4 \\
\hline Oklahoma & 3,835 & 82 & 46 & 3,977 & 104 & 14 \\
\hline Alabama & 3,820 & 82 & 46 & 3,931 & 103 & 18 \\
\hline Arkansas & 3,557 & 76 & 48 & 3,580 & 101 & 22 \\
\hline West Virginia & 3,552 & 76 & 48 & 4,015 & 113 & 5 \\
\hline Mississippi & 3,352 & 72 & 50 & 3,768 & 112 & 6 \\
\hline
\end{tabular}


Table 3. Expenditure need and effort, index and rankings

\begin{tabular}{|c|c|c|c|c|c|c|}
\hline State & $\begin{array}{c}\text { Expenditure } \\
\text { need }(\$)\end{array}$ & $\begin{array}{c}\text { Expenditure } \\
\text { need index }\end{array}$ & Rank & $\begin{array}{c}\text { Actual } \\
\text { expenditures }(\$)\end{array}$ & $\begin{array}{l}\text { Expenditure } \\
\text { effort index }\end{array}$ & Rank \\
\hline United States & 6,007 & 100 & . & 6,007 & 100 & . \\
\hline Mississippi & 6,800 & 113 & 1 & 5,365 & 79 & 47 \\
\hline Louisiana & 6,631 & 110 & 2 & 5,359 & 81 & 45 \\
\hline Arkansas & 6,539 & 109 & 3 & 4,827 & 74 & 50 \\
\hline Alabama & 6,492 & 108 & 4 & 5,491 & 85 & 44 \\
\hline New Mexico & 6,460 & 108 & 4 & 6,164 & 95 & 28 \\
\hline Texas & 6,456 & 107 & 6 & 5,127 & 79 & 47 \\
\hline Georgia & 6,297 & 105 & 7 & 5,416 & 86 & 40 \\
\hline South Carolina & 6,291 & 105 & 7 & 5,801 & 92 & 32 \\
\hline Tennessee & 6,271 & 104 & 9 & 4,998 & 80 & 46 \\
\hline Michigan & 6,255 & 104 & 9 & 6,075 & 97 & 25 \\
\hline North Dakota & 6,248 & 104 & 9 & 6,132 & 98 & 24 \\
\hline West Virginia & 6,227 & 104 & 9 & 5,469 & 88 & 37 \\
\hline California & 6,211 & 103 & 13 & 6,732 & 108 & 16 \\
\hline Utah & 6,181 & 103 & 13 & 5,544 & 90 & 34 \\
\hline Kentucky & 6,141 & 102 & 15 & 5,268 & 86 & 40 \\
\hline Arizona & 6,128 & 102 & 15 & 4,745 & 77 & 49 \\
\hline Illinois & 6,126 & 102 & 15 & 5,866 & 96 & 26 \\
\hline North Carolina & 6,113 & 102 & 15 & 5,359 & 88 & 37 \\
\hline Oklahoma & 6,059 & 101 & 19 & 5,205 & 86 & 40 \\
\hline New York & 6,052 & 101 & 19 & 8,414 & 139 & 2 \\
\hline Alaska & 5,995 & 100 & 21 & 13,175 & 220 & 1 \\
\hline Indiana & 5,908 & 98 & 22 & 5,320 & 90 & 34 \\
\hline Wyoming & 5,894 & 98 & 22 & 7,719 & 131 & 3 \\
\hline Idaho & 5,880 & 98 & 22 & 5,065 & 86 & 40 \\
\hline Kansas & 5,846 & 97 & 25 & 5,482 & 94 & 29 \\
\hline Missouri & 5,816 & 97 & 25 & 5,114 & 88 & 37 \\
\hline Ohio & 5,814 & 97 & 25 & 5,876 & 101 & 21 \\
\hline Montana & 5,798 & 97 & 25 & 5,546 & 96 & 26 \\
\hline New Jersey & 5,797 & 97 & 25 & 6,341 & 109 & 15 \\
\hline Washington & 5,791 & 96 & 30 & 6,370 & 110 & 13 \\
\hline Connecticut & 5,772 & 96 & 30 & 6,996 & 121 & 6 \\
\hline Virginia & 5,764 & 96 & 30 & 5,399 & 94 & 29 \\
\hline South Dakota & 5,745 & 96 & 30 & 5,108 & 89 & 36 \\
\hline Massachusetts & 5,709 & 95 & 34 & 6,600 & 116 & 8 \\
\hline Maryland & 5,688 & 95 & 34 & 5,871 & 103 & 20 \\
\hline Florida & 5,666 & 94 & 36 & 5,219 & 92 & 32 \\
\hline Nebraska & 5,619 & 94 & 36 & 5,645 & 100 & 22 \\
\hline Colorado & 5,610 & 93 & 38 & 6,054 & 108 & 16 \\
\hline Pennsylvania & 5,609 & 93 & 38 & 5,947 & 106 & 19 \\
\hline Oregon & 5,605 & 93 & 38 & 6,525 & 116 & 8 \\
\hline Rhode Island & 5,603 & 93 & 38 & 6,321 & 113 & 10 \\
\hline Maine & 5,593 & 93 & 38 & 6,124 & 110 & 13 \\
\hline Wisconsin & 5,566 & 93 & 38 & 6,250 & 112 & 11 \\
\hline Delaware & 5,557 & 93 & 38 & 6,643 & 120 & 7 \\
\hline Minnesota & 5,553 & 92 & 45 & 6,952 & 125 & 5 \\
\hline Vermont & 5,493 & 91 & 46 & 6,172 & 112 & 11 \\
\hline Iowa & 5,491 & 91 & 46 & 5,856 & 107 & 18 \\
\hline Nevada & 5,489 & 91 & 46 & 5,427 & 99 & 23 \\
\hline New Hampshire & 5,282 & 88 & 49 & 4,973 & 94 & 29 \\
\hline Hawaii & 5,216 & 87 & 50 & 6,715 & 129 & 4 \\
\hline
\end{tabular}


Table 4. Fiscal capacity index and rankings, FY 2002

\begin{tabular}{|c|c|c|}
\hline State & Fiscal capacity index & Rank \\
\hline United States & 100 & \\
\hline Connecticut & 141 & 1 \\
\hline Massachusetts & 136 & 2 \\
\hline New Hampshire & 134 & 3 \\
\hline Delaware & 131 & 4 \\
\hline New Jersey & 125 & 5 \\
\hline Nevada & 123 & 6 \\
\hline Colorado & 122 & 7 \\
\hline Hawaii & 120 & 8 \\
\hline Alaska & 118 & 9 \\
\hline Minnesota & 118 & 9 \\
\hline Wyoming & 117 & 11 \\
\hline Maryland & 113 & 12 \\
\hline New York & 111 & 13 \\
\hline Vermont & 110 & 14 \\
\hline Florida & 109 & 15 \\
\hline Rhode Island & 109 & 15 \\
\hline Washington & 109 & 15 \\
\hline California & 106 & 18 \\
\hline Oregon & 106 & 18 \\
\hline Virginia & 106 & 18 \\
\hline Iowa & 103 & 21 \\
\hline Wisconsin & 103 & 21 \\
\hline Illinois & 102 & 23 \\
\hline Pennsylvania & 102 & 23 \\
\hline Nebraska & 101 & 25 \\
\hline Maine & 100 & 26 \\
\hline Ohio & 97 & 27 \\
\hline South Dakota & 97 & 27 \\
\hline Missouri & 96 & 29 \\
\hline Indiana & 94 & 30 \\
\hline Kansas & 94 & 30 \\
\hline Michigan & 93 & 32 \\
\hline Montana & 93 & 32 \\
\hline North Carolina & 90 & 34 \\
\hline North Dakota & 90 & 34 \\
\hline Georgia & 89 & 36 \\
\hline Kentucky & 89 & 36 \\
\hline Arizona & 87 & 38 \\
\hline Idaho & 86 & 39 \\
\hline Tennessee & 86 & 39 \\
\hline Texas & 86 & 39 \\
\hline Utah & 83 & 42 \\
\hline Oklahoma & 81 & 43 \\
\hline New Mexico & 79 & 44 \\
\hline South Carolina & 79 & 44 \\
\hline Alabama & 76 & 46 \\
\hline Louisiana & 75 & 47 \\
\hline West Virginia & 73 & 48 \\
\hline Arkansas & 70 & 49 \\
\hline Mississippi & 64 & 50 \\
\hline
\end{tabular}


Table 5. Per capita fiscal gap at capacity, actual fiscal gap, federal transfers, and debt issue, FY 2002 (dollars)

\begin{tabular}{|c|c|c|c|c|c|}
\hline State & $\begin{array}{c}\text { Fiscal gap at } \\
\text { capacity }\end{array}$ & $\begin{array}{c}\text { Actual } \\
\text { fiscal gap }\end{array}$ & $\begin{array}{c}\text { Federal government } \\
\text { transfers }\end{array}$ & $\begin{array}{c}\text { Actual gap, after } \\
\text { transfers }\end{array}$ & $\begin{array}{c}\text { Gap at capacity, } \\
\text { after transfers }\end{array}$ \\
\hline United States & 1,348 & 1,348 & 1,245 & 103 & 103 \\
\hline Connecticut & $(500)$ & 1,550 & 1,168 & 382 & $(1,668)$ \\
\hline Massachusetts & $(285)$ & 1,422 & 963 & 459 & $(1,248)$ \\
\hline New Hampshire & $(200)$ & 831 & 1,016 & $(185)$ & $(1,216)$ \\
\hline Delaware & $(121)$ & 661 & 1,191 & $(530)$ & $(1,312)$ \\
\hline New Jersey & 147 & 787 & 1,043 & $(257)$ & $(897)$ \\
\hline Nevada & 272 & 807 & 753 & 55 & $(481)$ \\
\hline Colorado & 328 & 1,163 & 949 & 214 & $(621)$ \\
\hline Hawaii & 369 & 1,912 & 1,254 & 659 & $(885)$ \\
\hline Minnesota & 496 & 1,505 & 1,212 & 294 & $(715)$ \\
\hline Alaska & 499 & 4,638 & 2,792 & 1,846 & $(2,293)$ \\
\hline Wyoming & 524 & 1,560 & 2,378 & $(819)$ & $(1,854)$ \\
\hline Maryland & 681 & 962 & 1,089 & $(127)$ & $(408)$ \\
\hline New York & 812 & 2,038 & 1,889 & 148 & $(1,077)$ \\
\hline Vermont & 831 & 1,644 & 1,763 & $(120)$ & $(932)$ \\
\hline Rhode Island & 902 & 1,694 & 1,652 & 42 & $(750)$ \\
\hline Washington & 920 & 1,450 & 1,161 & 290 & $(241)$ \\
\hline Florida & 936 & 821 & 897 & (75) & 40 \\
\hline Oregon & 975 & 2,124 & 1,827 & 297 & $(852)$ \\
\hline Virginia & 1,014 & 843 & 857 & (15) & 156 \\
\hline Wisconsin & 1,084 & 1,413 & 1,187 & 226 & $(102)$ \\
\hline Iowa & 1,123 & 1,300 & 1,236 & 64 & $(112)$ \\
\hline California & 1,152 & 1,558 & 1,379 & 179 & $(227)$ \\
\hline Nebraska & 1,189 & 1,059 & 1,143 & (84) & 46 \\
\hline Pennsylvania & 1,191 & 1,341 & 1,300 & 41 & (109) \\
\hline Maine & 1,251 & 1,280 & 1,465 & (184) & $(213)$ \\
\hline Illinois & 1,283 & 1,326 & 1,010 & 316 & 272 \\
\hline South Dakota & 1,396 & 1,420 & 1,513 & (93) & $(117)$ \\
\hline Ohio & 1,434 & 1,292 & 1,215 & 77 & 219 \\
\hline Missouri & 1,470 & 1,265 & 1,290 & $(25)$ & 179 \\
\hline Montana & 1,590 & 1,593 & 1,746 & $(154)$ & $(156)$ \\
\hline Indiana & 1,600 & 1,048 & 1,020 & 28 & 580 \\
\hline Kansas & 1,622 & 1,193 & 1,142 & 51 & 480 \\
\hline Michigan & 1,728 & 1,505 & 1,250 & 255 & 478 \\
\hline North Carolina & 1,831 & 1,247 & 1,232 & 15 & 599 \\
\hline North Dakota & 1,846 & 1,591 & 1,824 & (233) & 22 \\
\hline Kentucky & 1,922 & 1,370 & 1,324 & 47 & 599 \\
\hline Georgia & 1,950 & 1,290 & 1,096 & 194 & 855 \\
\hline Idaho & 1,965 & 1,106 & 1,054 & 53 & 912 \\
\hline Arizona & 1,981 & 1,063 & 1,051 & 11 & 930 \\
\hline Tennessee & 2,132 & 1,548 & 1,313 & 235 & 819 \\
\hline Texas & 2,185 & 1,109 & 1,055 & 54 & 1,130 \\
\hline Utah & 2,195 & 1,226 & 1,126 & 100 & 1,069 \\
\hline Oklahoma & 2,224 & 1,228 & 1,265 & (37) & 959 \\
\hline South Carolina & 2,429 & 1,894 & 1,299 & 595 & 1,131 \\
\hline New Mexico & 2,514 & 1,952 & 1,684 & 269 & 830 \\
\hline Alabama & 2,672 & 1,560 & 1,398 & 163 & 1,275 \\
\hline West Virginia & 2,675 & 1,454 & 1,662 & (209) & 1,012 \\
\hline Louisiana & 2,786 & 961 & 1,448 & $(487)$ & 1,337 \\
\hline Arkansas & 2,982 & 1,246 & 1,346 & $(100)$ & 1,635 \\
\hline Mississippi & 3,448 & 1,597 & 1,613 & $(16)$ & 1,835 \\
\hline Unweighted average & 1,349 & 1,409 & 1,331 & 78 & 18 \\
\hline
\end{tabular}


Figure 1. Geographical distribution of revenue capacity index scores by quintiles, FY 2002

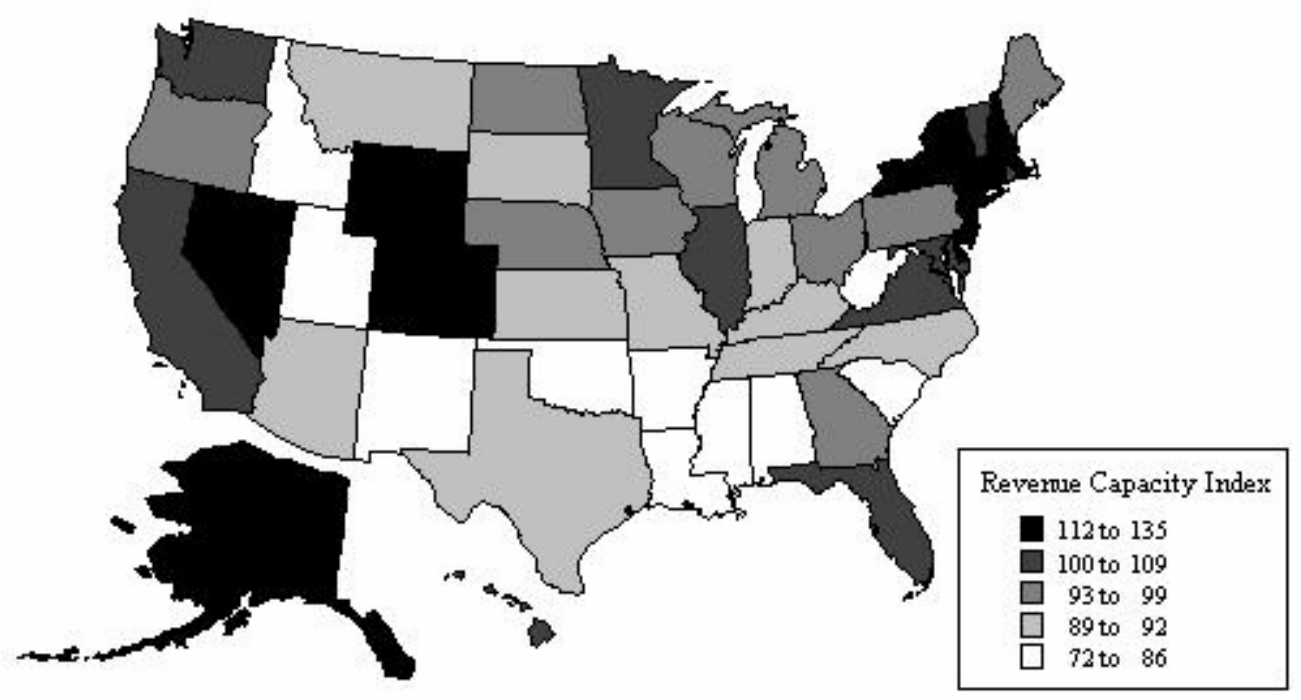

Figure 2. Geographical distribution of revenue effort index scores by quintiles, FY 2002

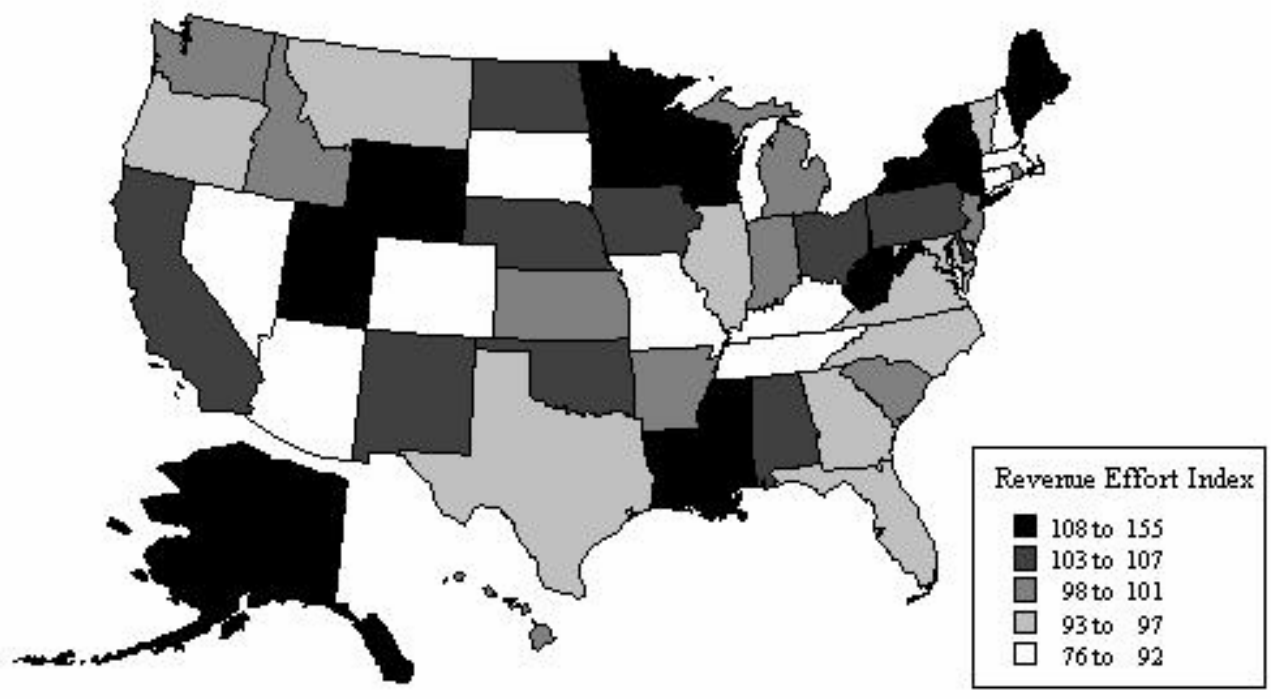


Figure 3. Geographical distribution of expenditure need index scores by quintiles, FY 2002

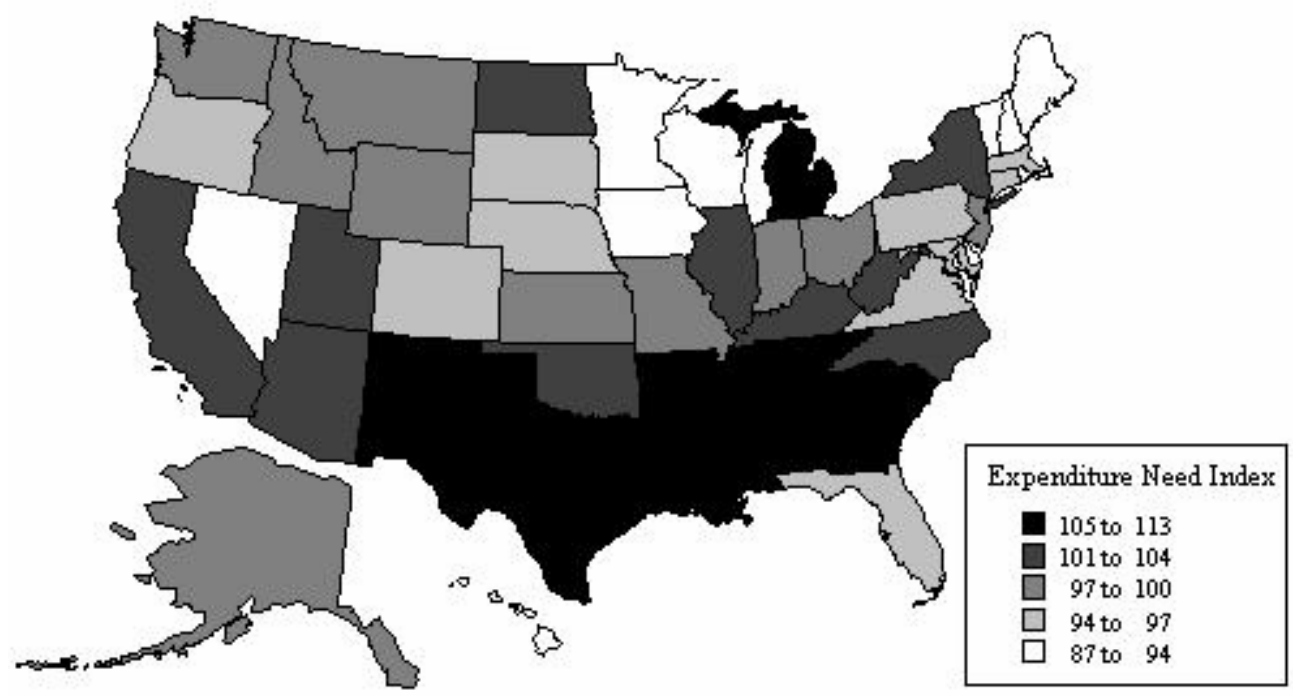

Figure 4. Geographical distribution of expenditure effort index scores by quintiles, FY 2002

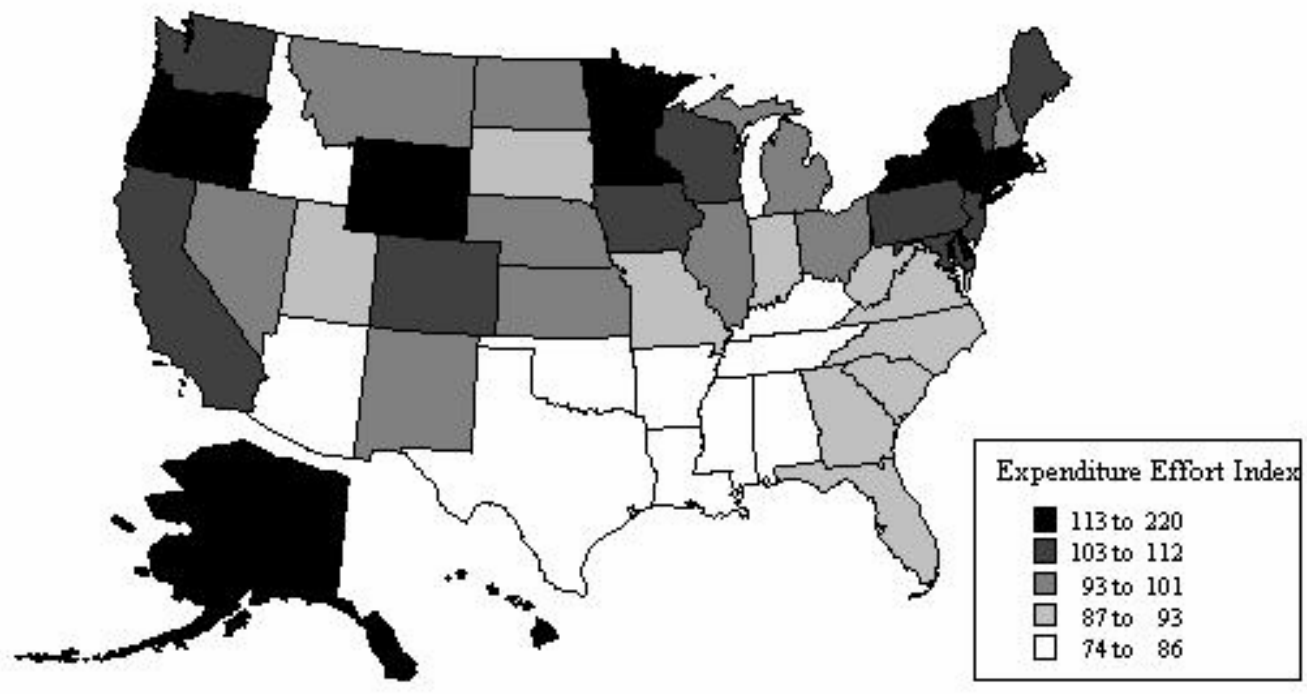


Figure 5. Relationship between expenditure effort and revenue capacity, FY 2002

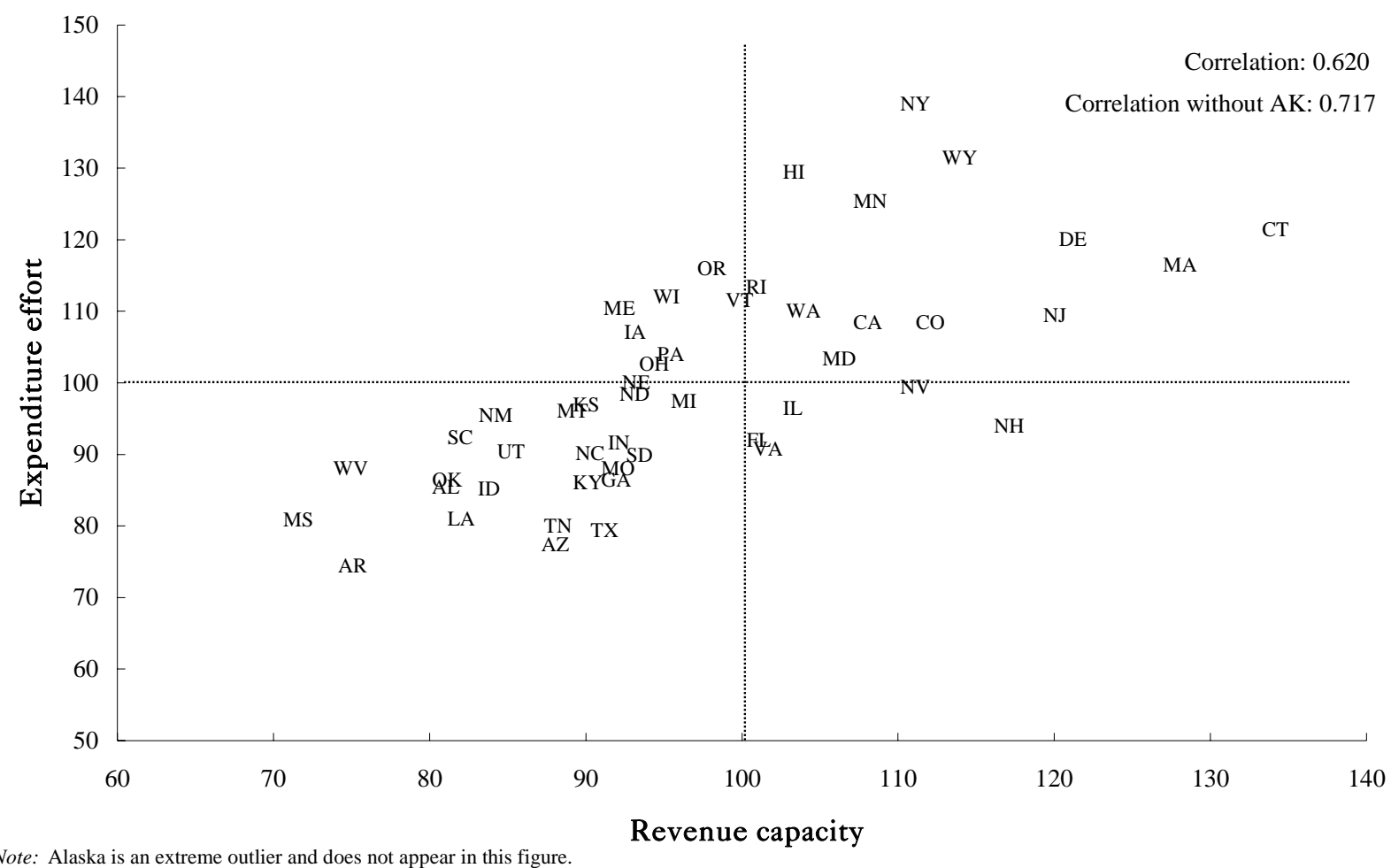

Figure 6. Geographical distribution of fiscal capacity index scores by quintiles, FY 2002

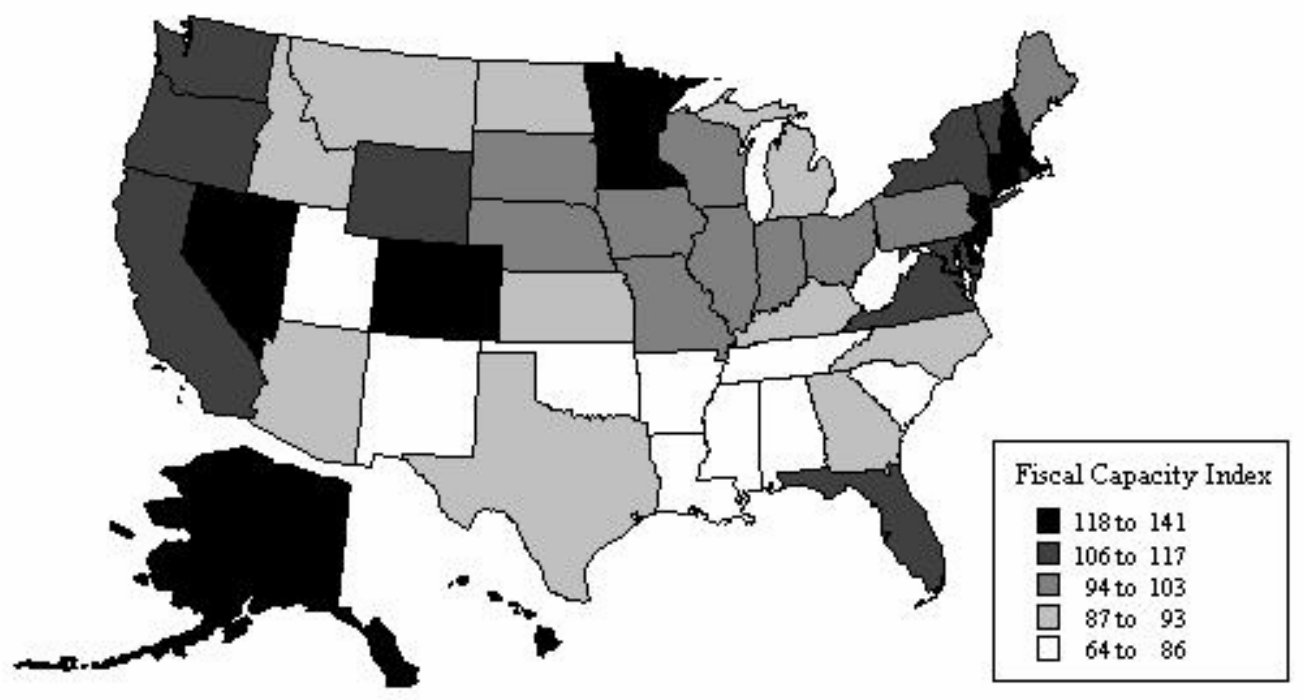


Figure 7. Relationship between expenditure need and revenue capacity, FY 2002

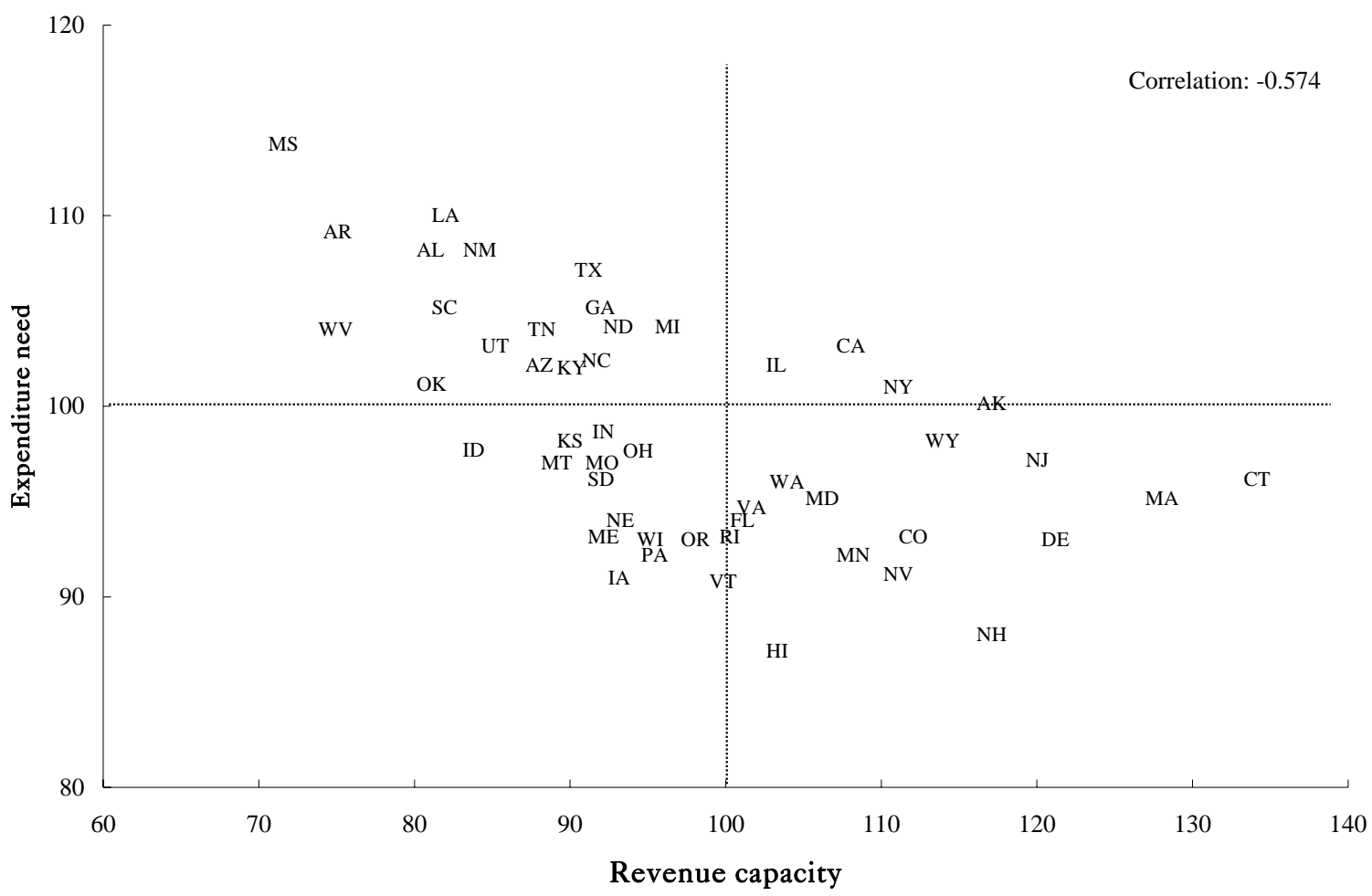

Figure 8. Relationship between revenue effort and fiscal capacity, FY 2002

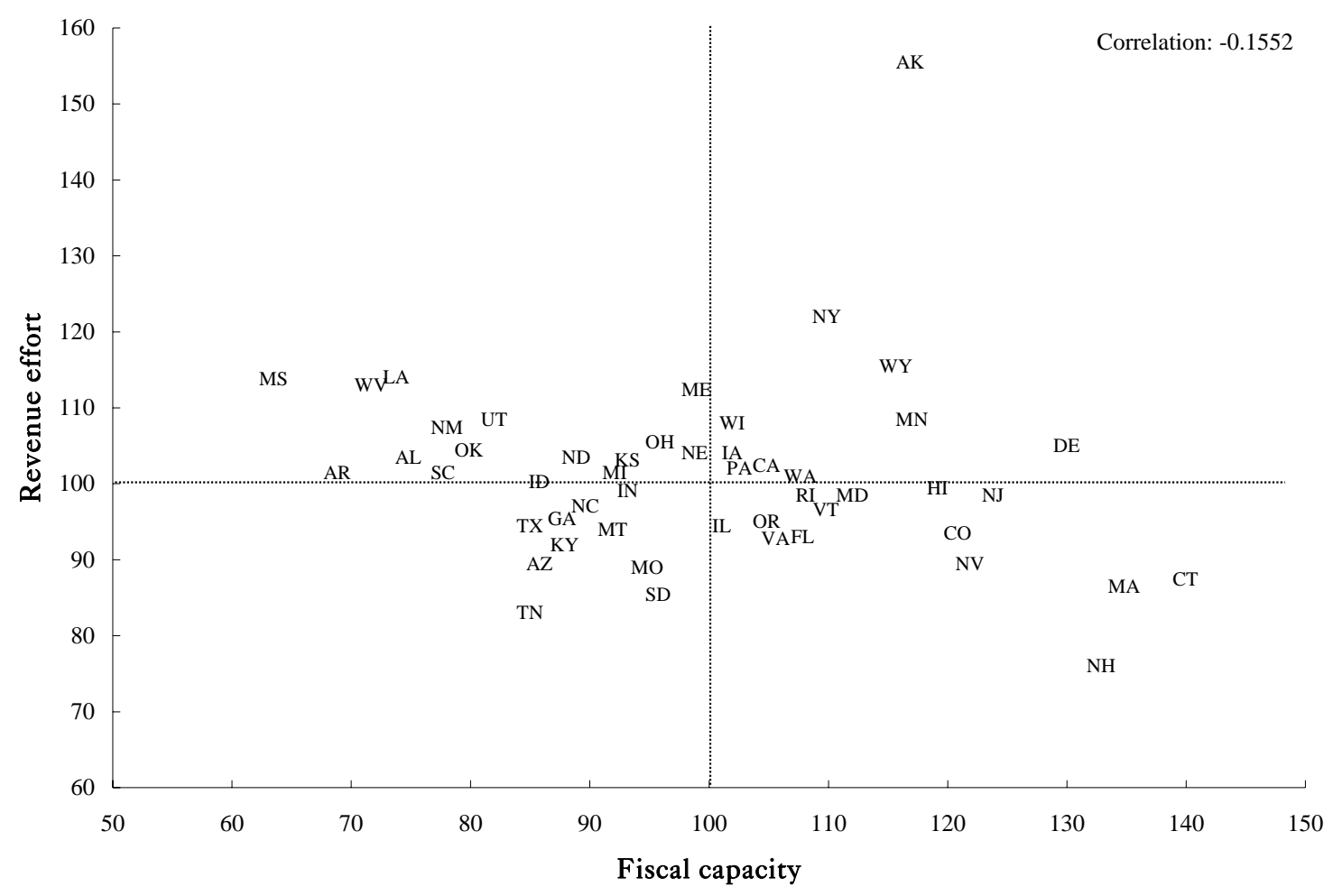


Figure 9. Relationship between federal transfers and fiscal gap at capacity, FY 2002

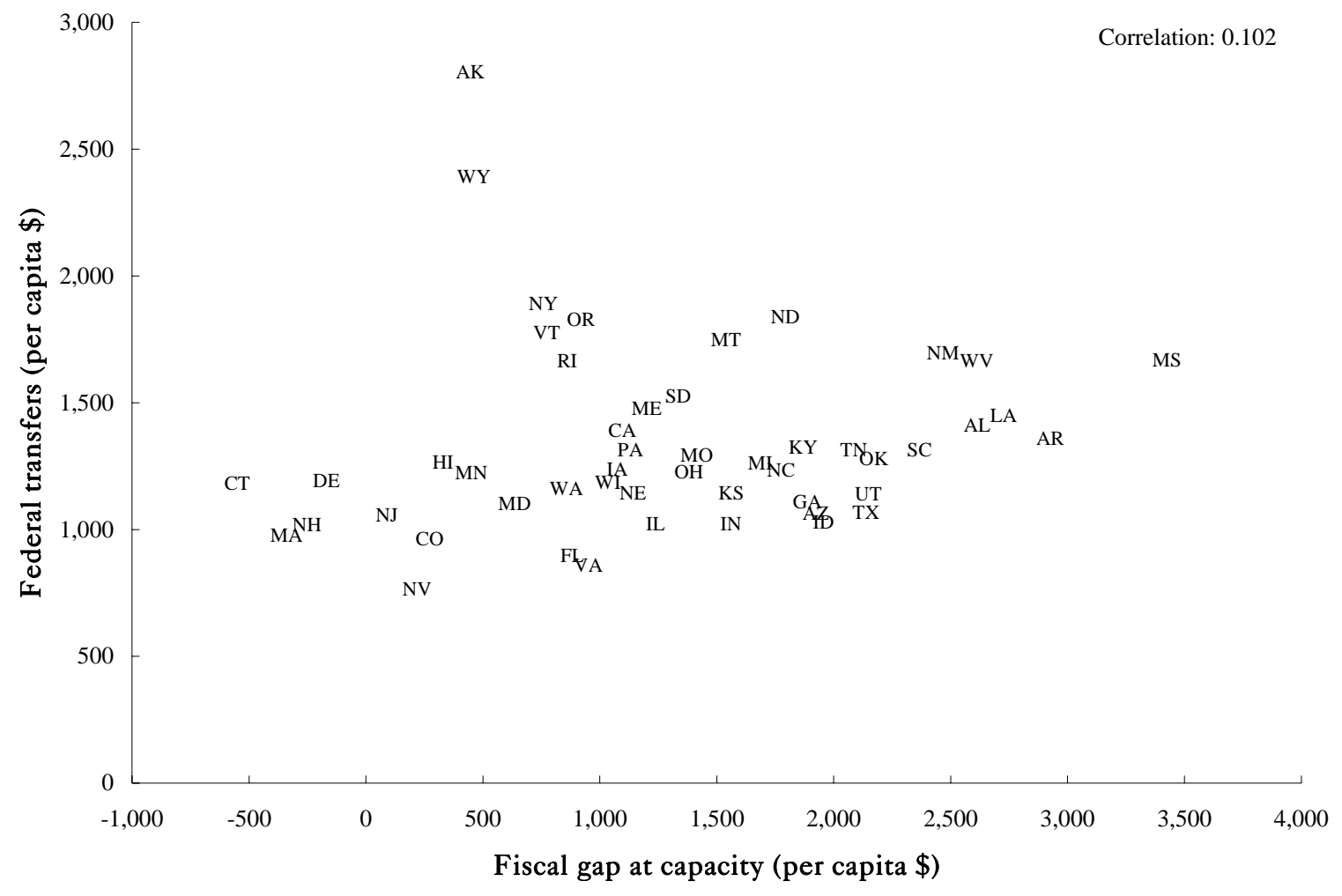




\begin{abstract}
About the authors
Yesim Yilmaz is an economist who works on public finance, taxation, education finance, decentralization, and governance. Dr. Yilmaz has worked with the World Bank education finance and governance and is an Earhart Fellow at the Center for Freedom and Prosperity, writing on tax competition and international taxation. She currently directs the Business Studies Program at SMARTHINKING.com.
\end{abstract}

Sonya $\mathrm{Hoo}$ is a research assistant at the Urban Institute. She researches the distributional and revenue effects of state and local tax systems and oversaw implementation of the Tax Policy Center State and Local Data Query System.

Matthew Nagowski is a research assistant at the New England Public Policy Center at the Federal Reserve Bank of Boston. Previously, Matthew was employed with the Cornell Higher Education Research Institute and at the Brookings Institution.

Kim Rueben is a senior research associate at the Urban Institute and the Tax Policy Center, a joint venture of the Urban Institute and the Brookings Institution. She currently heads the state policy effort of the Tax Policy Center. Dr. Rueben is an expert on state and local public finance, state and local government budget decisions, and the economics of education.

Robert Tannenwald is a vice president and economist at the Federal Reserve Bank of Boston and is director of its New England Public Policy Center. He has published extensively in the field of state and local public finance and has directed the work of three state tax study commissions. He is currently serving as first vice president of the National Tax Association and is on the board of directors of the New England Economic Partnership. 


\section{Appendix A: Glossary of terms}

Expenditure effort is the ratio of a state's actual per capita expenditures to the state's expenditure need.

Expenditure need measures how much a state must spend on a per capita basis to provide basic services typically offered by state and local governments. The expenditure need for each expenditure item is calculated using a workload factor, which measures the relative need of a state, based on characteristics not directly influenced by policies, such as socioeconomic and demographic characteristics. The expenditure need also reflects the variations in the costs of inputs across different jurisdictions. Ranking of states in terms of their per capita expenditure needs indexed to the national average per capita expenditures yields the index of expenditure need.

Fiscal capacity is a state's revenue capacity relative to its expenditure need. It is calculated as the ratio of revenue capacity to the expenditure need, both measured on a per capita basis. Multiplying this ratio by 100 and ranking states by their score gives us the index of fiscal capacity.

Fiscal gap is the difference between how much a state spends and how much it raises. The fiscal gap at capacity is the hypothetical difference between how much a state would spend and how much it would raise assuming representative revenue and expenditure policies.

Representative rate is the average tax/user charge rate that prevails in the nation; it is calculated by dividing the national total of states' revenues by the total revenue base for a given revenue item.

Representative revenue system (RRS) is the collection of the representative tax rates, user charges, and other revenues for each revenue item.

Representative tax system (RTS) is the collection of the representative tax rates for each tax item.

Revenue capacity adds user charges/fees and other nontax revenues (for example, lotteries, interest income, and proceeds from land sales) to the tax capacity analysis. It is the total amount of revenues a state and its localities would have raised if it were to apply a uniform set of taxes and user charges representative of the actual policies prevailing across the nation. The index of revenue capacity ranks states in terms of their per capita revenue capacities relative to the national average.

Revenue effort is the ratio of actual revenues collected by the state to the state's revenue capacity. Ranking each state's revenue effort relative to the national average creates the index of revenue effort. 
Standard revenue base is the nationwide value (or volume) of all economic stocks or flows that the state governments could tax; it is a comprehensive base devoid of exclusions, deductions, and other tax preferences and tax relief items.

Tax capacity is the total amount of tax revenues a state (and its localities) would have raised if it were to apply a uniform set of taxes "representative" of the actual policies prevailing across the nation. The index of tax capacity ranks states in terms of their per capita tax capacities relative to the national average. 


\section{Appendix B: Data sources and methodology for representative revenue system (RRS) - $\mathbf{2 0 0 2}$}

This section lays out the details of the representative revenue system (RRS), including data sources used and adjustments made to obtain the 2002 results. For the methodologies used in studies from prior years, please consult State Tax Capacity and Effort by the Advisory Commission on Intergovernmental Relations (1993) and the Interstate Fiscal Disparity studies by Tannenwald (1998, 1999, 2002) and Tannenwald and Turner (2004).

The RRS estimates a state's revenue capacity (or revenue raising potential) by levying a standard rate on a uniform revenue base for each revenue item (taxes, user charges and fees, and other nontax revenues) in every state. For every revenue item, the standard rate represents the national average tax or user charge rate, and it is calculated by dividing the national total of tax or user charge collections for that item by the total national revenue base. (When this exercise is done only for taxes, excluding user charges, fees, and other nontax sources of revenue, one obtains the representative tax system, or RTS.)

For example, in fiscal year 2002, total state and local revenues raised from personal income tax were roughly $\$ 202$ billion, while the standard base-defined as personal income modified for exemptions and federal and residency adjustments-was roughly $\$ 6$ trillion (see below for details). Therefore, the standard personal income tax rate-that is, the total tax receipts divided by the total base-for FY 2002 is 3.36 cents per dollar. Applying this rate to a given state's base-for example, Virginia's $\$ 128$ billion personal income tax baseand dividing by the state's population yields the per capita tax capacity (about $\$ 590$ for Virginia). The total per capita revenue capacity in each state is the sum of the per capita revenue capacity estimates for all taxes and user charges ( $\$ 4,750$ for Virginia). Calculating the relative position of each state compared with the national average revenue capacity-for 2002, the national average per capita revenue capacity was $\$ 4,660$ - and indexing to 100 creates an index of revenue capacity. Virginia scored 102 on this index, ranking number 17 among all states.

Comparing actual revenue collections to the potential revenue capacity, again indexed to the national average, creates the index of revenue effort. This measure reveals how intensively each state taxes-both within each tax or user charge category, and in total revenues relative to the national average. Following our example, Virginia collected $\$ 4,556$ per capita in tax and nontax revenues in FY 2002, and scored 96 on the index of tax effort, ranking 33rd among all other states.

The remainder of this appendix highlights the data sources used in calculating the standard bases and rates. Each category includes a brief description of the methodology used in constructing the tax base and notes any changes and adjustments made to calculate tax bases and rates. 


\section{State and local tax collections (including taxes and charges)}

Source

U.S. Bureau of the Census. Annual Survey of Government Finances, State and Local Finances by Type of Government.

http://ftp2.census.gov/govs/estimate/02statetypecd.zip.

\section{2 population data (based on mid-year population estimates)}

Source

U.S. Census Bureau. Current Population Survey. Annual Estimates of the Population for the United States and States, and for Puerto Rico: April 1, 2000 to July 1, 2004 (NSTEST2004-01). http://www.census.gov/popest/states/NST-ann-est.html.

\section{Individual tax bases}

General sales and gross receipts

\section{Sources}

U.S. Census Bureau. 2002 Economic Census. Geographic Area Series Files 72:

Accommodation and Food Services; 51: Information; 81: Other Services; 71: Arts, Entertainment, and Recreation; and 44-45: Retail Trade. http://www.census.gov/econ/census02/guide/geosumm.htm.

Bureau of Economic Analysis. Regional Economic Accounts, State GSP Data for 2001 and 2002. http://www.bea.gov/bea/regional/gsp/.

\section{Methodology}

The tax base is the sum of retail trade, accommodations, food service, personal services, motion pictures, and arts and entertainment, minus gas, alcohol, gambling, and nonstore retail sales.

In calculating the retail trade base, missing/unreported data points are estimated using other proxies in the following way:

- Motion picture: The revenue figures for motion pictures are limited to motion pictures only (and not sound). Individual values for South Dakota and the District of Columbia are missing but are included in the national total. We distributed the undisclosed portion of the national total between South Dakota and District of Columbia using a combined weight of state populations and number of establishments.

- Gambling: Fourteen states (Alabama, Connecticut, Delaware, Georgia, Indiana, Maine, Massachusetts, Montana, New Hampshire, New Jersey, New Mexico, Rhode Island, Vermont, and Virginia) and the District of Columbia did not disclose gambling revenues but reported the number of establishments. The revenues for these states were reported 
in the U.S. totals. These 14 states and D.C. were not typical gambling states: while average number of establishments per state is 43 for the entire population of states, the states with the missing data had on average 10 establishments each. We estimated the revenues for each state by distributing the residual revenues (United States total minus all reported) by the number of establishments in each state.

- Beer, wine, and liquor sales: Four states (Arizona, Idaho, New Hampshire, and Utah) and the District of Columbia, all with relatively low numbers of establishments - on average 119 in each as opposed to the national average of 567-did not disclose revenue data (although they were included in the U.S. total). The residual revenues were distributed among these five areas in proportion to their reported number of establishments.

Following the studies for fiscal years 1997 and 1999, we take into account the growing importance of nonstore retail sales in certain states. Establishments that sell over the Internet or via mail-order catalogues generate most nonstore retail sales. If a firm engaging in such forms of commerce has property and employees, or both, located in a state, the state may tax items sold by the firm to resident households or resident businesses. Items sold to out-of-state purchasers, however, cannot be taxed, because of a lack of nexus. In estimates before 1996, all nonstore sales of goods were included in the retail sales. However, as the role of electronic commerce grows, including all nonstore sales would grossly overestimate the tax base. The Census Bureau estimates that e-commerce accounted for approximately 17 percent of all nonstore sales in FY 2002. One must account for out-of-state sales in this mix. Currently, no state-level data exist for the flow of electronic commerce. Therefore, the following decision rules were used to account for nonstore sales:

1. For each state, we computed a variable equal to the nationwide nonstore sales times the state's share of nationwide personal income.

2. We compared the actual nonstore sales in each state to this variable and applied the following rules:

- If actual nonstore sales were less than or equal to the variable then we assumed that all the nonstore sales were made to the residents of the state. Therefore, we kept the entire nonstore sales in the retail tax base.

- If the actual nonstore sales were greater than the variable then we assumed that the difference between the actual and estimated sales were made to nonresidents, and therefore should be excluded from the tax base.

\section{Selective sales: motor fuels}

\section{Source}

U.S. Department of Transportation, Federal Highway Administration. Highway Statistics 2002. Table MF2, "Motor Fuel Taxed 2002." Highway Statistics 2001. Table MF2, "Motor Fuel Taxed 2001."

\section{Methodology}

The tax base is the volume of taxed gallons of fuel for each state. 


\section{Selective sales: public utilities}

\section{Sources}

American Gas Association. Gas Facts 2002. Table 7-2, "Gas Utility Industry Sales Revenues, by State 1996-2002," page 56.

Edison Electric Institute. Statistical Yearbook of the Electric Utility Industry 2002 and 2003.

Table 8.6 (formerly table 59), "Total Electric Utility Industry, by State and Class of Service."

Federal Communications Commission. Industry Analysis and Competition Division.

Statistical Trends in Telephony, 2004 and 2003. Table 15.6, "Telephone Industry

Revenues by State." http://www.fcc.gov/wcb/iatd/trends.html.

\section{Methodology}

The tax base is the sum of revenues of all gas, electric, and telephone companies. For the telephone industry, which includes terrestrial and wireless telephony, the state revenues are the sum of interstate and intrastate revenues.

\section{Selective sales: insurance}

\section{Sources}

American Council on Life Insurance. Life Insurance Fact Book, 2003. Table 9.6, "Premium Receipts of U.S. Life Insurance Companies by State." http:/www.acli.com/NR/rdonlyres/ewe26md5wkec2waglxxvcdeb75rf4wgmox3lzfr2y fr3p6s3quwv6h5xxwh5c5bcs2usg64gm6s66o/In\%2bthe\%2bStates.pdf.

Insurance Information Institute. The Fact Book 2002 and 2003. "Direct Premiums Written by State." p. 25.

\section{Methodology}

The tax base is the direct written premiums (or premium receipts) for life, property, and casualty insurance.

\section{Selective sales: tobacco products}

\section{Source}

Orzechowski \& Walker, Virginia, USA. The Tax Burden on Tobacco, Historical Compilation, 2004, Volume 39. State Tax-Paid Cigarette Sales.

\section{Methodology}

The tax base is the number of packages of cigarettes sold. 


\section{Selective sales: alcoholic beverages}

\section{Sources}

National Institute on Alcohol Abuse and Alcoholism. Apparent per capita alcohol consumption: National, state, and regional trends, 1977-2002. Surveillance Report \#66. Table 2a, "Apparent alcohol consumption for states, census regions, and the United States, 2001," and table 2b, "Apparent alcohol consumption for states, census regions, and the United States, 2002." http://www.niaaa.nih.gov/publications/surveillance66/tab2b_02.htm, http://www.niaaa.nih.gov/publications/surveillance66/tab2a_02.htm.

Distilled Spirits Council of the United States (DISCUS). Public Revenues from Alcohol Beverages, 2003. Table 14.

\section{Methodology}

The tax base is the combined consumption in gallons of beer, wine, and distilled spirits. Because census tax data have only aggregate alcohol beverage tax collection values by state, a breakdown of tax collections by beverage type was obtained from DISCUS and used in the calculation of the representative rates.

\section{Selective sales: amusements}

\section{Source}

U.S. Census Bureau. Economic Census 2002. Retail Sales and Selected Service Receipts by State.

\section{Methodology}

The tax base is arts, entertainment, and recreation, plus motion pictures and exhibition, minus promoters of performing arts, sports, and similar events; minus agents/managers for artists, athletes, and other public figures; minus independent artists, writers, and performers; minus coin-operated amusement devices (except slots). Estimates for statelevel values for motion pictures, promoters, agents/managers, independent artists, and coinoperated amusement devices when data are missing are obtained by using the number of establishments as a proxy. Individual adjustment rates appear in the appendix tables.

\section{Selective sales: pari-mutuels}

\section{Source}

Christiansen Capital Advisors LLC. Gross Annual Wagers of the United States, 2001 and 2002.

\section{Methodology}

The tax base is the sum of dog racing, horseracing, and jai alai revenues bet within each state. 


\section{Licenses: motor vehicle registrations}

\section{Source}

U.S. Department of Transportation, Federal Highway Administration. Highway Statistics 2002 and 2001. Table MV-1, "State Motor-Vehicle Registrations."

\section{Methodology}

The tax base is the sum of private and commercial motor vehicle registrations in the state.

\section{Licenses: corporations}

\section{Source}

Internal Revenue Service. Internal Revenue Service Data Book. Table 3, "Number of Returns Filed, by type of Return and State, Fiscal Year 2002." http:/www.irs.gov/pub/irssoi/02db03nr.xls.

\section{Methodology}

The tax base is the total number of corporation licenses granted in the state. Separate numbers did not exist for Maryland and District of Columbia, so the combined figure is allotted by each state's personal income ratio.

\section{Licenses: motor vehicle operators}

\section{Source}

U.S. Department of Transportation, Federal Highway Administration, Highway Statistics 2002 and 2001. Table DL-22, "Total Licensed Drivers, by Age." http://www.fhwa.dot.gov/policy/ohim/hs02/xls/dl22.xls and http://www.fhwa.dot.gov/ohim/hs01/xls/dl22.xls.

\section{Methodology}

The tax base is the number of licenses in each state.

Licenses: fishing and hunting

\section{Source}

U.S. Department of the Interior. Fish and Wildlife Services, Division of Federal Aid, State and Fish Game Departments. Fishing License Data History. Table "Number of Paid Fishing License Holders, License Sales, and Cost to Anglers-Fiscal Year 2002." http://federalasst.fws.gov/license holders/Fishing License Data History.pdf.

\section{Methodology}

The tax base is the total number of licenses granted by each state.

\section{Individual income tax}

\section{Sources}

Bureau of Economic Analysis. Residency Adjustments by State, 2001-2002, http://www.bea.gov/bea/ARTICLES/2004/05May/0504RevSPI.pdf. 
Government of the District of Columbia. Tax Rates and Tax Burdens in the District of Columbia- A Nationwide Comparison 2002. Table 15, "Individual Income Tax. Exemption Amounts for Singles Returns, Joint Returns, Head of Household Returns and Dependents."

Internal Revenue Service. Statistics of Income, "Individual Income Tax Information by State, 2000, 2001 and 2002. Adjusted Gross Income, Adjustments and Adjustments for Residency by State and Number of Dependents, Single Returns, Joint Returns and Head of Household Returns

\section{Methodology}

The tax base is the adjusted gross income (AGI) modified for federal adjustment amounts and residency adjustments, net of exemptions. The formula of this modification is as follows:

Individual Income Tax Base $=$

$$
\text { AGI + Adjustments - Adjustments for Residence - Exemptions }
$$

We obtained the exemption values using the following steps:

- For each state, we found the exemption level for each type of exemption.

- For each type of exemption, we calculated the weighted average of the exemption level for all states. We used per capita income tax receipts as the weight.

- We used this weighted average to calculate amount of exemptions by state. To do so, for each exemption type, we multiplied the weighted average exemption by the number of exemptions in that state. Summing this through all exemption types, we obtained the total exemption value for that state.

- In calculating the exemptions and AGI for FY 2002, we use data from calendar years 2001 and 2002. However, state-level filing-type data for the calendar year 2002 did not report exemptions for dependents and the return numbers for single and head of household filers (it only had data on joint returns). Additionally, compared with the data reported for previous years, the 2002 data presented fewer income brackets. As a result, the following adjustments were made:

o Adjustments for income brackets: The 2002 data on AGI did not report the following categories: Breakeven and loss, AGI between $\$ 0$ and $\$ 10,000$, and AGI between $\$ 10,000$ and $\$ 20,000$. Additionally, AGI for income levels above $\$ 200,000$ were pooled together. In calculating the total income for FY 2002, the AGI amounts for these categories were calculated using the ratios observed in calendar year 2001. For example, to calculate the AGI for income levels 10,000 to 20,000, we used the following steps:

- Use the 2001 data to calculate the ratio of AGI for the $\$ 10,000-\$ 20,000$ bracket to the total AGI reported for the $\$ 0-\$ 20,000$ bracket.

- Multiply this ratio to the AGI 2002 to estimate 2002 total AGI reported for this category. 
- Repeat these steps for all income levels not reported in 2002 (but reported in 2001). The FY 2002 data use the estimates calculated for 2002 as well as AGI numbers for 2001.

o Adjustments for different filing categories, number of exemptions: Because many filing categories were missing from the 2002 data, the number of returns and exemptions filed in 2001 was used as a proxy for the entire fiscal year. However, 2001 data did not contain the number of dependency exemptions. To calculate this number, we used the 2000 returns as proxy:

- We calculated the ratio of dependency exemptions to the total number of returns filed, for each income bracket for calendar year 2000. Then, we used this ratio to calculate the total number of dependent claims for each income bracket for 2001.

- To estimate the FY2002 data, we first calculated the proportion of different filing types and exemption numbers to the number of total returns for 2001.

- Using these proportions, we estimated the number of returns by type for 2002. We used the 2001 and 2002 data to calculate FY2002 data.

o Adjustments for "total adjustments to AGI": Because the 2002 data didn't include the total adjustments to AGI, we used the ratio of adjustments to total AGI for each state for 2001, and then multiplied the state-level AGI data for FY 2002 with this ratio to calculate the adjustments for FY 2002.

\section{Corporate income tax}

\section{Sources}

U.S. Bureau of the Census. 2002 Economic Census. Payroll and Receipts Data by Sector by State.

Bureau of Economic Analysis. National Income and Product Accounts. Table 6.17c, "Corporate Profits by Industry Group.”

\section{Methodology}

The tax base is the amount of corporate profits for each state. Because state-level corporate data were not available, the national data were allocated to the states. This involved a multistep process:

1. We collected the 2002 annual receipts and payroll data by state by industry from the Economic Census and 2002 national corporate profits by industry from the BEA.

2. We calculated the percent of each industry located in each state:

o For each industry, we calculated state-level receipts ratios (state receipts divided by the total receipts in that industry).

o For each industry, we calculated state-level payroll ratios (state payroll divided by the total payroll in that industry).

3. We used the ratios calculated in step 2 to allocate national corporate profits in a given industry to each state. In estimating the profits, the receipts were weighted once and 
payroll was weighted twice. Thus, the weight equals $\left(\frac{2 \cdot \text { Payroll }_{s, i}}{\sum_{s} \text { Payroll }_{i}}+\frac{\text { Receipts }_{s, i}}{\sum_{s} \text { Receipts }_{i}}\right) / 3$, where $s$ and $i$ index states and industries, respectively.

4. We summed the corporate profits across different industries in a given state to obtain the total corporate profits in that state.

Aggregate profit numbers for construction, mining, and manufacturing are not available for the United States, so we used the sum of those numbers as one industry.

Disaggregated receipt numbers for finance, information, and utilities are not available at the state level, so we excluded the receipt ratios for those industries in the final apportionment of corporate profits. Finally, when receipt numbers were not available for a given industry at a state level, we used number of establishments to apportion the national receipts net of available numbers. The agriculture/forestry data for both payroll and receipts are missing in the census, so we used the average payroll ratio of all industries for these industries. After these four adjustments, $\$ 5$ million in profits remained unaccounted for. This residual was distributed across states using the average payroll ratio.

\section{Property tax}

\section{Sources}

American Gas Association. Gas Facts: 2002 Data. Table 5-2, "Gas Utility Industry Miles of Pipeline and Main, by State, 1990-2003."

Department of Energy. Energy Information Administration. Annual Electric Generator Report (EIA-860)

Federal Communications Commission. Common Carrier Bureau. 2001-2002 Statistics of Communication Common Carriers, Table 2.4, "Access Lines." http://www.fcc.gov/Bureaus/Common_Carrier/Reports/FCCState_Link/SOCC/01soc c.pdf.

Freddie Mac Index, http://www.freddiemac.com/finance/cmhpi/release.htm.

Internal Revenue Service. 2002. "Depreciable assets, Depletable assets and Land, Returns of active corporations," http://www.irs.gov/pub/irs-soi/02co06nr.xls.

Internal Revenue Service. "Depletable, Depreciable, and Land Assets in the Utility Sector 2002.” Returns of Active Corporations. http://www.irs.gov/pub/irs-soi/02co06nr.xls.

Internal Revenue Service. "Depreciable Assets in the Utility Sector, by Industry 2002." Returns of Active Corporations by Minor Industry. http://www.irs.gov/pub/irssoi/02co01nr.xls.

U.S. Bureau of the Census, Characteristics of New Housing: 2001, 2002. "Average and Median Square Feet of Floor Area, by Category of House, Location and Type of Financing" 
and "Sales Price of Houses, by Location and Type of Financing, and Price per Square Foot of Floor Area, by Location."

U.S. Census Bureau. Statistical Abstract of the United States (various years). "Construction Contracts-Value by State."

U.S. Census Bureau. Decennial Census. Summary Tape File 3 on CD-ROM. Table H-86, "Aggregate Value by Mortgage Status."

U.S. Census Bureau. Decennial Census. Summary Tape File 3 on CD-ROM. Table H-64, "Aggregate Gross Rent."

U.S. Census Bureau. 2002 Economic Census. Sector Receipt Totals by State. http://www.census.gov/econ/census02/guide/geosumm.htm.

Bureau of Economic Analysis. Regional Economic Accounts, 2002. Regional Personal Income by Industry. http://www.bea.doc.gov/bea/regional/spi/.

U.S. Department of Agriculture. National Agricultural Statistics Service. "Farms and Land in Farms: by State and United States, 2000_2002," http://usda.mannlib.cornell.edu/reports/nassr/other/zfl-bb/fmno0203.txt.

U.S. Department of Agriculture. National Agricultural Statistics Service. "Farm Real Estate: Average Value per Acre, by Region and State." http://www.usda.gov/nass/pubs/stathigh/2003/tables/economics.htm

\section{Methodology}

The tax base is the total property value in the state. Total property value consists of farm property, residential property, corporate property, and utility property including all exemptions.

State agencies vary widely on the data they report on the total value of property in the state-some include the total value of all property, others of only taxable property, and some only the assessed value of taxable property. For calculating tax capacity, one needs the total potential property tax base, and not all states report this value. The methodology below outlines our alternative measure of taxable property base. The total property calculations matched the state's estimates in many cases.

The tax base is the sum of utility, corporate, residential, and farm property values.

Utility property: Property for the utility sector in each state is the composite of the property (depreciable and depletable assets less depreciation, and land) in the gas, electric, and telephone industries. Assets for each sector are allocated by relative network size (state's share of gas pipeline, electrical generating capacity, and access telephone lines, respectively). In calculating the total property value, each asset base is weighted by its share of depreciable assets that make up the total of the utility industry: 
- The share of nationwide depreciable property allocated across the gas, electric, and telephone industries is obtained from the IRS's 2002 Returns of Active Corporations by Minor Industry.

- The nationwide industry shares are applied to the total amount of utility property (combination of depreciable and depletable assets less depreciation and depletion, and land) to obtain national property estimates for each sector.

- Total property value for each sector is allocated across states using the network size proxy.

- Summing the state-level property values across the three utility sectors yield the total utility property value estimate for that state.

Corporate property: Corporate property consists of depreciable assets, depletable assets (both minus accumulated depreciation), and land. For 19 broad industry sectors, the amount of corporate property nationwide is allocated across states by calculating each state's share of the nationwide sector total. Subject to some inconsistencies noted below, each state's share is estimated by calculating the share of each sector's total personal income earned in that state. All sectors for each state were then added together to obtain an estimate of total corporate property by state.

- Missing personal income estimates for the accommodation and food services, mining, other services, and transportation and warehousing sectors are substituted with each state's calculated share of industry receipts from the 2002 Economic Census.

- Missing personal income estimates for the information and utility sectors are found by allocating the remaining share of a sector's income by each state's share of nationwide personal income totals.

- Missing agriculture and forestry sector personal income estimates are substituted with share estimates from the 1999 study as receipt totals are unavailable and total state personal income share is not a good proxy for this sector.

Residential property: In theory, this class of property should include all residential property in the state-including exemptions. The estimate was obtained following the following steps:

- To account for inflation in the housing market, we calculated the growth in the Freddie Mac index for each state from 2000 to 2002 and from 2001 to 2002.

- We used the 2000 to 2002 growth rate to inflate 2000 Total Aggregate Owner-Occupied Housing Property Values and the 2000 Asset Value from Rental Property to 2002 levels.

- We calculated the 2000 Asset values by multiplying Aggregate Gross Rent by 12 (to annualize it), and then dividing Annualized Aggregate Gross Rent by 2 (to obtain Net Operating Income) and then dividing Net Operating Income by .09 (to obtain the Net Present Value with interest rate equal to 9 percent).

- In order to account for the new housing constructed in 2001, we summed the value of residential construction contracts for this year and inflated this figure by the Freddie Mac Index. We used this figure and 2002 residential construction values to calculate the residential contract values for FY 2002. 
- The next step involved adjusting for land value. To do so, we calculated the ratio of the value of construction to total value of the property (construction plus land), and divided the value of construction for FY 2002 with this ratio.

- First, we found the average value of property by multiplying average square feet of floor area by the average price per square foot, by region.

- Then, we divided this product by the average sales price of one-family houses to arrive at the value of construction to total value.

- The last step involves adding together the housing stock from 2000 (both owneroccupied and rental) and the new construction for 2001 and FY 2002.

Farm property: Farm property is the estimated market value of land and buildings on farms for FY 2002. Total market value of this land is obtained by multiplying the total number of acres of farmland in each state by the average value per acre of farmland as of January 1 , 2002. Data for average value per acre are missing for Alaska and Hawaii; the farm values for these states were increased by the 48 -state growth rate in the market value of farm land and buildings between 1999 and 2002.

We compared the estimates for total property value (sum of utility, corporate, residential and farm property values) with the estimates of property values obtained from state agencies and chose the larger value.

\section{Death and gift tax}

\section{Sources}

Internal Revenue Service. Internal Revenue Service Data Book 2002. Publication 55B. Table 6, "Internal Revenue Gross Collections, by State, Fiscal Year 2002." http://www.irs.gov/taxstats/bustaxstats/article/0,id=136474,00.html.

U.S. Census Bureau. "State and Local Government Tax Collections, 2002." http://www.census.gov/govs/www/statetax.html

\section{Methodology}

The tax base is the sum of all federal death and gift collections for each state. As the federal taxes are applied uniformly across all states, this provides a valid measure of the magnitude of each state's base. The data for Maryland and District of Columbia collections are separated using the allocation of personal income across the two geographies.

\section{Severance taxes}

\section{Sources}

Energy Information Administration. Petroleum Supply Annual 2003, Volume 1. Table C1, "Revised Crude Oil Production by PAD District and State." http://www.eia.doe.gov/pub/oil_gas/petroleum/data_publications/petroleum_supply_ annual/psa_volume1/historical/2003/pdf/volume1_appendix_c.pdf. 
Energy Information Administration. Annual Coal Report 2002 and 2003. Table 1, "Coal

Production and Number of Mines by State and Mine Type, 2003, 2002," and from

Table 28, "Average Open Market Sales Price of Coal by State and Mine Type, 2003, 2002.” http://www.eia.doe.gov/cneaf/coal/page/acr/acr_sum.html.

Energy Information Administration. Natural Gas Annual 2001 and 2002. Table 6, "Wellhead Value and Marketed Production of Natural Gas by State, 1998-2002."

http://www.eia.doe.gov/pub/oil_gas/natural_gas/data_publications/natural_gas_annua 1/historical/2002/pdf/table_006.pdf,

http://www.eia.doe.gov/pub/oil_gas/natural_gas/data_publications/natural_gas_annua 1/historical/2001/pdf/table_006.pdf.

Energy Information Administration. Minerals Yearbook 2001 and 2002. Table 5, "Nonfuel Mineral Production in the United States, by State."

Energy Petroleum. Marketing Monthly March 2003.

http://www.eia.doe.gov/pub/oil_gas/petroleum/data_publications/petroleum_supply_ annual/psa_volume1/historical/2002/pdf/volume1_appendix_c.pdf .

\section{Methodology}

The tax base is the sum of the value of oil production, coal production, natural gas production, and nonfuel mineral production.

- The price data for crude oil are missing for a number of states. Alaska's price was determined by weighting the North Slope and South prices by production. For the remaining states (Arizona, Florida, Missouri, Nevada, Tennessee, and Virginia) the average price for the PAD (Petroleum Administration for Defense) district is used.

- Coal price data are also missing for Alaska, Arizona, Arkansas, Kansas, Louisiana, Maine, and Mississippi. To calculate this value, we used the average price for the fiscal year from the same census division.

\section{All other taxes}

\section{Source}

Bureau of Economic Analysis. Regional Economic Accounts. "State Personal Income annual estimates." http://www.bea.gov/bea/regional/spi/.

\section{Methodology}

The tax base is the personal income for each state. The tax revenue for all other taxes consists of the following categories of tax revenue from Census of Governments (see "State and Local Finance Data" above for source information): Other Selective Sales (T-29), Amusement Licenses (T-21), Alcohol Licenses (T-20), Public Utility Licenses (T-27), Occupational/Business Licenses (T-28), Other Licenses (T-19), Documentary and Stock Transfers (T-51), and Not Elsewhere Classified (T-99). 


\section{Bases for individual user charges/fees and other nontax revenues}

\section{Lotteries}

Sources

U.S. Census Bureau. Census of Governments. "Income and Apportionment of StateAdministered Lottery Funds: 2002."

http://www.census.gov/govs/state/02lottery.html.

Bureau of Economic Analysis. Regional Economic Accounts. "Disposable Personal Income.” http://www.bea.gov/bea/regional/spi/default.cfm?satable=summary.

U.S. Census Bureau. 2002 American Community Survey. Table P007, "Households." http://factfinder.census.gov/servlet/DatasetMainPageServlet?_lang=en\&_ts=1702672 74770\&_ds_name=ACS_2002_EST_G00_\&_program=ACS.

U.S. Census Bureau. 2002 and 2003 Current Population Survey.

\section{Methodology}

The base is the gross revenue from the sale of lottery tickets. A representative base for each state is estimated through a log-form cross-sectional regression of state-level economic and demographic data on gross lottery sales. The regression is unweighted, so each state is equally influential in the regression. For each state's estimate, predicted values are used as the base.

The regression specifications are also applied to states without lotteries. A base is calculated for these states even though lottery revenues (hence the revenue effort) obviously equal zero. (There were 12 states without lotteries in FY 2002: Alabama, Alaska, Arkansas, Hawaii, Mississippi, Nevada, North Carolina, North Dakota, Oklahoma, Tennessee, Utah, and Wyoming.) In such states, the prize percentage is assumed to be the prevailing national average and the administrative costs are the assumed to be the prevailing regional averages. The resulting base for each state is an estimate of what a state would raise in revenue if it adopted a "nationally representative" lottery.

The decision to assign lottery revenue bases to states without lotteries was made after careful consideration. We might be assigning "capacity" to states that would never choose to exercise this capacity, because of local preferences (Utah, for example) or because they have chosen a different method of taxing a similar base (for example, Nevada's high amusement tax). But assigning these states a potential base helps maintain uniformity across states (and indeed, the same approach is used for other taxes). Some states choose not to use an income or sales tax, yet the economic activity underlying these potential revenues should be accounted for. Additionally, since FY1991 (the last time for which lottery revenue capacity of states was calculated), five states have implemented lotteries, suggesting that the decision to exploit an underlying lottery base is not that uncommon. 
In FY 2002, 38 states had lotteries. Three of these states-Delaware, West Virginia, and South Dakota-had significantly different revenue and cost structures in their lottery programs because they collected a relatively larger share of revenues from video lottery terminals. As a result, these states' lottery data have been omitted from the regression and each state's representative base is estimated as if it did not have a lottery.

Variables and their sources are listed below.

\section{Dependent variable}

Gross lottery revenues per household - logged (Census of Governments and American Community Survey)

\section{Independent variables}

Disposable income per household - logged (Bureau of Economic Analysis)

Percent of population 18+ in a metro area (Current Population Survey)

Percent of population with at least some college, 18+ (Current Population Survey)

Percent of $18+$ population that is $65+$ (Current Population Survey)

Percent of lottery revenues used for prizes (Census of Governments)

Lottery administrative expenditures per household - logged (Census of

Governments and American Community Survey)

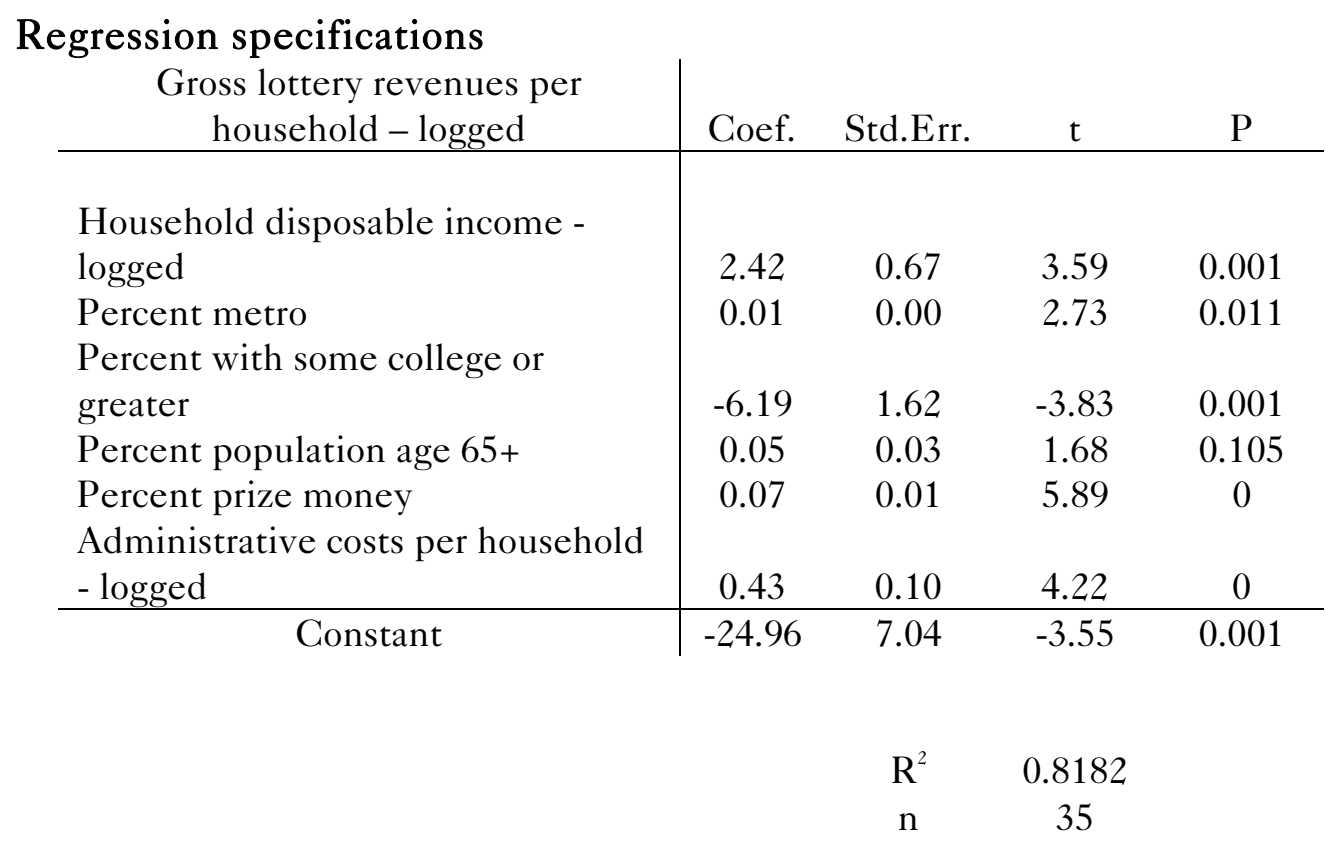

\section{General charges}

\section{Sources}

U.S. Census Bureau. Annual Survey of Government Finances, State and Local Finances by Type of Government. http://ftp2.census.gov/govs/estimate/02statetypecd.zip. 
Bureau of Economic Analysis. Regional Economic Accounts. State Personal Income annual estimates. http://www.bea.gov/bea/regional/spi/.

\section{Methodology}

The revenue base for each state is the personal income in each state. Revenues for General User Charges consist of the following categories from Census of Governments: Air Transportation (A01), Miscellaneous Commerce Activity (A03), Total Education Charges (A09, A10, A12, A16, A18, A21), Hospital Charges (A36), Charges for highways and tollroads (A44, A45), Housing and Community Development (A50); Charges on Natural Resources (A54, A56, A59), Parking (A60), Parks and Recreation (A61), Sewerage (A80), Waste Management (A81), Water Transport (A87), and all other NEG (A99).

\section{Other nontax revenues (miscellaneous general revenues)}

\section{Sources}

U.S. Census. Bureau Annual Survey of Government Finances, State and Local Finances by Type of Government. http://ftp2.census.gov/govs/estimate/02statetypecd.zip.

Bureau of Economic Analysis. Regional Economic Accounts. State Personal Income annual estimates. http://www.bea.gov/bea/regional/spi/.

\section{Methodology}

The revenue base for each state is the personal income in each state. Revenues for Miscellaneous General Revenues consist of the following categories from Census of Governments: Property Sale from Housing/Community Development (U10), Other Property Sale (U11), Interest Revenue (U20), Fines and Forfeits (U30), Rents (U40) and Royalties (U41), Private Donations (U50), and Miscellaneous General Revenue NEC (U99). 


\section{Appendix C: Data sources and methodology for representative expenditure system (RES), 2002}

This appendix details the representative expenditure system, including all data sources, construction of workload measures, and adjustments and estimations used to obtain the fiscal year 2002 results. For earlier methodologies, see Robert Rafuse's Representative Expenditures: Addressing the Neglected Dimension of Fiscal Capacity, Advisory Commission on Intergovernmental Relations, M-174, December 1990, and Tannenwald (2002) and Tannenwald and Turner (2004).

The RES system provides normalized expenditure estimates for a given unit of public services provided. This involves several steps:

First, one must identify and define categories of expenditures principally influenced by factors other than state populations. This study includes six such factors: elementary and secondary education, higher education, public welfare, health and hospitals, highways, and police and corrections. In 2002, these categories accounted for 71 percent of all direct general expenditures for state and local governments.

Next, one must define measurable "workload" factors—other than the price of inputs—that affect the cost of providing the service. For example, the workload measures for highway expenditures are the number of vehicle miles traveled (capturing maintenance costs due to traffic) and total lane miles (measuring maintenance costs due to time and exposure). With multiple workload measures, the composite workload measure is constructed with a weighted average. In this example, based on engineering estimates, vehicle miles traveled is weighted 4.71 times more than total lane miles.

For each expenditure item, we multiply the national expenditure level by the workload factor in each state to estimate what it would have cost the state to provide one workloadmeasure unit of services. However, the cost of providing the services associated with this expenditure item varies across states because of cross-state variations in labor and other input costs. We account for these differences across states by controlling for the input prices used in the provision of public services; the particulars of this methodology are outlined below in the input-cost section.

The total expenditure need in a state is the sum of expenditure needs across different expenditure items. Indexing the per capita expenditure need to the national average (set at 100) gives us an index of expenditure need - the primary index used in the RES system.

The remainder of this appendix details the data sources and workloads used in the RES 2002 results. 


\section{2 state and local expenditure data}

\section{Source}

U.S. Census. Annual Survey of State and Local Government Finances, 2001-02. April 2006.

http://www.census.gov/govs/www/estimate02.html

\section{Input-cost index data}

\section{Sources}

U.S. Census Bureau. Economic Census 2002. Earnings by Occupation and Education. http://www.census.gov/hhes/income/earnings/earnings.html.

U.S. Census Bureau. State and Local Government Employment and Payroll, 2002. March 2002 State and Local Government Payroll Data by Function.

\section{Methodology}

The input-cost adjustment normalizes for cost differentials across states. First, we tabulated the earnings for males age 45-64 by state and by educational attainment. Next, we created a state-by-state labor cost index by weighting each state's median earnings for each education level by the national distribution of educational attainment.

For each expenditure item, we constructed an input-cost index for each state. We annualized the March payroll and then divided this number by the total expenditures for each item. This gave us the ratio of payroll costs in total expenditures for each expenditure item. Following previous studies, we assumed that payroll expenditures constitute 75 percent of all compensation expenditures. Thus, we calculated the share of compensation in total expenditure by dividing the payroll's share by 0.75 . Finally, for each expenditure item, we multiplied this compensation percentage by the labor cost index number for that state and then added to the non-compensation percentage of costs multiplied by 100 .

Consequently, for a given state

$$
\text { Input Cost Index }=\operatorname{comp} \% \text { * labindex }+((1-\operatorname{comp} \%) * 100)
$$

where comp\% is the compensation as percentage of total expenditure for a given expenditure item, and labindex is the state's labor cost index.

\section{Calculating representative expenditures}

To calculate representative expenditures by function, we multiplied, for each expenditure item, the state's workload measure by the total national expenditure for that items and the state's input-cost index function. Dividing this number by the state population yields the per capita adjusted expenditure need for each function. Then, we normalized the expenditure need estimates so the expenditure need summed over all states equals the actual national expenditures for each item. 


\title{
Data for estimating representative expenditures
}

\author{
Public welfare
}

Sources

U.S. Census Bureau. Current Population Survey, Annual Estimates of the Population for the United States and States, and for Puerto Rico: April 1, 2000 to July 1, 2004 (NSTEST2004-01). http://www.census.gov/popest/states/NST-ann-est.html.

U.S. Census Bureau. 2002 American Community Survey. Table P114, "Poverty Status in the Past 12 Months by Sex by Age."

http://factfinder.census.gov/servlet/DatasetMainPageServlet?_lang=en\&_ts=1702672 74770\&_ds_name=ACS_2002_EST_G00_\&_program=ACS.

U.S. Census Bureau. Current Population Survey. Annual Social and Economic Supplements, Historical Poverty Table 19.

http://www.census.gov/hhes/www/poverty/histpov/hstpov19.html.

The Henry J. Kaiser Family Foundation. Statehealthfacts.org.

\section{Methodology}

The public welfare workload measure is a composite measure of both a state's share of total population in poverty and its share of elderly population (age $75+$ ) in poverty, where the former is weighted by 75 percent and the later is weighted by 25 percent.

The weighting is drawn from the fact that in 2002, roughly two-thirds of all public welfare spending nationwide was spent on medical vendor payments for Medicaid (a stateadministered program), of which roughly 40 percent was spent on the elderly. This is an update of the old methodology, which took state's share of total population in poverty as the workload measure.

\section{Elementary and secondary education}

\section{Sources}

U.S. Census Bureau. State Population Estimates. State Single Year of Age and Sex Population Estimates: April 1, 2000 to July 1, 2004.

http://www.census.gov/popest/datasets.html\#mrd.

U.S. Census Bureau. Current Population Survey 2002 March Supplement, Poverty in the United States. Table 25, "Poverty Status by State and Ten Large Metropolitan Areas in 2001, People Under 18." http://ferret.bls.census.gov/macro/032002/pov/new25_003.htm.

U.S. Census Bureau. Current Population Survey 2003 March Supplement, Poverty in the United States. Table POV46, "Poverty Status by State, People under 18 Years of Age, Weighted Person Count, 100 and 125 Percent of Poverty." http://ferret.bls.census.gov/macro/032003/pov/new46_100125_03.htm. 
U.S. Department of Education. National Center for Education Statistics. Characteristics of Private Schools in the United States: Results From the 2001-2002 Private School Universe Survey. Table 26, "Number of private schools, students, full-time-equivalent (FTE) teachers, and high school graduates, by state: United States, 2001-02." http://nces.ed.gov/pubs2005/2005305.pdf.

\section{Methodology}

The workload measure for elementary and secondary education allocates the total private school enrollment between primary and secondary schools using the overall ratios of elementary and secondary school cohorts. The number of potential public school students is calculated as the primary and secondary cohorts net of private enrollments.

Past editions of this study used Rafuse's original assumptions that the primary to secondary per pupil cost ratio is 0.60 and that the children in poverty cost 25 percent more to educate. The per pupil costs at the primary level have been increasing over the past decade-from 1999 to 2005, this ratio climbed from 0.79 to 0.86. (See UNESCO Institute of Statistics, Education Database, Table 19, "Finance Indicators by ISCED Level," http://stats.uis.unesco.org/TableViewer/tableView.aspx?ReportId=219.)

In this edition, we assume that the cost ratio is 0.85 . Past studies that used Title I have typically found that the cost of educating the poor requires a 20 to 25 percent premium. However, given the costs of compensatory education, special education, and language education programs, supplemental services, plus all other costs related to operating a school in a poor area such as transportation, school lunch, theft, and vandalism, the premium is possibly much larger. In this study, we assume that educating a poor student is likely to cost 50 percent more (Rothstein 2001).

The education cost index for each state is calculated using the following formula:

$$
(1+.5 p)(0.85 e+s)
$$

where $p$ is the percentage of children under 18 in poverty, $e$ is the number of elementary students, and $s$ is the number of secondary students.

The workload measure is each state's share of the education cost index.

\section{Higher education}

\section{Sources}

U.S. Census Bureau. State Population Estimates. State Single Year of Age and Sex Population Estimates: April 1, 2000 to July 1, 2004.

http://www.census.gov/popest/states/files/SC-EST2004-AGESEX_CIV.csv.

U.S. Department of Education. National Center for Education Statistics. Digest of Education Statistics. Table 176, "Total fall enrollment in degree-granting institutions, by attendance status, age, and sex: Selected years, 1970 to 2013." http://nces.ed.gov/programs/digest/d03/tables/dt176.asp. 


\section{Methodology}

First, we calculated the national college enrollments for age groups $14-17,18-24,25-34$, and $35+$, assuming three part-time students equal one full-time-equivalent student. Then we weighed each state's population in each of these age groups by the national net enrollment ratio in that group to estimate the college population in each state. The workload measure is each state's share of the estimated college population.

\section{Health and hospitals}

\section{Sources}

U.S. Census Bureau. Current Population Survey. Annual Estimates of the Population for the United States and States, and for Puerto Rico: April 1, 2000 to July 1, 2004 (NSTEST2004-01). http://www.census.gov/popest/states/NST-ann-est.html.

U.S. Census Bureau. Current Population Survey, Annual Demographic Survey March Supplements for 2001, 2002 and 2003. HINC-01: Selected Characteristics of Households by Total Money Income.

Social Security Administration. Social Security Bulletin, Annual Statistical Supplement 2002. Table 5.J1, "Estimated total benefits paid, by program and state or other area, 2001. http://www.ssa.gov/policy/docs/statcomps/supplement/2002/5j.pdf.

\section{Methodology}

To calculate each state's share of low-income families, we calculated the ratio of national household income averaged among the bottom fourth and fifth quintiles (averaged for 2000-02) to state household income averaged among the bottom fourth and fifth quintiles. Then we multiplied this ratio by the state's share of population to obtain a final measure of poverty. This methodology differs from the FY 1999 study, which analyzed family income quintiles, while this study looks at household income quintiles.

The workload measure is the equally weighted average of state's share of total population, state's share of work-disabled population, and state's share of low-income families.

\section{Highways}

\section{Sources}

Federal Highway Administration. Highways Statistics 2001, and 2002. For both years, Table VM-2M, "Annual Vehicle-Miles of Travel." http://www.fhwa.dot.gov/policy/ohpi/qftravel.htm.

Federal Highway Administration. Highways Statistics 2001 and 2002. For both years, Table HM-60, "Rural and urban lane-miles, estimated."

\section{Methodology}

The workload measure is calculated as 0.825 times each state's share of vehicle-miles plus 0.175 times state's share of lane-mileage. These weightings are based on the GAO Report cited in Rafuse (1990a). 


\section{Police and corrections}

\section{Sources}

U.S. Census Bureau. State Population Estimates. State Single Year of Age and Sex Population Estimates: April 1, 2000 to July 1, 2004.

U.S. Census Bureau and Federal Bureau of Investigation. Crime in the United States 2001 and 2002. For both years, Table 5, "Index of Crime, by state."

http://www.fbi.gov/ucr/01cius.htm and http://www.fbi.gov/ucr/02cius.htm

\section{Methodology}

The workload measure is the equally weighted average of each state's share of total population, state's share of population age 18-24, and state's share of murders.

Other categories of expenditures: Environment and housing, interest on general debt, governmental administration, and all other direct general expenditures

\section{Source}

U.S. Census Bureau. Current Population Survey, Annual Estimates of the Population for the United States and States, and for Puerto Rico: April 1, 2000 to July 1, 2004 (NSTEST2004-01). http://www.census.gov/popest/states/NST-ann-est.html

\section{Methodology}

The workload measure is each state's share of the total 2002 U.S. population 


\section{Appendix D: Data tables}

Table Dı. State and local government finances by level of government, FY2002

\begin{tabular}{|c|c|c|c|}
\hline Description & $\begin{array}{l}\text { State and local government } \\
\text { amount }^{\mathrm{a}}\end{array}$ & $\begin{array}{l}\text { State government } \\
\text { amount }\end{array}$ & $\begin{array}{c}\text { Local government } \\
\text { amount }^{\mathrm{a}}\end{array}$ \\
\hline Population (April 1, 2000, in thousands) & 281,422 & $(\mathrm{X})$ & $(\mathrm{X})$ \\
\hline Revenue $^{\mathrm{a}}$ & $1,806,591,592$ & $1,097,045,283$ & $1,083,074,484$ \\
\hline General revenue $^{\mathrm{a}}$ & $1,684,879,080$ & $1,062,627,836$ & $995,779,419$ \\
\hline Intergovernmental revenue $^{a}$ & $360,546,218$ & $335,433,606$ & $398,640,787$ \\
\hline From federal government & $360,546,218$ & $317,582,530$ & $42,963,688$ \\
\hline From state government & $\mathrm{X}$ & $\mathrm{X}$ & $355,677,099$ \\
\hline From local government ${ }^{a}$ & $\mathrm{X}$ & $17,851,076$ & $\mathrm{X}$ \\
\hline General revenue from own sources & $1,324,332,862$ & $727,194,230$ & $597,138,632$ \\
\hline Taxes & $905,100,802$ & $535,191,161$ & $369,909,641$ \\
\hline Property & $279,191,478$ & $9,702,385$ & $269,489,093$ \\
\hline Sales and gross receipts & $324,122,506$ & $262,360,613$ & $61,761,893$ \\
\hline General sales & $222,986,687$ & $179,665,257$ & $43,321,430$ \\
\hline Selective sales & $101,135,819$ & $82,695,356$ & $18,440,463$ \\
\hline Motor fuel & $33,044,249$ & $31,968,036$ & $1,076,213$ \\
\hline Alcoholic beverage & $4,600,156$ & $4,249,208$ & 350,948 \\
\hline Tobacco products & $9,092,865$ & $8,902,018$ & 190,847 \\
\hline Public utilities & $20,293,723$ & $10,287,949$ & $10,005,774$ \\
\hline Other selective sales & $34,104,826$ & $27,288,145$ & $6,816,681$ \\
\hline Individual income & $202,832,254$ & $185,646,573$ & $17,185,681$ \\
\hline Corporate income & $28,151,862$ & $25,123,137$ & $3,028,725$ \\
\hline License taxes & $36,716,191$ & $35,391,102$ & $1,325,089$ \\
\hline Other taxes & $34,086,511$ & $16,967,351$ & $17,119,160$ \\
\hline Charges and miscellaneous general revenue & $419,232,060$ & $192,003,069$ & $227,228,991$ \\
\hline Current charges & $253,189,078$ & $100,213,156$ & $152,975,922$ \\
\hline Education & $72,290,510$ & $55,056,005$ & $17,234,505$ \\
\hline Hospitals & $65,404,087$ & $24,352,132$ & $41,051,955$ \\
\hline Highways & $8,196,456$ & $5,088,978$ & $3,107,478$ \\
\hline Air transportation (airports) & $12,330,615$ & 791,614 & $11,539,001$ \\
\hline Parking facilities & $1,402,243$ & - & $1,402,243$ \\
\hline Sea and inland port facilities & $2,685,135$ & 735,873 & $1,949,262$ \\
\hline Natural resources & $3,001,013$ & $2,115,202$ & 885,811 \\
\hline Parks and recreation & $7,021,178$ & $1,199,448$ & $5,821,730$ \\
\hline Housing and community development & $4,295,737$ & 529,252 & $3,766,485$ \\
\hline Sewerage & $27,112,453$ & 33,643 & $27,078,810$ \\
\hline Solid waste management & $11,192,000$ & 369,854 & $10,822,146$ \\
\hline Other charges & $38,257,651$ & $9,941,155$ & $28,316,496$ \\
\hline Miscellaneous general revenue & $166,042,982$ & $91,789,913$ & $74,253,069$ \\
\hline Other than general revenue & $121,712,512$ & $34,417,447$ & $87,295,065$ \\
\hline Utility revenue & $102,352,097$ & $11,935,400$ & $90,416,697$ \\
\hline Water supply & $33,236,410$ & 159,309 & $33,077,101$ \\
\hline Electric power & $54,403,809$ & $10,102,135$ & $44,301,674$ \\
\hline Gas supply & $5,761,745$ & 11,743 & $5,750,002$ \\
\hline Transit & $8,950,133$ & $1,662,213$ & $7,287,920$ \\
\hline Liquor store revenue & $5,065,107$ & $4,287,846$ & 777,261 \\
\hline Insurance trust revenue & $14,295,308$ & $18,194,201$ & $-3,898,893$ \\
\hline Expenditure $^{a}$ & $2,051,537,122$ & $1,282,852,187$ & $1,140,396,140$ \\
\hline Intergovernmental expenditure ${ }^{a}$ & $4,387,483$ & $364,847,087$ & $11,251,601$ \\
\hline Direct expenditure & $2,047,149,639$ & $918,005,100$ & $1,129,144,539$ \\
\hline Current operations & $1,499,243,299$ & $622,489,323$ & $876,753,976$ \\
\hline Capital outlay & $257,071,380$ & $89,767,123$ & $167,304,257$ \\
\hline
\end{tabular}




\begin{tabular}{|c|c|c|c|}
\hline Description & $\begin{array}{c}\text { State and local government } \\
\text { amount }^{2}\end{array}$ & $\begin{array}{l}\text { State government } \\
\text { amount }\end{array}$ & $\begin{array}{c}\text { Local government } \\
\text { amount }^{\mathrm{a}}\end{array}$ \\
\hline Assistance and subsidies & $33,109,840$ & $24,141,473$ & $8,968,367$ \\
\hline Interest on debt & $86,932,956$ & $33,200,760$ & $53,732,196$ \\
\hline Insurance benefits and repayments & $170,792,164$ & $148,406,421$ & $22,385,743$ \\
\hline Exhibit: Salaries and wages & $609,562,926$ & $167,841,309$ & $441,721,617$ \\
\hline Direct expenditure by function & 2,047,149,639 & $918,005,100$ & $1,129,144,539$ \\
\hline Direct general expenditure & $1,732,478,495$ & $745,821,802$ & $986,656,693$ \\
\hline \multicolumn{4}{|l|}{ Education services } \\
\hline Education & $594,694,004$ & $162,010,291$ & $432,683,713$ \\
\hline Libraries & $8,260,071$ & 419,049 & $7,841,022$ \\
\hline \multicolumn{4}{|l|}{ Social services and income maintenance } \\
\hline Public welfare & $281,176,211$ & $241,481,381$ & $39,694,830$ \\
\hline Hospitals & $87,609,368$ & $37,072,499$ & $50,536,869$ \\
\hline Health & $59,455,759$ & $30,160,528$ & $29,295,231$ \\
\hline Social insurance administration & $5,082,130$ & $5,072,948$ & 9,182 \\
\hline Veterans' services & 361,190 & 361,190 & - \\
\hline \multicolumn{4}{|l|}{ Transportation } \\
\hline Highways & $115,294,680$ & $71,055,977$ & $44,238,703$ \\
\hline Air transportation (airports) & $16,209,242$ & $1,170,391$ & $15,038,851$ \\
\hline Parking facilities & $1,122,971$ & - & $1,122,971$ \\
\hline Sea and inland port facilities & $3,571,052$ & $1,014,880$ & $2,556,172$ \\
\hline Transit subsidies & 625,569 & 304,225 & 321,344 \\
\hline \multicolumn{4}{|l|}{ Public safety } \\
\hline Police protection & $64,458,395$ & $9,407,598$ & $55,050,797$ \\
\hline Fire protection & $25,997,621$ & - & $25,997,621$ \\
\hline Correction & $54,615,236$ & $36,428,737$ & $18,186,499$ \\
\hline Protective inspection and regulation & $11,631,226$ & $7,873,548$ & $3,757,678$ \\
\hline \multicolumn{4}{|l|}{ Environment and housing: } \\
\hline Natural resources & $22,000,189$ & $16,588,299$ & $5,411,890$ \\
\hline Parks and recreation & $30,101,204$ & $4,952,534$ & $25,148,670$ \\
\hline Housing and community development & $31,622,757$ & $3,783,028$ & $27,839,729$ \\
\hline Sewerage & $31,257,197$ & $1,049,804$ & $30,207,393$ \\
\hline Solid waste management & $19,051,359$ & $2,736,496$ & $16,314,863$ \\
\hline \multicolumn{4}{|l|}{ Governmental administration: } \\
\hline Financial administration & $32,659,750$ & $18,939,795$ & $13,719,955$ \\
\hline Judicial and legal & $31,210,148$ & $14,415,793$ & $16,794,355$ \\
\hline General public buildings & $10,899,918$ & 2,632,930 & $8,266,988$ \\
\hline Other governmental administration & $18,009,148$ & $3,921,391$ & $14,087,757$ \\
\hline Interest on general debt & $75,287,295$ & $31,407,303$ & $43,879,992$ \\
\hline \multicolumn{4}{|l|}{ General expenditure, n.e.c. } \\
\hline Miscellaneous commercial activities & 419,421 & 360,176 & 59,245 \\
\hline Other and unallocable & $99,795,384$ & $41,201,011$ & $58,594,373$ \\
\hline Utility expenditure & $139,696,158$ & $20,278,852$ & $119,417,306$ \\
\hline Water supply & $40,555,413$ & 386,106 & $40,169,307$ \\
\hline Electric power & $55,952,337$ & $11,688,979$ & $44,263,358$ \\
\hline Gas supply & $5,720,135$ & 8,929 & $5,711,206$ \\
\hline Transit & $37,468,273$ & $8,194,838$ & $29,273,435$ \\
\hline Liquor store expenditure & $4,182,822$ & $3,498,025$ & 684,797 \\
\hline Insurance trust expenditure & $170,792,164$ & $148,406,421$ & $22,385,743$ \\
\hline Unemployment compensation & $42,195,724$ & $42,046,248$ & 149,476 \\
\hline Employee retirement & $114,931,372$ & $92,695,105$ & $22,236,267$ \\
\hline Workers' compensation & $10,156,751$ & $10,156,751$ & - \\
\hline Other insurance trust & $3,508,317$ & $3,508,317$ & - \\
\hline
\end{tabular}




\begin{tabular}{lccc}
\hline Description & $\begin{array}{c}\text { State and local government } \\
\text { amount }^{\mathrm{a}}\end{array}$ & $\begin{array}{c}\text { State government } \\
\text { amount }\end{array}$ & $\begin{array}{c}\text { Local government } \\
\text { amount }^{\mathrm{a}}\end{array}$ \\
Debt outstanding & & & \\
Cash and security holdings & $1,681,377,464$ & $636,795,733$ & $1,044,581,731$ \\
& $3,650,740,524$ & $2,555,425,220$ & $1,095,315,304$
\end{tabular}

Note: Includes District of Columbia.

${ }^{a}$ Duplicative intergovernmental transactions are excluded. 
Table D2. Index of revenue and tax capacity, various years

\begin{tabular}{|c|c|c|c|c|c|c|c|c|c|c|c|c|c|c|c|c|}
\hline \multirow[b]{2}{*}{ State } & \multicolumn{2}{|c|}{$\begin{array}{c}2002 \text { Rev. } \\
\text { Capacity }\end{array}$} & \multicolumn{2}{|c|}{$\begin{array}{l}2002 \text { Tax } \\
\text { Capacity }\end{array}$} & \multicolumn{2}{|c|}{$\begin{array}{l}1999 \text { Tax } \\
\text { Capacity }\end{array}$} & \multicolumn{2}{|c|}{$\begin{array}{l}1997 \text { Tax } \\
\text { Capacity }\end{array}$} & \multicolumn{2}{|c|}{$\begin{array}{l}1996 \text { Tax } \\
\text { Capacity }\end{array}$} & \multicolumn{2}{|c|}{$\begin{array}{l}1994 \text { Tax } \\
\text { Capacity }\end{array}$} & \multicolumn{2}{|c|}{$\begin{array}{l}1991 \text { Tax } \\
\text { Capacity }\end{array}$} & \multicolumn{2}{|c|}{$\begin{array}{l}1987 \mathrm{Tax} \\
\text { Capacity }\end{array}$} \\
\hline & Index & Rank & Index & Rank & Index & Rank & Index & Rank & Index & Rank & Index & Rank & Index & Rank & Index & Rank \\
\hline Alabama & 82 & 46 & 82 & 46 & 82 & 47 & 81 & 48 & 83 & 48 & 83 & 48 & 81 & 48 & 75 & 49 \\
\hline Alaska & 118 & 5 & 125 & 4 & 109 & 12 & 133 & 1 & 127 & 3 & 135 & 2 & 178 & 1 & 169 & 1 \\
\hline Arizona & 89 & 39 & 91 & 37 & 98 & 23 & 100 & 21 & 94 & 35 & 93 & 34 & 94 & 26 & 100 & 19 \\
\hline Arkansas & 76 & 48 & 76 & 48 & 81 & 48 & 80 & 49 & 81 & 49 & 81 & 49 & 78 & 49 & 75 & 49 \\
\hline California & 109 & 11 & 110 & 11 & 111 & 9 & 116 & 8 & 103 & 17 & 105 & 14 & 115 & 10 & 117 & 9 \\
\hline Colorado & 113 & 8 & 115 & 9 & 105 & 16 & 115 & 9 & 114 & 11 & 110 & 10 & 109 & 12 & 111 & 11 \\
\hline Connecticut & 135 & 1 & 130 & 1 & 127 & 2 & 129 & 3 & 129 & 2 & 132 & 3 & 130 & 4 & 139 & 2 \\
\hline D.G. & NA & NA & NA & NA & 127 & 2 & 123 & 6 & 126 & 5 & 125 & 5 & 123 & 7 & 122 & 7 \\
\hline Delaware & 122 & 3 & 129 & 2 & 123 & 4 & 120 & 7 & 121 & 6 & 119 & 8 & 125 & 6 & 124 & 5 \\
\hline Florida & 102 & 17 & 104 & 14 & 103 & 19 & 98 & 22 & 100 & 20 & 100 & 20 & 103 & 16 & 105 & 15 \\
\hline Georgia & 93 & 29 & 93 & 32 & 98 & 23 & 98 & 22 & 96 & 30 & 95 & 29 & 91 & 32 & 94 & 26 \\
\hline Hawaii & 104 & 15 & 108 & 13 & 116 & 5 & 130 & 2 & 120 & 7 & 125 & 5 & 146 & 2 & 113 & 10 \\
\hline Idaho & 84 & 43 & 86 & 43 & 84 & 45 & 87 & 44 & 90 & 41 & 90 & 40 & 82 & 45 & 77 & 47 \\
\hline Illinois & 104 & 15 & 103 & 16 & 104 & 17 & 103 & 15 & 110 & 12 & 108 & 11 & 102 & 19 & 97 & 22 \\
\hline Indiana & 92 & 33 & 93 & 32 & 94 & 31 & 95 & 27 & 97 & 25 & 96 & 23 & 90 & 36 & 87 & 37 \\
\hline Iowa & 94 & 26 & 96 & 23 & 96 & 27 & 94 & 29 & 97 & 25 & 93 & 34 & 93 & 28 & 84 & 41 \\
\hline Kansas & 91 & 36 & 90 & 38 & 92 & 35 & 94 & 29 & 96 & 30 & 96 & 23 & 93 & 28 & 93 & 27 \\
\hline Kentucky & 91 & 36 & 94 & 30 & 85 & 44 & 86 & 45 & 84 & 46 & 85 & 45 & 83 & 43 & 79 & 44 \\
\hline Louisiana & 83 & 44 & 83 & 44 & 83 & 46 & 89 & 43 & 88 & 43 & 92 & 36 & 89 & 38 & 86 & 40 \\
\hline Maine & 93 & 29 & 95 & 28 & 92 & 35 & 95 & 27 & 89 & 42 & 88 & 43 & 95 & 24 & 97 & 22 \\
\hline Maryland & 107 & 13 & 102 & 18 & 104 & 17 & 106 & 13 & 108 & 14 & 107 & 12 & 106 & 14 & 109 & 13 \\
\hline Massachusetts & 129 & 2 & 126 & 3 & 114 & 6 & 112 & 11 & 116 & 9 & 114 & 9 & 117 & 9 & 127 & 4 \\
\hline Michigan & 97 & 22 & 97 & 22 & 99 & 21 & 96 & 25 & 98 & 24 & 101 & 19 & 94 & 26 & 95 & 25 \\
\hline Minnesota & 109 & 11 & 110 & 11 & 108 & 13 & 103 & 15 & 107 & 15 & 104 & 15 & 101 & 20 & 104 & 16 \\
\hline Mississippi & 72 & 50 & 72 & 50 & 74 & 50 & 71 & 51 & 72 & 51 & 70 & 51 & 68 & 51 & 65 & 51 \\
\hline Missouri & 93 & 29 & 94 & 30 & 93 & 34 & 93 & 33 & 97 & 25 & 95 & 29 & 91 & 32 & 91 & 31 \\
\hline Montana & 90 & 38 & 96 & 23 & 94 & 31 & 92 & 36 & 99 & 21 & 96 & 23 & 91 & 32 & 87 & 37 \\
\hline Nebraska & 95 & 24 & 96 & 23 & 98 & 23 & 98 & 22 & 99 & 21 & 96 & 23 & 95 & 24 & 91 & 31 \\
\hline Nevada & 112 & 9 & 117 & 8 & 129 & 1 & 129 & 3 & 141 & 1 & 142 & 1 & 128 & 5 & 110 & 12 \\
\hline New Hampshire & 118 & 5 & 122 & 6 & 114 & 6 & 110 & 12 & 118 & 8 & 107 & 12 & 110 & 11 & 123 & 6 \\
\hline New Jersey & 121 & 4 & 118 & 7 & 114 & 6 & 114 & 10 & 116 & 9 & 124 & 7 & 119 & 8 & 122 & 7 \\
\hline New Mexico & 85 & 42 & 88 & 41 & 87 & 42 & 90 & 41 & 85 & 44 & 90 & 40 & 87 & 40 & 87 & 37 \\
\hline New York & 112 & 9 & 111 & 10 & 106 & 15 & 106 & 13 & 109 & 13 & 103 & 17 & 103 & 16 & 108 & 14 \\
\hline North Carolina & 92 & 33 & 93 & 32 & 97 & 26 & 93 & 33 & 92 & 36 & 92 & 36 & 93 & 28 & 90 & 34 \\
\hline North Dakota & 94 & 26 & 99 & 21 & 96 & 27 & 96 & 25 & 97 & 25 & 94 & 33 & 91 & 32 & 90 & 34 \\
\hline Ohio & 94 & 26 & 93 & 32 & 94 & 31 & 94 & 29 & 96 & 30 & 97 & 22 & 93 & 28 & 91 & 31 \\
\hline Oklahoma & 82 & 46 & 82 & 46 & 79 & 49 & 83 & 47 & 84 & 46 & 86 & 44 & 87 & 40 & 93 & 27 \\
\hline Oregon & 99 & 21 & 100 & 19 & 108 & 13 & 103 & 15 & 103 & 17 & 99 & 21 & 100 & 21 & 92 & 29 \\
\hline Pennsylvania & 95 & 24 & 92 & 36 & 92 & 35 & 92 & 36 & 95 & 33 & 96 & 23 & 96 & 23 & 92 & 29 \\
\hline Rhode Island & 101 & 19 & 95 & 28 & 91 & 39 & 92 & 36 & 91 & 39 & 91 & 38 & 89 & 38 & 96 & 24 \\
\hline South Carolina & 83 & 44 & 83 & 44 & 86 & 43 & 84 & 46 & 85 & 44 & 85 & 45 & 83 & 43 & 80 & 43 \\
\hline South Dakota & 93 & 29 & 96 & 23 & 96 & 27 & 94 & 29 & 95 & 33 & 91 & 38 & 86 & 42 & 78 & 46 \\
\hline Tennessee & 89 & 39 & 89 & 40 & 92 & 35 & 90 & 41 & 92 & 36 & 90 & 40 & 82 & 45 & 84 & 41 \\
\hline Texas & 92 & 33 & 90 & 38 & 90 & 40 & 91 & 40 & 91 & 39 & 95 & 29 & 97 & 22 & 99 & 20 \\
\hline Utah & 86 & 41 & 88 & 41 & 90 & 40 & 92 & 36 & 92 & 36 & 85 & 45 & 82 & 45 & 79 & 44 \\
\hline Vermont & 100 & 20 & 103 & 16 & 99 & 21 & 101 & 18 & 99 & 21 & 95 & 29 & 105 & 15 & 103 & 17 \\
\hline Virginia & 102 & 17 & 100 & 19 & 102 & 20 & 101 & 18 & 101 & 19 & 104 & 15 & 103 & 16 & 102 & 18 \\
\hline Washington & 105 & 14 & 104 & 14 & 110 & 11 & 101 & 18 & 104 & 16 & 102 & 18 & 108 & 13 & 99 & 20 \\
\hline West Virginia & 76 & 48 & 74 & 49 & 72 & 51 & 77 & 50 & 78 & 50 & 81 & 49 & 77 & 50 & 77 & 47 \\
\hline Wisconsin & 96 & 23 & 96 & 23 & 96 & 27 & 93 & 33 & 97 & 25 & 96 & 23 & 90 & 36 & 88 & 36 \\
\hline Wyoming & 115 & 7 & 123 & 5 & 111 & 9 & 125 & 5 & 127 & 3 & 128 & 4 & 134 & 3 & 137 & 3 \\
\hline
\end{tabular}


Table D3. Index of revenue and tax effort, various years

\begin{tabular}{|c|c|c|c|c|c|c|c|c|c|c|c|c|}
\hline \multirow[b]{2}{*}{ State } & \multicolumn{2}{|c|}{2002 Revenue Effort } & \multicolumn{2}{|c|}{2002 Tax Effort } & \multicolumn{2}{|c|}{1999 Tax Effort } & \multicolumn{2}{|c|}{1997 Tax Effort } & \multicolumn{2}{|c|}{1996 Tax Effort } & \multicolumn{2}{|c|}{1994 Tax Effort } \\
\hline & Index & Rank & Index & Rank & Index & Rank & Index & Rank & Index & Rank & Index & Rank \\
\hline Alabama & 103 & 18 & 85 & 41 & 82 & 45 & 82 & 46 & 83 & 44 & 80 & 49 \\
\hline Alaska & 155 & 1 & 82 & 43 & 87 & 41 & 110 & 9 & 116 & 5 & 100 & 18 \\
\hline Arizona & 89 & 43 & 93 & 33 & 87 & 41 & 84 & 44 & 93 & 29 & 97 & 21 \\
\hline Arkansas & 101 & 22 & 99 & 19 & 91 & 37 & 95 & 30 & 92 & 30 & 86 & 40 \\
\hline California & 102 & 20 & 99 & 19 & 96 & 24 & 88 & 41 & 101 & 16 & 96 & 23 \\
\hline Colorado & 93 & 40 & 86 & 40 & 95 & 26 & 83 & 45 & 82 & 45 & 85 & 42 \\
\hline Connecticut & 87 & 46 & 107 & 9 & 119 & 3 & 121 & 4 & 115 & 6 & 109 & 6 \\
\hline D.C. & NA & NA & NA & NA & 151 & 1 & 153 & 1 & 141 & 1 & 148 & 2 \\
\hline Delaware & 105 & 12 & 82 & 43 & 89 & 40 & 90 & 36 & 90 & 33 & 87 & 39 \\
\hline Florida & 93 & 40 & 83 & 42 & 86 & 43 & 91 & 33 & 90 & 33 & 91 & 33 \\
\hline Georgia & 95 & 35 & 96 & 25 & 94 & 29 & 91 & 33 & 95 & 27 & 93 & 30 \\
\hline Hawaii & 99 & 27 & 101 & 16 & 95 & 26 & 93 & 31 & 104 & 10 & 107 & 10 \\
\hline Idaho & 101 & 22 & 91 & 35 & 97 & 22 & 97 & 24 & 92 & 30 & 91 & 33 \\
\hline Illinois & 94 & 37 & 102 & 14 & 101 & 16 & 102 & 15 & 97 & 26 & 96 & 23 \\
\hline Indiana & 99 & 27 & 94 & 29 & 93 & 32 & 99 & 23 & 88 & 40 & 92 & 32 \\
\hline Iowa & 104 & 14 & 95 & 28 & 93 & 32 & 100 & 20 & 98 & 25 & 103 & 14 \\
\hline Kansas & 102 & 20 & 103 & 13 & 99 & 17 & 103 & 14 & 99 & 21 & 101 & 16 \\
\hline Kentucky & 92 & 42 & 89 & 38 & 97 & 22 & 97 & 24 & 99 & 21 & 95 & 26 \\
\hline Louisiana & 114 & 4 & 104 & 12 & 98 & 20 & 89 & 39 & 86 & 42 & 78 & 50 \\
\hline Maine & 112 & 6 & 118 & 2 & 118 & 5 & 112 & 7 & 113 & 8 & 111 & 5 \\
\hline Maryland & 98 & 29 & 114 & 4 & 103 & 12 & 100 & 20 & 100 & 17 & 103 & 14 \\
\hline Massachusetts & 86 & 47 & 94 & 29 & 106 & 11 & 109 & 10 & 104 & 10 & 104 & 13 \\
\hline Michigan & 101 & 22 & 100 & 18 & 103 & 12 & 106 & 11 & 100 & 17 & 105 & 11 \\
\hline Minnesota & 108 & 8 & 107 & 9 & 113 & 7 & 122 & 3 & 113 & 8 & 109 & 6 \\
\hline Mississippi & 112 & 6 & 101 & 16 & 99 & 17 & 102 & 15 & 102 & 13 & 98 & 20 \\
\hline Missouri & 89 & 43 & 90 & 37 & 92 & 34 & 92 & 32 & 87 & 41 & 82 & 46 \\
\hline Montana & 94 & 37 & 78 & 49 & 82 & 45 & 87 & 42 & 79 & 46 & 85 & 42 \\
\hline Nebraska & 104 & 14 & 102 & 14 & 94 & 29 & 101 & 19 & 99 & 21 & 100 & 18 \\
\hline Nevada & 89 & 43 & 82 & 43 & 76 & 50 & 73 & 51 & 73 & 51 & 69 & 51 \\
\hline New Hampshire & 76 & 50 & 75 & 50 & 76 & 50 & 79 & 48 & 74 & 49 & 85 & 42 \\
\hline New Jersey & 98 & 29 & 110 & 7 & 113 & 7 & 112 & 7 & 114 & 7 & 108 & 9 \\
\hline New Mexico & 107 & 11 & 96 & 25 & 99 & 17 & 97 & 24 & 102 & 13 & 97 & 21 \\
\hline New York & 122 & 2 & 134 & 1 & 143 & 2 & 144 & 2 & 141 & 1 & 155 & 1 \\
\hline North Carolina & 96 & 33 & 93 & 33 & 92 & 34 & 96 & 28 & 94 & 28 & 96 & 23 \\
\hline North Dakota & 103 & 18 & 88 & 39 & 92 & 34 & 96 & 28 & 89 & 36 & 89 & 35 \\
\hline Ohio & 105 & 12 & 109 & 8 & 103 & 12 & 102 & 15 & 100 & 17 & 95 & 26 \\
\hline Oklahoma & 104 & 14 & 98 & 23 & 98 & 20 & 97 & 24 & 92 & 30 & 89 & 35 \\
\hline Oregon & 95 & 35 & 82 & 43 & 80 & 47 & 85 & 43 & 85 & 43 & 95 & 26 \\
\hline Pennsylvania & 104 & 14 & 105 & 11 & 107 & 10 & 104 & 13 & 102 & 13 & 101 & 16 \\
\hline Rhode Island & 98 & 29 & 115 & 3 & 119 & 3 & 118 & 6 & 117 & 3 & 114 & 4 \\
\hline South Carolina & 101 & 22 & 91 & 35 & 90 & 39 & 90 & 36 & 89 & 36 & 88 & 38 \\
\hline South Dakota & 85 & 48 & 81 & 47 & 79 & 48 & 79 & 48 & 79 & 46 & 83 & 45 \\
\hline Tennessee & 83 & 49 & 81 & 47 & 78 & 49 & 81 & 47 & 79 & 46 & 81 & 48 \\
\hline Texas & 94 & 37 & 96 & 25 & 91 & 37 & 91 & 33 & 90 & 33 & 89 & 35 \\
\hline Utah & 108 & 8 & 94 & 29 & 95 & 26 & 90 & 36 & 89 & 36 & 93 & 30 \\
\hline Vermont & 97 & 32 & 99 & 19 & 102 & 15 & 102 & 15 & 100 & 17 & 109 & 6 \\
\hline Virginia & 96 & 33 & 97 & 24 & 94 & 29 & 89 & 39 & 89 & 36 & 86 & 40 \\
\hline Washington & 101 & 22 & 99 & 19 & 96 & 24 & 105 & 12 & 104 & 10 & 105 & 11 \\
\hline West Virginia & 113 & 5 & 111 & 6 & 110 & 9 & 100 & 20 & 99 & 21 & 95 & 26 \\
\hline Wisconsin & 108 & 8 & 113 & 5 & 115 & 6 & 121 & 4 & 117 & 3 & 117 & 3 \\
\hline Wyoming & 115 & 3 & 94 & 29 & 86 & 43 & 77 & 50 & 74 & 49 & 82 & 46 \\
\hline
\end{tabular}


Table D4. Index of expenditure need, various years

\begin{tabular}{|c|c|c|c|c|c|c|c|c|c|c|}
\hline \multirow[b]{2}{*}{ State } & \multicolumn{2}{|c|}{$\begin{array}{l}2002 \text { Expenditure } \\
\text { Need }\end{array}$} & \multicolumn{2}{|c|}{$\begin{array}{l}1999 \text { Expenditure } \\
\text { Need }\end{array}$} & \multicolumn{2}{|c|}{$\begin{array}{c}1997 \text { Expenditure } \\
\text { Need }\end{array}$} & \multicolumn{2}{|c|}{$\begin{array}{l}1996 \text { Expenditure } \\
\text { Need }\end{array}$} & \multicolumn{2}{|c|}{$\begin{array}{l}1994 \text { Expenditure } \\
\text { Need }\end{array}$} \\
\hline & Index & Rank & Index & Rank & Index & Rank & Index & Rank & Index & Rank \\
\hline Alabama & 108 & 4 & 103 & 11 & 102 & 13 & 104 & 8 & 102 & 12 \\
\hline Alaska & 100 & 21 & 110 & 3 & 106 & 7 & 102 & 12 & 104 & 8 \\
\hline Arizona & 102 & 15 & 103 & 11 & 106 & 7 & 105 & 7 & 100 & 16 \\
\hline Arkansas & 109 & 3 & 100 & 18 & 106 & 7 & 100 & 20 & 97 & 23 \\
\hline California & 103 & 13 & 107 & 4 & 109 & 3 & 110 & 3 & 110 & 3 \\
\hline Colorado & 93 & 38 & 97 & 32 & 90 & 44 & 90 & 42 & 88 & 43 \\
\hline Connecticut & 96 & 30 & 98 & 26 & 101 & 17 & 102 & 12 & 101 & 14 \\
\hline D.C. & NA & NA & 118 & 1 & 121 & 1 & 126 & 1 & 116 & 1 \\
\hline Delaware & 93 & 38 & 96 & 37 & 89 & 46 & 89 & 45 & 88 & 43 \\
\hline Florida & 94 & 36 & 92 & 47 & 95 & 32 & 96 & 25 & 94 & 32 \\
\hline Georgia & 105 & 7 & 105 & 6 & 106 & 7 & 104 & 8 & 104 & 8 \\
\hline Hawaii & 87 & 50 & 90 & 50 & 92 & 41 & 90 & 42 & 85 & 49 \\
\hline Idaho & 98 & 22 & 102 & 13 & 100 & 19 & 100 & 20 & 97 & 23 \\
\hline Illinois & 102 & 15 & 99 & 22 & 100 & 19 & 101 & 15 & 100 & 16 \\
\hline Indiana & 98 & 22 & 96 & 37 & 93 & 38 & 92 & 39 & 99 & 19 \\
\hline Iowa & 91 & 46 & 90 & 50 & 89 & 46 & 89 & 45 & 88 & 43 \\
\hline Kansas & 97 & 25 & 98 & 26 & 95 & 32 & 95 & 29 & 99 & 19 \\
\hline Kentucky & 102 & 15 & 99 & 22 & 103 & 12 & 101 & 15 & 104 & 8 \\
\hline Louisiana & 110 & 2 & 106 & 5 & 107 & 4 & 109 & 5 & 115 & 2 \\
\hline Maine & 93 & 38 & 91 & 48 & 89 & 46 & 88 & 49 & 85 & 49 \\
\hline Maryland & 95 & 34 & 97 & 32 & 94 & 35 & 95 & 29 & 94 & 32 \\
\hline Massachusetts & 95 & 34 & 96 & 37 & 94 & 35 & 93 & 37 & 90 & 41 \\
\hline Michigan & 104 & 9 & 104 & 8 & 100 & 19 & 101 & 15 & 104 & 8 \\
\hline Minnesota & 92 & 45 & 98 & 26 & 95 & 32 & 94 & 35 & 96 & 27 \\
\hline Mississippi & 113 & 1 & 104 & 8 & 107 & 4 & 110 & 3 & 105 & 7 \\
\hline Missouri & 97 & 25 & 96 & 37 & 96 & 29 & 92 & 39 & 100 & 16 \\
\hline Montana & 97 & 25 & 101 & 16 & 100 & 19 & 98 & 23 & 91 & 39 \\
\hline Nebraska & 94 & 36 & 96 & 37 & 89 & 46 & 88 & 49 & 86 & 47 \\
\hline Nevada & 91 & 46 & 100 & 18 & 94 & 35 & 94 & 35 & 93 & 35 \\
\hline New Hampshire & 88 & 49 & 93 & 46 & 87 & 51 & 84 & 51 & 86 & 47 \\
\hline New Jersey & 97 & 25 & 97 & 32 & 97 & 26 & 95 & 29 & 95 & 30 \\
\hline New Mexico & 108 & 4 & 112 & 2 & 112 & 2 & 115 & 2 & 107 & 5 \\
\hline New York & 101 & 19 & 101 & 16 & 104 & 11 & 104 & 8 & 107 & 5 \\
\hline North Carolina & 102 & 15 & 100 & 18 & 96 & 29 & 95 & 29 & 97 & 23 \\
\hline North Dakota & 104 & 9 & 102 & 13 & 98 & 23 & 96 & 25 & 93 & 35 \\
\hline Ohio & 97 & 25 & 98 & 26 & 97 & 26 & 97 & 24 & 99 & 19 \\
\hline Oklahoma & 101 & 19 & 99 & 22 & 102 & 13 & 104 & 8 & 102 & 12 \\
\hline Oregon & 93 & 38 & 100 & 18 & 92 & 41 & 91 & 41 & 91 & 39 \\
\hline Pennsylvania & 93 & 38 & 94 & 43 & 93 & 38 & 93 & 37 & 93 & 35 \\
\hline Rhode Island & 93 & 38 & 94 & 43 & 91 & 43 & 89 & 45 & 88 & 43 \\
\hline South Carolina & 105 & 7 & 98 & 26 & 97 & 26 & 101 & 15 & 96 & 27 \\
\hline South Dakota & 96 & 30 & 95 & 42 & 98 & 23 & 96 & 25 & 97 & 23 \\
\hline Tennessee & 104 & 9 & 98 & 26 & 102 & 13 & 102 & 12 & 99 & 19 \\
\hline Texas & 107 & 6 & 105 & 6 & 107 & 4 & 108 & 6 & 110 & 3 \\
\hline Utah & 103 & 13 & 104 & 8 & 96 & 29 & 95 & 29 & 95 & 30 \\
\hline Vermont & 91 & 46 & 91 & 48 & 89 & 46 & 90 & 42 & 83 & 51 \\
\hline Virginia & 96 & 30 & 97 & 32 & 98 & 23 & 96 & 25 & 94 & 32 \\
\hline Washington & 96 & 30 & 97 & 32 & 93 & 38 & 95 & 29 & 93 & 35 \\
\hline West Virginia & 104 & 9 & 99 & 22 & 101 & 17 & 100 & 20 & 101 & 14 \\
\hline Wisconsin & 93 & 38 & 94 & 43 & 90 & 44 & 89 & 45 & 89 & 42 \\
\hline Wyoming & 98 & 22 & 102 & 13 & 102 & 13 & 101 & 15 & 96 & 27 \\
\hline
\end{tabular}


Table D5. Index of fiscal capacity, various years

\begin{tabular}{|c|c|c|c|c|c|c|c|c|c|c|c|c|}
\hline \multirow[b]{2}{*}{ State } & \multicolumn{2}{|c|}{$\begin{array}{l}\text { 2002 Fiscal } \\
\text { Capacity }\end{array}$} & \multicolumn{2}{|c|}{$\begin{array}{c}1999 \text { Fiscal } \\
\text { Capacity }\end{array}$} & \multicolumn{2}{|c|}{$\begin{array}{l}1997 \text { Fiscal } \\
\text { Capacity }\end{array}$} & \multicolumn{2}{|c|}{$\begin{array}{c}1996 \text { Fiscal } \\
\text { Capacity }\end{array}$} & \multicolumn{2}{|c|}{$\begin{array}{c}1994 \text { Fiscal } \\
\text { Capacity }\end{array}$} & \multicolumn{2}{|c|}{$\begin{array}{c}1987 \text { Fiscal } \\
\text { Capacity }\end{array}$} \\
\hline & Index & Rank & Index & Rank & Index & Rank & Index & Rank & Index & Rank & Index & Rank \\
\hline Alabama & 76 & 46 & 80 & 46 & 79 & 48 & 79 & 48 & 81 & 48 & 69 & 50 \\
\hline Alaska & 118 & 9 & 99 & 26 & 126 & 6 & 124 & 9 & 130 & 7 & 139 & 6 \\
\hline Arizona & 87 & 38 & 96 & 31 & 95 & 37 & 90 & 39 & 93 & 37 & 77 & 43 \\
\hline Arkansas & 70 & 49 & 81 & 45 & 76 & 49 & 81 & 45 & 84 & 44 & 70 & 49 \\
\hline California & 106 & 18 & 103 & 21 & 106 & 18 & 94 & 37 & 95 & 33 & 116 & 11 \\
\hline Colorado & 122 & 7 & 107 & 15 & 127 & 5 & 126 & 5 & 125 & 9 & 113 & 13 \\
\hline Connecticut & 141 & 1 & 129 & 2 & 128 & 4 & 126 & 5 & 131 & 5 & 152 & 1 \\
\hline D.C. & NA & NA & 108 & 12 & 101 & 25 & 100 & 30 & 108 & 17 & 119 & 10 \\
\hline Delaware & 131 & 4 & 129 & 2 & 134 & 3 & 135 & 3 & 135 & 3 & 128 & 8 \\
\hline Florida & 109 & 15 & 112 & 9 & 103 & 20 & 104 & 24 & 106 & 21 & 113 & 13 \\
\hline Georgia & 89 & 36 & 94 & 35 & 92 & 39 & 92 & 38 & 91 & 39 & 87 & 35 \\
\hline Hawaii & 120 & 8 & 130 & 1 & 141 & 1 & 134 & 4 & 147 & 2 & 126 & 9 \\
\hline Idaho & 86 & 39 & 83 & 44 & 87 & 40 & 90 & 39 & 93 & 37 & 77 & 43 \\
\hline Illinois & 102 & 23 & 105 & 18 & 103 & 20 & 109 & 16 & 108 & 17 & 95 & 22 \\
\hline Indiana & 94 & 30 & 98 & 27 & 101 & 25 & 105 & 20 & 97 & 29 & 88 & 33 \\
\hline Iowa & 103 & 21 & 106 & 17 & 106 & 18 & 108 & 19 & 106 & 21 & 87 & 35 \\
\hline Kansas & 94 & 30 & 94 & 35 & 99 & 28 & 101 & 27 & 97 & 29 & 95 & 22 \\
\hline Kentucky & 89 & 36 & 85 & 43 & 83 & 44 & 83 & 44 & 82 & 47 & 73 & 48 \\
\hline Louisiana & 75 & 47 & 78 & 48 & 83 & 44 & 81 & 45 & 80 & 49 & 78 & 40 \\
\hline Maine & 100 & 26 & 101 & 24 & 107 & 17 & 100 & 30 & 104 & 24 & 109 & 17 \\
\hline Maryland & 113 & 12 & 107 & 15 & 113 & 11 & 113 & 11 & 114 & 11 & 112 & 15 \\
\hline Massachusetts & 136 & 2 & 119 & 6 & 120 & 9 & 125 & 8 & 127 & 8 & 145 & 4 \\
\hline Michigan & 93 & 32 & 95 & 34 & 96 & 33 & 97 & 34 & 97 & 29 & 88 & 33 \\
\hline Minnesota & 118 & 9 & 109 & 10 & 108 & 16 & 113 & 11 & 108 & 17 & 106 & 18 \\
\hline Mississippi & 64 & 50 & 71 & 51 & 67 & 51 & 65 & 51 & 67 & 51 & 57 & 51 \\
\hline Missouri & 96 & 29 & 97 & 29 & 97 & 31 & 105 & 20 & 95 & 33 & 91 & 28 \\
\hline Montana & 93 & 32 & 93 & 39 & 93 & 38 & 101 & 27 & 105 & 23 & 85 & 38 \\
\hline Nebraska & 101 & 25 & 103 & 21 & 109 & 14 & 112 & 14 & 112 & 13 & 94 & 25 \\
\hline Nevada & 123 & 6 & 129 & 2 & 137 & 2 & 150 & 1 & 153 & 1 & 147 & 3 \\
\hline New Hampshire & 134 & 3 & 122 & 5 & 126 & 6 & 141 & 2 & 124 & 10 & 144 & 5 \\
\hline New Jersey & 125 & 5 & 118 & 7 & 118 & 10 & 122 & 10 & 131 & 5 & 152 & 1 \\
\hline New Mexico & 79 & 44 & 78 & 48 & 80 & 47 & 74 & 50 & 84 & 44 & 78 & 40 \\
\hline New York & 111 & 13 & 104 & 20 & 102 & 24 & 105 & 20 & 96 & 32 & 91 & 28 \\
\hline North Carolina & 90 & 34 & 97 & 29 & 96 & 33 & 97 & 34 & 95 & 33 & 91 & 28 \\
\hline North Dakota & 90 & 34 & 94 & 35 & 99 & 28 & 101 & 27 & 101 & 27 & 86 & 37 \\
\hline Ohio & 97 & 27 & 96 & 31 & 97 & 31 & 99 & 33 & 98 & 28 & 95 & 22 \\
\hline Oklahoma & 81 & 43 & 80 & 46 & 82 & 46 & 80 & 47 & 84 & 44 & 90 & 31 \\
\hline Oregon & 106 & 18 & 108 & 12 & 113 & 11 & 113 & 11 & 109 & 16 & 94 & 25 \\
\hline Pennsylvania & 102 & 23 & 98 & 27 & 99 & 28 & 102 & 25 & 103 & 25 & 102 & 21 \\
\hline Rhode Island & 109 & 15 & 96 & 31 & 101 & 25 & 102 & 25 & 103 & 25 & 112 & 15 \\
\hline South Carolina & 79 & 44 & 88 & 40 & 87 & 40 & 85 & 42 & 89 & 41 & 76 & 45 \\
\hline South Dakota & 97 & 27 & 101 & 24 & 96 & 33 & 100 & 30 & 94 & 36 & 75 & 46 \\
\hline Tennessee & 86 & 39 & 94 & 35 & 87 & 40 & 90 & 39 & 91 & 39 & 81 & 39 \\
\hline Texas & 86 & 39 & 86 & 42 & 85 & 43 & 85 & 42 & 86 & 43 & 90 & 31 \\
\hline Utah & 83 & 42 & 87 & 41 & 96 & 33 & 97 & 34 & 89 & 41 & 75 & 46 \\
\hline Vermont & 110 & 14 & 109 & 10 & 113 & 11 & 111 & 15 & 114 & 11 & 115 & 12 \\
\hline Virginia & 106 & 18 & 105 & 18 & 103 & 20 & 105 & 20 & 111 & 14 & 104 & 19 \\
\hline Washington & 109 & 15 & 113 & 8 & 109 & 14 & 109 & 16 & 110 & 15 & 104 & 19 \\
\hline West Virginia & 73 & 48 & 72 & 50 & 76 & 49 & 78 & 49 & 80 & 49 & 78 & 40 \\
\hline Wisconsin & 103 & 21 & 102 & 23 & 103 & 20 & 109 & 16 & 108 & 17 & 93 & 27 \\
\hline Wyoming & 117 & 11 & 108 & 12 & 122 & 8 & 126 & 5 & 133 & 4 & 134 & 7 \\
\hline
\end{tabular}


Table D6. Summary data, representative revenue system, FY2002

\begin{tabular}{|c|c|c|c|c|c|c|c|c|c|}
\hline State & $\begin{array}{c}2002 \\
\text { population }\end{array}$ & $\begin{array}{c}2002 \text { revenue } \\
\text { capacity (\$millions) }\end{array}$ & $\begin{array}{c}\text { Per capita } \\
\text { revenue capacity }\end{array}$ & $\begin{array}{c}\text { Revenue } \\
\text { capacity index }\end{array}$ & Rank & $\begin{array}{c}2002 \\
\text { revenue } \\
\text { (\$millions) }\end{array}$ & $\begin{array}{l}\text { Per capita } \\
\text { revenue }\end{array}$ & $\begin{array}{l}\text { Revenue } \\
\text { effort index }\end{array}$ & Rank \\
\hline United States & $287,376,577$ & $\$ 1,338,934$ & $\$ 4,659$ & 100 & & $\$ 1,338,934$ & $\$ 4,659$ & 100 & \\
\hline Alabama & $4,481,078$ & 17,118 & 3,820 & 82 & 46 & 17,613 & 3,931 & 103 & 18 \\
\hline Alaska & 640,841 & 3,522 & 5,496 & 118 & 5 & 5,471 & 8,537 & 155 & 1 \\
\hline Arizona & $5,439,091$ & 22,555 & 4,147 & 89 & 39 & 20,027 & 3,682 & 89 & 43 \\
\hline Arkansas & $2,707,509$ & 9,632 & 3,557 & 76 & 48 & 9,694 & 3,580 & 101 & 22 \\
\hline California & $34,988,261$ & 177,012 & 5,059 & 109 & 11 & 181,031 & 5,174 & 102 & 20 \\
\hline Colorado & $4,498,077$ & 23,758 & 5,282 & 113 & 8 & 22,002 & 4,891 & 93 & 40 \\
\hline Connecticut & $3,459,006$ & 21,696 & 6,272 & 135 & 1 & 18,839 & 5,446 & 87 & 46 \\
\hline Delaware & 806,105 & 4,577 & 5,678 & 122 & 3 & 4,822 & 5,982 & 105 & 12 \\
\hline Florida & $16,681,144$ & 78,902 & 4,730 & 102 & 17 & 73,366 & 4,398 & 93 & 40 \\
\hline Georgia & $8,539,735$ & 37,118 & 4,346 & 93 & 29 & 35,237 & 4,126 & 95 & 35 \\
\hline Hawaii & $1,234,514$ & 5,984 & 4,848 & 104 & 15 & 5,929 & 4,802 & 99 & 27 \\
\hline Idaho & $1,343,194$ & 5,259 & 3,915 & 84 & 43 & 5,318 & 3,959 & 101 & 22 \\
\hline Illinois & $12,585,204$ & 60,956 & 4,843 & 104 & 15 & 57,131 & 4,540 & 94 & 37 \\
\hline Indiana & $6,158,327$ & 26,529 & 4,308 & 92 & 33 & 26,308 & 4,272 & 99 & 27 \\
\hline Iowa & $2,934,776$ & 12,819 & 4,368 & 94 & 26 & 13,372 & 4,556 & 104 & 14 \\
\hline Kansas & $2,712,896$ & 11,458 & 4,224 & 91 & 36 & 11,635 & 4,289 & 102 & 20 \\
\hline Kentucky & $4,089,985$ & 17,255 & 4,219 & 91 & 36 & 15,944 & 3,898 & 92 & 42 \\
\hline Louisiana & $4,477,042$ & 17,218 & 3,846 & 83 & 44 & 19,692 & 4,398 & 114 & 4 \\
\hline Maine & $1,297,750$ & 5,634 & 4,342 & 93 & 29 & 6,287 & 4,844 & 112 & 6 \\
\hline Maryland & $5,441,531$ & 27,243 & 5,007 & 107 & 13 & 26,710 & 4,908 & 98 & 29 \\
\hline Massachusetts & $6,412,554$ & 38,437 & 5,994 & 129 & 2 & 33,208 & 5,179 & 86 & 47 \\
\hline Michigan & $10,042,495$ & 45,464 & 4,527 & 97 & 22 & 45,890 & 4,570 & 101 & 22 \\
\hline Minnesota & $5,025,081$ & 25,412 & 5,057 & 109 & 11 & 27,369 & 5,446 & 108 & 8 \\
\hline Mississippi & $2,867,635$ & 9,612 & 3,352 & 72 & 50 & 10,804 & 3,768 & 112 & 6 \\
\hline Missouri & $5,679,770$ & 24,684 & 4,346 & 93 & 29 & 21,859 & 3,849 & 89 & 43 \\
\hline Montana & 910,670 & 3,832 & 4,208 & 90 & 38 & 3,600 & 3,954 & 94 & 37 \\
\hline Nebraska & $1,726,437$ & 7,649 & 4,430 & 95 & 24 & 7,917 & 4,586 & 104 & 14 \\
\hline Nevada & $2,168,304$ & 11,313 & 5,217 & 112 & 9 & 10,016 & 4,619 & 89 & 43 \\
\hline New Hampshire & $1,275,607$ & 6,993 & 5,482 & 118 & 5 & 5,283 & 4,142 & 76 & 50 \\
\hline New Jersey & $8,577,250$ & 48,467 & 5,651 & 121 & 4 & 47,641 & 5,554 & 98 & 29 \\
\hline New Mexico & $1,855,143$ & 7,321 & 3,946 & 85 & 42 & 7,814 & 4,212 & 107 & 11 \\
\hline New York & $19,151,066$ & 100,351 & 5,240 & 112 & 9 & 122,107 & 6,376 & 122 & 2 \\
\hline North Carolina & $8,311,899$ & 35,588 & 4,282 & 92 & 33 & 34,172 & 4,111 & 96 & 33 \\
\hline North Dakota & 633,799 & 2,790 & 4,402 & 94 & 26 & 2,878 & 4,541 & 103 & 18 \\
\hline Ohio & $11,410,396$ & 49,977 & 4,380 & 94 & 26 & 52,306 & 4,584 & 105 & 12 \\
\hline Oklahoma & $3,488,201$ & 13,377 & 3,835 & 82 & 46 & 13,871 & 3,977 & 104 & 14 \\
\hline Oregon & $3,523,281$ & 16,311 & 4,629 & 99 & 21 & 15,505 & 4,401 & 95 & 35 \\
\hline Pennsylvania & $12,328,459$ & 54,465 & 4,418 & 95 & 24 & 56,780 & 4,606 & 104 & 14 \\
\hline Rhode Island & $1,068,897$ & 5,024 & 4,701 & 101 & 19 & 4,946 & 4,627 & 98 & 29 \\
\hline South Carolina & $4,105,848$ & 15,855 & 3,861 & 83 & 44 & 16,045 & 3,908 & 101 & 22 \\
\hline South Dakota & 760,452 & 3,307 & 4,349 & 93 & 29 & 2,805 & 3,689 & 85 & 48 \\
\hline
\end{tabular}




\begin{tabular}{|c|c|c|c|c|c|c|c|c|c|}
\hline State & $\begin{array}{c}2002 \\
\text { population }\end{array}$ & $\begin{array}{c}2002 \text { revenue } \\
\text { capacity (\$millions) }\end{array}$ & $\begin{array}{c}\text { Per capita } \\
\text { revenue capacity }\end{array}$ & $\begin{array}{c}\text { Revenue } \\
\text { capacity index }\end{array}$ & Rank & $\begin{array}{c}2002 \\
\text { revenue } \\
\text { (\$millions) }\end{array}$ & $\begin{array}{l}\text { Per capita } \\
\text { revenue }\end{array}$ & $\begin{array}{l}\text { Revenue } \\
\text { effort index }\end{array}$ & Rank \\
\hline Tennessee & $5,792,297$ & 23,976 & 4,139 & 89 & 39 & 19,988 & 3,451 & 83 & 49 \\
\hline Texas & $21,723,220$ & 92,786 & 4,271 & 92 & 33 & 87,273 & 4,017 & 94 & 37 \\
\hline Utah & $2,319,743$ & 9,245 & 3,985 & 86 & 41 & 10,016 & 4,318 & 108 & 8 \\
\hline Vermont & 616,500 & 2,874 & 4,662 & 100 & 20 & 2,792 & 4,528 & 97 & 32 \\
\hline Virginia & $7,273,572$ & 34,550 & 4,750 & 102 & 17 & 33,138 & 4,556 & 96 & 33 \\
\hline Washington & $6,067,146$ & 29,554 & 4,871 & 105 & 14 & 29,845 & 4,919 & 101 & 22 \\
\hline West Virginia & $1,805,230$ & 6,412 & 3,552 & 76 & 48 & 7,247 & 4,015 & 113 & 5 \\
\hline Wisconsin & $5,440,367$ & 24,382 & 4,482 & 96 & 23 & 26,317 & 4,837 & 108 & 8 \\
\hline Wyoming & 499,192 & 2,681 & 5,370 & 115 & 7 & 3,075 & 6,160 & 115 & 3 \\
\hline
\end{tabular}


Table D7. Summary data, revenue capacity (\$millions, except population), FY2002, part I

\begin{tabular}{|c|c|c|c|c|c|c|c|c|c|c|c|}
\hline State & $\begin{array}{c}2002 \\
\text { population }\end{array}$ & $\begin{array}{c}\text { General sales } \\
\text { tax capacity }\end{array}$ & $\begin{array}{l}\text { Motor } \\
\text { fuels tax } \\
\text { capacity }\end{array}$ & $\begin{array}{c}\text { Public } \\
\text { utilities tax } \\
\text { capacity }\end{array}$ & $\begin{array}{c}\text { Insurance } \\
\text { tax } \\
\text { capacity }\end{array}$ & $\begin{array}{c}\text { Tobacco } \\
\text { tax } \\
\text { capacity }\end{array}$ & $\begin{array}{c}\text { Alcohol } \\
\text { (beer, wine, } \\
\text { and spirits) } \\
\text { tax capacity }\end{array}$ & $\begin{array}{l}\text { Amusement } \\
\text { tax capacity }\end{array}$ & $\begin{array}{c}\text { Pari- } \\
\text { mutuels } \\
\text { tax } \\
\text { capacity }\end{array}$ & $\begin{array}{c}\text { Motor } \\
\text { vehicle } \\
\text { license tax } \\
\text { capacity }\end{array}$ & $\begin{array}{c}\text { Motor } \\
\text { vehicle } \\
\text { operator } \\
\text { license tax } \\
\text { capacity }\end{array}$ \\
\hline United States & $287,376,577$ & 222,428 & 33,009 & 20,097 & 11,158 & 9,076 & 12,046 & 4,079 & 308 & 16,925 & 1,419 \\
\hline Alabama & $4,481,078$ & 2,963 & 631 & 323 & 124 & 168 & 162 & 24 & 4 & 323 & 26 \\
\hline Alaska & 640,841 & 555 & 71 & 53 & 24 & 18 & 32 & 9 & 0 & 45 & 3 \\
\hline Arizona & $5,439,091$ & 4,114 & 630 & 347 & 259 & 123 & 251 & 87 & 5 & 291 & 26 \\
\hline Arkansas & $2,707,509$ & 1,691 & 371 & 186 & 71 & 104 & 94 & 13 & 5 & 138 & 14 \\
\hline California & $34,988,261$ & 27,502 & 3,542 & 2,323 & 1,223 & 549 & 1,423 & 638 & 41 & 2,150 & 161 \\
\hline Colorado & $4,498,077$ & 3,921 & 505 & 315 & 193 & 130 & 241 & 93 & 3 & 250 & 24 \\
\hline Connecticut & $3,459,006$ & 3,115 & 341 & 257 & 247 & 101 & 152 & 49 & 6 & 215 & 19 \\
\hline Delaware & 806,105 & 793 & 92 & 61 & 139 & 50 & 46 & 21 & 3 & 49 & 4 \\
\hline Florida & $16,681,144$ & 15,250 & 1,783 & 1,146 & 684 & 568 & 835 & 352 & 28 & 1,042 & 59 \\
\hline Georgia & $8,539,735$ & 6,374 & 1,253 & 584 & 263 & 296 & 344 & 76 & 0 & 551 & 24 \\
\hline Hawaii & $1,234,514$ & 1,226 & 91 & 87 & 42 & 28 & 56 & 21 & 0 & 65 & 16 \\
\hline Idaho & $1,343,194$ & 923 & 162 & 87 & 54 & 37 & 54 & 9 & 1 & 100 & 10 \\
\hline Illinois & $12,585,204$ & 9,383 & 1,277 & 862 & 582 & 394 & 545 & 180 & 19 & 716 & 108 \\
\hline Indiana & $6,158,327$ & 4,697 & 861 & 422 & 222 & 330 & 237 & 88 & 3 & 416 & 27 \\
\hline Iowa & $2,934,776$ & 2,128 & 401 & 196 & 139 & 111 & 114 & 39 & 1 & 244 & 17 \\
\hline Kansas & $2,712,896$ & 1,819 & 316 & 188 & 118 & 93 & 95 & 23 & 2 & 172 & 9 \\
\hline Kentucky & $4,089,985$ & 2,732 & 600 & 261 & 120 & 255 & 141 & 33 & 10 & 266 & 11 \\
\hline Louisiana & $4,477,042$ & 3,066 & 549 & 341 & 144 & 193 & 207 & 71 & 7 & 268 & 58 \\
\hline Maine & $1,297,750$ & 1,067 & 159 & 87 & 39 & 46 & 59 & 12 & 1 & 73 & 25 \\
\hline Maryland & $5,441,531$ & 4,353 & 600 & 367 & 228 & 134 & 226 & 66 & 9 & 288 & 16 \\
\hline Massachusetts & $6,412,554$ & 5,566 & 634 & 490 & 376 & 157 & 314 & 102 & 7 & 390 & 20 \\
\hline Michigan & $10,042,495$ & 7,741 & 1,186 & 660 & 367 & 347 & 414 & 145 & 6 & 627 & 53 \\
\hline Minnesota & $5,025,081$ & 4,174 & 632 & 342 & 204 & 157 & 241 & 71 & 1 & 334 & 26 \\
\hline Mississippi & $2,867,635$ & 1,815 & 411 & 198 & 83 & 116 & 117 & 14 & 0 & 144 & 14 \\
\hline Missouri & $5,679,770$ & 4,340 & 795 & 394 & 208 & 248 & 247 & 87 & 0 & 311 & 21 \\
\hline Montana & 910,670 & 623 & 136 & 61 & 27 & 30 & 45 & 15 & 0 & 77 & 13 \\
\hline Nebraska & $1,726,437$ & 1,249 & 240 & 121 & 83 & 59 & 73 & 15 & 2 & 121 & 15 \\
\hline Nevada & $2,168,304$ & 2,885 & 249 & 167 & 70 & 77 & 151 & 73 & 8 & 93 & 9 \\
\hline New Hampshire & $1,275,607$ & 1,396 & 157 & 89 & 49 & 74 & 106 & 19 & 5 & 83 & 16 \\
\hline New Jersey & $8,577,250$ & 7,529 & 966 & 660 & 452 & 220 & 370 & 102 & 20 & 489 & 38 \\
\hline New Mexico & $1,855,143$ & 1,302 & 248 & 113 & 46 & 42 & 83 & 40 & 2 & 109 & 30 \\
\hline New York & $19,151,066$ & 13,978 & 1,308 & 1,447 & 878 & 393 & 713 & 339 & 48 & 756 & 36 \\
\hline North Carolina & $8,311,899$ & 6,269 & 998 & 592 & 286 & 359 & 309 & 98 & 0 & 454 & 28 \\
\hline North Dakota & 633,799 & 501 & 98 & 46 & 22 & 19 & 34 & 8 & 3 & 52 & 16 \\
\hline Ohio & $11,410,396$ & 8,425 & 1,289 & 776 & 429 & 490 & 437 & 140 & 10 & 774 & 31 \\
\hline Oklahoma & $3,488,201$ & 2,176 & 533 & 230 & 98 & 157 & 121 & 35 & 3 & 234 & 13 \\
\hline
\end{tabular}




\begin{tabular}{|c|c|c|c|c|c|c|c|c|c|c|c|}
\hline State & $\begin{array}{c}2002 \\
\text { population }\end{array}$ & $\begin{array}{l}\text { General sales } \\
\text { tax capacity }\end{array}$ & $\begin{array}{l}\text { Motor } \\
\text { fuels tax } \\
\text { capacity }\end{array}$ & $\begin{array}{c}\text { Public } \\
\text { utilities tax } \\
\text { capacity }\end{array}$ & $\begin{array}{c}\text { Insurance } \\
\text { tax } \\
\text { capacity }\end{array}$ & $\begin{array}{l}\text { Tobacco } \\
\text { tax } \\
\text { capacity }\end{array}$ & $\begin{array}{l}\text { Alcohol } \\
\text { (beer, wine, } \\
\text { and spirits) } \\
\text { tax capacity }\end{array}$ & $\begin{array}{l}\text { Amusement } \\
\text { tax capacity }\end{array}$ & $\begin{array}{c}\text { Pari- } \\
\text { mutuels } \\
\text { tax } \\
\text { capacity }\end{array}$ & $\begin{array}{c}\text { Motor } \\
\text { vehicle } \\
\text { license tax } \\
\text { capacity }\end{array}$ & $\begin{array}{c}\text { Motor } \\
\text { vehicle } \\
\text { operator } \\
\text { license tax } \\
\text { capacity }\end{array}$ \\
\hline Oregon & $3,523,281$ & 2,772 & 364 & 226 & 110 & 103 & 155 & 38 & 3 & 225 & 15 \\
\hline Pennsylvania & $12,328,459$ & 8,990 & 1,283 & 888 & 497 & 475 & 458 & 147 & 20 & 705 & 34 \\
\hline Rhode Island & $1,068,897$ & 781 & 91 & 68 & 40 & 35 & 50 & 15 & 2 & 57 & 23 \\
\hline South Carolina & $4,105,848$ & 2,852 & 581 & 315 & 130 & 176 & 182 & 36 & 0 & 234 & 15 \\
\hline South Dakota & 760,452 & 590 & 103 & 47 & 30 & 25 & 34 & 11 & 1 & 60 & 42 \\
\hline Tennessee & $5,792,297$ & 4,293 & 753 & 409 & 183 & 264 & 207 & 62 & 0 & 365 & 37 \\
\hline Texas & $21,723,220$ & 16,285 & 2,821 & 1,661 & 774 & 553 & 870 & 196 & 10 & 1,072 & 65 \\
\hline Utah & $2,319,743$ & 1,719 & 264 & 129 & 66 & 40 & 54 & 54 & 0 & 133 & 34 \\
\hline Vermont & 616,500 & 521 & 82 & 44 & 22 & 25 & 28 & 10 & 0 & 39 & 10 \\
\hline Virginia & $7,273,572$ & 5,734 & 941 & 518 & 256 & 294 & 274 & 92 & 2 & 458 & 28 \\
\hline Washington & $6,067,146$ & 4,636 & 642 & 394 & 186 & 120 & 252 & 104 & 2 & 387 & 46 \\
\hline West Virginia & $1,805,230$ & 1,165 & 217 & 118 & 49 & 89 & 60 & 30 & 4 & 107 & 7 \\
\hline Wisconsin & $5,440,367$ & 4,062 & 626 & 359 & 207 & 182 & 300 & 71 & 2 & 332 & 23 \\
\hline Wyoming & 499,192 & 384 & 127 & 43 & 15 & 20 & 25 & 5 & 0 & 43 & 3 \\
\hline
\end{tabular}


Table D8. Summary data, revenue capacity (\$millions), FY2002, part II

\begin{tabular}{|c|c|c|c|c|c|c|c|c|c|c|c|c|c|}
\hline State & $\begin{array}{c}\text { Corporation } \\
\text { license tax } \\
\text { capacity }\end{array}$ & $\begin{array}{l}\text { Fishing } \\
\text { and } \\
\text { hunting } \\
\text { license tax } \\
\text { capacity }\end{array}$ & $\begin{array}{l}\text { Personal } \\
\text { income } \\
\text { tax } \\
\text { capacity }\end{array}$ & $\begin{array}{l}\text { Corporate } \\
\text { income } \\
\text { tax } \\
\text { capacity }\end{array}$ & $\begin{array}{l}\text { Property } \\
\text { tax } \\
\text { capacity }\end{array}$ & $\begin{array}{l}\text { Death and } \\
\text { gift tax } \\
\text { capacity }\end{array}$ & $\begin{array}{l}\text { Severance } \\
\text { tax } \\
\text { capacity }\end{array}$ & $\begin{array}{l}\text { All other } \\
\text { tax } \\
\text { capacity }\end{array}$ & $\begin{array}{l}\text { Total tax } \\
\text { capacity }\end{array}$ & $\begin{array}{l}\text { Revenue } \\
\text { capacity } \\
\text { lotteries }\end{array}$ & $\begin{array}{c}\text { Revenue } \\
\text { capacity } \\
\text { user } \\
\text { charges }\end{array}$ & $\begin{array}{c}\text { Revenue } \\
\text { capacity other } \\
\text { nontax } \\
\text { revenues }\end{array}$ & $\begin{array}{c}\text { Total } \\
\text { revenue } \\
\text { capacity }\end{array}$ \\
\hline United States & 5,842 & 1,182 & 201,909 & $\quad 27,941$ & 278,318 & 7,384 & 4,234 & 51,838 & 909,212 & 15,766 & 264,225 & 149,758 & $1,338,961$ \\
\hline Alabama & 66 & 21 & 2,405 & 305 & 3,193 & 87 & 84 & 667 & 11,577 & 214 & 3,400 & 1,927 & 17,118 \\
\hline Alaska & 11 & 14 & 516 & 62 & 734 & 4 & 263 & 121 & 2,537 & 16 & 619 & 351 & 3,522 \\
\hline Arizona & 97 & 16 & 3,287 & 438 & 4,719 & 85 & 67 & 845 & 15,685 & 124 & 4,305 & 2,440 & 22,555 \\
\hline Arkansas & 50 & 30 & 1,355 & 168 & 1,834 & 23 & 33 & 371 & 6,551 & 122 & 1,889 & 1,070 & 9,632 \\
\hline California & 513 & 68 & 26,713 & 3,176 & 43,868 & 1175 & 335 & 6,725 & 122,124 & 1,183 & 34,277 & 19,428 & 177,011 \\
\hline Colorado & 127 & 27 & 3,567 & 442 & 5,489 & 89 & 112 & 897 & 16,425 & 170 & 4,571 & 2,591 & 23,758 \\
\hline Connecticut & 62 & 6 & 3,612 & 534 & 4,427 & 165 & 4 & 861 & 14,173 & 645 & 4,390 & 2,488 & 21,696 \\
\hline Delaware & 23 & 1 & 687 & 351 & 766 & 49 & 1 & 155 & 3,290 & 45 & 792 & 449 & 4,577 \\
\hline Florida & 580 & 28 & 11,448 & 1,271 & 16,423 & 597 & 51 & 2,903 & 55,049 & 668 & 14,798 & 8,387 & 78,902 \\
\hline Georgia & 183 & 21 & 5,628 & 773 & 7,206 & 126 & 42 & 1,435 & 25,178 & 477 & 7,316 & 4,146 & 37,118 \\
\hline Hawaii & 27 & 9 & 816 & 81 & 1,387 & 25 & 36 & 213 & 4,226 & 56 & 1,086 & 616 & 5,984 \\
\hline Idaho & 27 & 24 & 711 & 88 & 1,138 & 11 & 12 & 198 & 3,646 & 29 & 1,011 & 573 & 5,259 \\
\hline Illinois & 290 & 49 & 9,798 & 1,433 & 12,559 & 375 & 77 & 2,424 & 41,071 & 526 & 12,356 & 7,003 & 60,956 \\
\hline Indiana & 110 & 26 & 3,865 & 514 & 5,142 & 126 & 22 & 1,011 & 18,119 & 339 & 5,151 & 2,920 & 26,529 \\
\hline Iowa & 57 & 12 & 1,763 & 299 & 2,829 & 41 & 10 & 483 & 8,884 & 79 & 2,461 & 1,395 & 12,819 \\
\hline Kansas & 49 & 7 & 1,726 & 223 & 2,286 & 54 & 84 & 461 & 7,725 & 55 & 2,348 & 1,331 & 11,458 \\
\hline Kentucky & 68 & 13 & 2,303 & 298 & 4,418 & 51 & 21 & 609 & 12,210 & 185 & 3,102 & 1,758 & 17,255 \\
\hline Louisiana & 92 & 30 & 2,373 & 340 & 2,824 & 51 & 543 & 661 & 11,815 & 127 & 3,367 & 1,908 & 17,218 \\
\hline Maine & 29 & 20 & 789 & 89 & 1,127 & 30 & 27 & 211 & 3,889 & 61 & 1,075 & 609 & 5,634 \\
\hline Maryland & 99 & 7 & 3,952 & 487 & 5,404 & 168 & 8 & 1,165 & 17,579 & 361 & 5,938 & 3,366 & 27,243 \\
\hline Massachusetts & 139 & 13 & 6,276 & 815 & 8,513 & 266 & 8 & 1,465 & 25,552 & 1,190 & 7,465 & 4,231 & 38,437 \\
\hline Michigan & 201 & 50 & 6,947 & 983 & 9,190 & 167 & 71 & 1,778 & 30,934 & 329 & 9,063 & 5,137 & 45,464 \\
\hline Minnesota & 116 & 41 & 3,987 & 658 & 5,297 & 134 & 33 & 978 & 17,426 & 173 & 4987 & 2,826 & 25,412 \\
\hline Mississippi & 41 & 18 & 1,274 & 148 & 1,718 & 29 & 34 & 375 & 6,548 & 70 & 1,911 & 1,083 & 9,612 \\
\hline Missouri & 101 & 26 & 3,738 & 541 & 4,685 & 170 & 31 & 944 & 16,887 & 259 & 4,812 & 2,727 & 24,684 \\
\hline Montana & 26 & 22 & 493 & 53 & 949 & 14 & 37 & 134 & 2,755 & 9 & 682 & 386 & 3,832 \\
\hline Nebraska & 39 & 17 & 1,123 & 160 & 1,611 & 27 & 9 & 295 & 5,261 & 30 & 1,505 & 853 & 7,649 \\
\hline Nevada & 60 & 9 & 1,635 & 206 & 1,875 & 36 & 49 & 390 & 8,042 & 152 & 1,990 & 1,128 & 11,313 \\
\hline New Hampshire & 25 & 10 & 954 & 118 & 1,525 & 31 & 7 & 254 & 4,917 & 45 & 1,296 & 735 & 6,993 \\
\hline New Jersey & 256 & 7 & 7,402 & 1,096 & 10,039 & 265 & 8 & 1,975 & 31,895 & 802 & 10,065 & 5,705 & 48,467 \\
\hline New Mexico & 29 & 34 & 1,046 & 118 & 1,343 & 35 & 263 & 264 & 5,146 & 70 & 1,344 & 762 & 7,321 \\
\hline New York & 552 & 56 & 17,352 & 3,063 & 21,166 & 896 & 38 & 3,970 & 66,989 & 1,654 & 20,237 & 11,470 & 100,351 \\
\hline North Carolina & 157 & 24 & 5,219 & 705 & 7,465 & 144 & 14 & 1,340 & 24461 & 426 & 6,830 & 3,871 & 35,588 \\
\hline North Dakota & 12 & 23 & 381 & 48 & 575 & 7 & 52 & 98 & 1,994 & 13 & 500 & 283 & 2,790 \\
\hline Ohio & 194 & 28 & 7,691 & 1,083 & 9,446 & 240 & 44 & 1,952 & 33,480 & 908 & 9,950 & 5,640 & 49,978 \\
\hline
\end{tabular}




\begin{tabular}{|c|c|c|c|c|c|c|c|c|c|c|c|c|c|}
\hline State & $\begin{array}{c}\text { Corporation } \\
\text { license tax } \\
\text { capacity }\end{array}$ & $\begin{array}{l}\text { Fishing } \\
\text { and } \\
\text { hunting } \\
\text { license tax } \\
\text { capacity }\end{array}$ & $\begin{array}{l}\text { Personal } \\
\text { income } \\
\text { tax } \\
\text { capacity }\end{array}$ & $\begin{array}{l}\text { Corporate } \\
\text { income } \\
\text { tax } \\
\text { capacity }\end{array}$ & $\begin{array}{l}\text { Property } \\
\text { tax } \\
\text { capacity }\end{array}$ & $\begin{array}{l}\text { Death and } \\
\text { gift tax } \\
\text { capacity }\end{array}$ & $\begin{array}{c}\text { Severance } \\
\text { tax } \\
\text { capacity }\end{array}$ & $\begin{array}{l}\text { All other } \\
\text { tax } \\
\text { capacity }\end{array}$ & $\begin{array}{l}\text { Total tax } \\
\text { capacity }\end{array}$ & $\begin{array}{l}\text { Revenue } \\
\text { capacity } \\
\text { lotteries }\end{array}$ & $\begin{array}{l}\text { Revenue } \\
\text { capacity } \\
\text { user } \\
\text { charges }\end{array}$ & $\begin{array}{c}\text { Revenue } \\
\text { capacity other } \\
\text { nontax } \\
\text { revenues }\end{array}$ & $\begin{array}{c}\text { Total } \\
\text { revenue } \\
\text { capacity }\end{array}$ \\
\hline Oklahoma & 65 & 19 & 1,830 & 248 & 2,437 & 56 & 228 & 528 & 9,010 & 147 & 2,693 & 1,526 & 13,377 \\
\hline Oregon & 72 & 17 & 2,337 & 284 & 3,640 & 90 & 50 & 597 & 11,098 & 446 & 3,043 & 1,725 & 16,311 \\
\hline Pennsylvania & 202 & 32 & 8,538 & 1,242 & 9,980 & 320 & 24 & 2,240 & 36,073 & 505 & 11,416 & 6,471 & 54,465 \\
\hline Rhode Island & 25 & 4 & 731 & 90 & 977 & 23 & 6 & 197 & 3,215 & 235 & 1,005 & 569 & 5,024 \\
\hline South Carolina & 75 & 15 & 2,281 & 285 & 2,978 & 56 & 17 & 610 & 10,838 & 148 & 3,107 & 1,761 & 15,855 \\
\hline South Dakota & 15 & 30 & 446 & 57 & 679 & 6 & 21 & 121 & 2,318 & 25 & 615 & 349 & 3,307 \\
\hline Tennessee & 68 & 39 & 3,504 & 465 & 4,521 & 102 & 23 & 933 & 16,228 & 300 & 4,754 & 2,694 & 23,976 \\
\hline Texas & 355 & 49 & 13,785 & 2,101 & 16,506 & 391 & 996 & 3,671 & 62,163 & 1,302 & 18,714 & 10,607 & 92,786 \\
\hline Utah & 50 & 26 & 1,340 & 169 & 1,960 & 25 & 68 & 341 & 6,471 & 52 & 1,737 & 985 & 9,245 \\
\hline Vermont & 17 & 16 & 411 & 47 & 593 & 20 & 9 & 106 & 1,999 & 30 & 539 & 306 & 2874 \\
\hline Virginia & 139 & 26 & 4,289 & 612 & 7,725 & 192 & 16 & 1,409 & 23,007 & 288 & 7184 & 4,072 & 34,550 \\
\hline Washington & 117 & 41 & 4,598 & 484 & 6,655 & 162 & 28 & 1,157 & 20,012 & 302 & 5,897 & 3,342 & 29,554 \\
\hline West Virginia & 22 & 8 & 864 & 105 & 1,102 & 19 & 4 & 254 & 4,223 & 163 & 1,294 & 733 & 6,412 \\
\hline Wisconsin & 94 & 39 & 3,764 & 532 & 4,860 & 118 & 14 & 957 & 16,543 & 197 & 4,877 & 2,764 & 24,382 \\
\hline Wyoming & 14 & 11 & 360 & 50 & 535 & 13 & 203 & 91 & 1,943 & 14 & 462 & 262 & 2,681 \\
\hline
\end{tabular}


Table D9. Summary data, actual revenues (\$millions), FY2002, part I

\begin{tabular}{|c|c|c|c|c|c|c|c|c|c|c|c|}
\hline State & $\begin{array}{c}\text { General } \\
\text { sales }\end{array}$ & $\begin{array}{l}\text { Motor } \\
\text { fuels }\end{array}$ & $\begin{array}{c}\text { Public } \\
\text { utilities }\end{array}$ & Insurance & Tobacco & Alcohol & Amusement & Pari-mutuels & $\begin{array}{c}\text { Motor vehicle } \\
\text { licenses }\end{array}$ & $\begin{array}{c}\text { Motor vehicle } \\
\text { operator } \\
\text { licenses }\end{array}$ & $\begin{array}{c}\text { Corporation } \\
\text { licenses }\end{array}$ \\
\hline United States & 222,428 & 33,009 & 20,097 & 11,158 & 9,076 & 12,046 & 4,079 & 308 & 16,925 & 1,419 & 5,842 \\
\hline Alabama & 2,968 & 557 & 580 & 220 & 79 & 284 & 0 & 4 & 207 & 13 & 72 \\
\hline Alaska & 122 & 40 & 9 & 37 & 51 & 20 & 3 & - & 47 & - & 1 \\
\hline Arizona & 5,783 & 625 & 178 & 199 & 162 & 191 & 1 & 1 & 153 & 15 & 8 \\
\hline Arkansas & 2,541 & 414 & 87 & 112 & 93 & 60 & - & 4 & 107 & 22 & 10 \\
\hline California & 31,293 & 3,296 & 2,816 & 1,596 & 1,103 & 748 & - & 45 & 1,740 & 151 & 48 \\
\hline Colorado & 4,128 & 569 & 114 & 158 & 66 & 181 & 95 & 6 & 184 & 17 & 7 \\
\hline Connecticut & 3,044 & 425 & 167 & 207 & 158 & 112 & 365 & 7 & 241 & 34 & 17 \\
\hline Delaware & - & 108 & 33 & 76 & 28 & 12 & - & 0 & 32 & 0 & 534 \\
\hline Florida & 15,034 & 2,379 & 2,920 & 414 & 466 & 1,441 & - & 30 & 957 & 121 & 128 \\
\hline Georgia & 7,493 & 650 & 208 & 296 & 94 & 443 & - & - & 269 & 24 & 41 \\
\hline Hawaii & 1,612 & 143 & 154 & 70 & 66 & 69 & - & - & 133 & 0 & 2 \\
\hline Idaho & 796 & 214 & 16 & 66 & 28 & 49 & - & - & 116 & 6 & 1 \\
\hline Illinois & 7,528 & 1,562 & 2,363 & 285 & 530 & 489 & 591 & 13 & 1,458 & 72 & 165 \\
\hline Indiana & 3,798 & 742 & 19 & 179 & 123 & 133 & 521 & 5 & 301 & - & 6 \\
\hline Iowa & 2,016 & 343 & 36 & 136 & 94 & 111 & 202 & 3 & 378 & 8 & 32 \\
\hline Kansas & 2,295 & 377 & 122 & 97 & 52 & 91 & 1 & 4 & 145 & 12 & 29 \\
\hline Kentucky & 2,312 & 461 & 179 & 258 & 17 & 132 & 0 & 18 & 214 & 12 & 181 \\
\hline Louisiana & 4,838 & 559 & 160 & 288 & 129 & 134 & 497 & 6 & 118 & 11 & 265 \\
\hline Maine & 836 & 192 & 7 & 60 & 94 & 82 & - & 5 & 105 & 10 & 3 \\
\hline Maryland & 2,690 & 703 & 279 & 197 & 210 & 115 & 5 & 3 & 200 & 20 & 15 \\
\hline Massachusetts & 3,696 & 667 & - & 361 & 275 & 111 & 6 & 7 & 270 & 58 & 19 \\
\hline Michigan & 7,784 & 1,090 & 77 & 227 & 670 & 509 & 92 & 12 & 891 & 43 & 12 \\
\hline Minnesota & 3,782 & 620 & 69 & 163 & 174 & 237 & 56 & 1 & 497 & 31 & 5 \\
\hline Mississippi & 2,341 & 417 & 51 & 130 & 56 & 145 & 184 & - & 112 & 24 & 62 \\
\hline Missouri & 4,246 & 695 & 357 & 217 & 124 & 123 & 220 & - & 249 & 21 & 20 \\
\hline Montana & - & 191 & 31 & 51 & 13 & 26 & 44 & 0 & 127 & 4 & 2 \\
\hline Nebraska & 1,287 & 308 & 91 & 38 & 44 & 59 & 6 & 1 & 104 & 8 & 6 \\
\hline Nevada & 2,217 & 414 & 144 & 156 & 64 & 156 & 721 & - & 130 & 13 & 36 \\
\hline New & & 120 & 64 & 69 & & 114 & 2 & 4 & 77 & 14 & 4 \\
\hline Hampshire & - & & & & 83 & & & & & & \\
\hline New Jersey & 5,997 & 524 & 840 & 346 & 407 & 383 & 351 & - & 372 & 32 & 122 \\
\hline New Mexico & 1,765 & 200 & 50 & 52 & 18 & 80 & 32 & 1 & 119 & 6 & 2 \\
\hline New York & 16,630 & 492 & 1,770 & 585 & 1,038 & 820 & 1 & 38 & 808 & 106 & 66 \\
\hline North Carolina & 4,909 & 1,209 & 407 & 348 & 42 & 409 & 11 & - & 437 & 69 & 274 \\
\hline North Dakota & 395 & 111 & 38 & 26 & 22 & 28 & 14 & 3 & 52 & 4 & - \\
\hline Ohio & 7,687 & 1,376 & 827 & 366 & 286 & 441 & - & 17 & 718 & 42 & 264 \\
\hline Oklahoma & 2,600 & 410 & 109 & 149 & 72 & 110 & 7 & 3 & 570 & 12 & 44 \\
\hline Oregon & - & 409 & 143 & 54 & 176 & 111 & 0 & 2 & 275 & 27 & 0 \\
\hline
\end{tabular}




\begin{tabular}{|c|c|c|c|c|c|c|c|c|c|c|c|}
\hline State & $\begin{array}{c}\text { General } \\
\text { sales }\end{array}$ & $\begin{array}{l}\text { Motor } \\
\text { fuels }\end{array}$ & $\begin{array}{c}\text { Public } \\
\text { utilities }\end{array}$ & Insurance & Tobacco & Alcohol & Amusement & Pari-mutuels & $\begin{array}{c}\text { Motor vehicle } \\
\text { licenses }\end{array}$ & $\begin{array}{c}\text { Motor vehicle } \\
\text { operator } \\
\text { licenses }\end{array}$ & $\begin{array}{c}\text { Corporation } \\
\text { licenses }\end{array}$ \\
\hline Pennsylvania & 7,500 & 1,753 & 749 & 503 & 317 & 523 & 1 & 29 & 771 & 54 & 698 \\
\hline Rhode Island & 732 & 130 & 80 & 32 & 83 & 73 & - & 5 & 53 & 1 & 12 \\
\hline South Carolina & 2,435 & 411 & 114 & 113 & 27 & 219 & 29 & - & 110 & 21 & 59 \\
\hline South Dakota & 672 & 123 & 4 & 45 & 19 & 43 & 0 & 1 & 66 & 2 & 2 \\
\hline Tennessee & 5,842 & 814 & 55 & 283 & 84 & 273 & - & - & 342 & 40 & 421 \\
\hline Texas & 18,322 & 2,835 & 1,616 & 972 & 540 & 1,039 & 21 & 13 & 1,292 & 115 & 1,991 \\
\hline Utah & 1,970 & 336 & 81 & 88 & 51 & 102 & - & - & 86 & 9 & 2 \\
\hline Vermont & 215 & 71 & 10 & 36 & 27 & 33 & - & - & 41 & 3 & 2 \\
\hline Virginia & 3,587 & 849 & 591 & 293 & 52 & 342 & 0 & - & 447 & 30 & 30 \\
\hline Washington & 9,231 & 743 & 735 & 291 & 331 & 407 & 0 & 2 & 338 & 41 & 16 \\
\hline West Virginia & 963 & 300 & 219 & 89 & 32 & 51 & - & 12 & 88 & 4 & 7 \\
\hline Wisconsin & 3,914 & 955 & 315 & 107 & 303 & 156 & 0 & 2 & 314 & 33 & 89 \\
\hline Wyoming & 580 & 75 & 14 & 15 & 5 & 17 & - & 0 & 63 & 3 & 8 \\
\hline
\end{tabular}


Table D10. Summary data, actual revenues (\$millions), FY2002, part II

\begin{tabular}{|c|c|c|c|c|c|c|c|c|c|c|c|}
\hline State & $\begin{array}{c}\text { Fishing and } \\
\text { hunting licenses }\end{array}$ & $\begin{array}{c}\text { Personal } \\
\text { income taxes }\end{array}$ & $\begin{array}{c}\text { Corporate } \\
\text { income taxes }\end{array}$ & $\begin{array}{l}\text { Property } \\
\text { taxes }\end{array}$ & $\begin{array}{l}\text { Death and } \\
\text { gift taxes }\end{array}$ & $\begin{array}{c}\text { Severance } \\
\text { taxes }\end{array}$ & $\begin{array}{l}\text { All other } \\
\text { taxes }\end{array}$ & $\begin{array}{l}\text { Revenues } \\
\text { from lotteries }\end{array}$ & $\begin{array}{c}\text { User } \\
\text { charges and } \\
\text { fees }\end{array}$ & $\begin{array}{l}\text { All other nontax } \\
\text { revenues }\end{array}$ & $\begin{array}{c}\text { Total } \\
\text { revenues }\end{array}$ \\
\hline United States & 1,182 & 201,909 & 27,941 & 278,318 & 7,384 & 4,234 & 51,838 & 15,766 & 264,225 & 149,758 & $1,338,934$ \\
\hline Alabama & 15 & 2,127 & 323 & 1,474 & 83 & 66 & 771 & - & 6,005 & 1,767 & 17,613 \\
\hline Alaska & 20 & - & 269 & 830 & 3 & 551 & 70 & - & 741 & 2,654 & 5,471 \\
\hline Arizona & 20 & 2,091 & 346 & 4,254 & 82 & 6 & 444 & 115 & 2,977 & 2,377 & 20,027 \\
\hline Arkansas & 21 & 1,566 & 177 & 1,004 & 39 & 13 & 217 & - & 2,012 & 1,194 & 9,694 \\
\hline California & 74 & 33,047 & 5,333 & 30,243 & 1,000 & 29 & 8,318 & 1,196 & 38,185 & 20,771 & 181,031 \\
\hline Colorado & 57 & 3,476 & 205 & 4,162 & 72 & 57 & 497 & 138 & 4,682 & 3,131 & 22,002 \\
\hline Connecticut & 3 & 3,685 & 149 & 5,995 & 160 & - & 426 & 364 & 1,765 & 1,513 & 18,839 \\
\hline Delaware & 1 & 763 & 252 & 400 & 41 & - & 408 & 338 & 1,088 & 708 & 4,822 \\
\hline Florida & 13 & - & 1,219 & 15,754 & 752 & 40 & 4,065 & 1,037 & 15,789 & 10,807 & 73,366 \\
\hline Georgia & 23 & 6,488 & 568 & 6,640 & 123 & - & 884 & 855 & 7,012 & 3,126 & 35,237 \\
\hline Hawaii & 0 & 1,112 & 53 & 615 & 17 & - & 223 & - & 1,055 & 605 & 5,929 \\
\hline Idaho & 30 & 842 & 77 & 959 & 10 & 4 & 122 & 33 & 1,370 & 582 & 5,318 \\
\hline Illinois & 25 & 7,471 & 1,384 & 15,873 & 329 & 0 & 1,735 & 594 & 8,331 & 6,332 & 57,131 \\
\hline Indiana & 23 & 4,121 & 709 & 5,976 & 142 & 1 & 283 & 197 & 5,896 & 3,134 & 26,308 \\
\hline Iowa & 20 & 1,814 & 88 & 2,878 & 80 & - & 187 & 70 & 3,316 & 1,557 & 13,372 \\
\hline Kansas & 17 & 1,855 & 122 & 2,525 & 48 & 67 & 126 & 81 & 2,172 & 1,397 & 11,635 \\
\hline Kentucky & 22 & 3,496 & 302 & 1,977 & 85 & 187 & 986 & 255 & 2,891 & 1,958 & 15,944 \\
\hline Louisiana & 33 & 1,789 & 264 & 1,940 & 69 & 494 & 668 & 129 & 4,491 & 2,811 & 19,692 \\
\hline Maine & 9 & 1,073 & 77 & 1,912 & 23 & - & 91 & 54 & 874 & 780 & 6,287 \\
\hline Maryland & 11 & 7,644 & 359 & 5,412 & 183 & - & 1,917 & 573 & 4,149 & 2,024 & 26,710 \\
\hline Massachusetts & 6 & 7,913 & 812 & 8,722 & 201 & - & 818 & 1,201 & 4,160 & 3,906 & 33,208 \\
\hline Michigan & 49 & 6,598 & 2,065 & 9,793 & 131 & 32 & 933 & 685 & 9,450 & 4,745 & 45,890 \\
\hline Minnesota & 51 & 5,443 & 534 & 5,215 & 66 & 13 & 1,678 & 130 & 4,958 & 3,645 & 27,369 \\
\hline Mississippi & 13 & 985 & 196 & 1,647 & 30 & 32 & 204 & - & 3,098 & 1,077 & 10,804 \\
\hline Missouri & 29 & 3,929 & 300 & 3,880 & 134 & - & 676 & 196 & 3,910 & 2,532 & 21,859 \\
\hline Montana & 33 & 518 & 68 & 852 & 14 & 89 & 79 & 15 & 809 & 634 & 3,600 \\
\hline Nebraska & 14 & 1,153 & 108 & 1,749 & 16 & 1 & 364 & 35 & 1,463 & 1,062 & 7,917 \\
\hline Nevada & 7 & - & - & 1,702 & 30 & 21 & 762 & - & 2,288 & 1,156 & 10,016 \\
\hline New & 8 & 71 & 377 & 2,169 & 56 & - & 468 & 80 & 876 & 626 & 5,283 \\
\hline \multicolumn{12}{|l|}{ Hampshire } \\
\hline New Jersey & 14 & 6,867 & 1,101 & 16,050 & 510 & - & 1,015 & 839 & 7,835 & 4,037 & 47,641 \\
\hline New Mexico & 17 & 983 & 124 & 756 & 19 & 453 & 244 & 47 & 1,256 & 1,589 & 7,814 \\
\hline New York & 34 & 30,208 & 5,075 & 26,826 & 768 & - & 4,233 & 1,827 & 20,312 & 10,471 & 122,107 \\
\hline North Carolina & 15 & 7,265 & 668 & 5,422 & 118 & 2 & 1,168 & - & 8,592 & 2,804 & 34,172 \\
\hline North Dakota & 10 & 200 & 50 & 532 & 5 & 138 & 124 & - & 723 & 403 & 2,878 \\
\hline Ohio & 28 & 11,794 & 761 & 10,643 & 116 & 9 & 1,136 & 835 & 9,363 & 5,597 & 52,306 \\
\hline Oklahoma & 16 & 2,286 & 174 & 1,482 & 86 & 364 & 333 & - & 3,443 & 1,601 & 13,871 \\
\hline Oregon & 33 & 3,675 & 196 & 3,139 & 65 & 30 & 765 & 411 & 4,114 & 1,879 & 15,505 \\
\hline Pennsylvania & 60 & 9,510 & 1,198 & 10,911 & 762 & - & 2,612 & 773 & 11,599 & 6,455 & 56,780 \\
\hline Rhode Island & 1 & 824 & 28 & 1,462 & 19 & - & 150 & 217 & 568 & 476 & 4,946 \\
\hline South Carolina & 15 & 2,349 & 160 & 3,096 & 64 & - & 624 & 135 & 4,623 & 1,440 & 16,045 \\
\hline
\end{tabular}




\begin{tabular}{|c|c|c|c|c|c|c|c|c|c|c|c|}
\hline State & $\begin{array}{c}\text { Fishing and } \\
\text { hunting licenses }\end{array}$ & $\begin{array}{c}\text { Personal } \\
\text { income taxes }\end{array}$ & $\begin{array}{c}\text { Corporate } \\
\text { income taxes }\end{array}$ & $\begin{array}{c}\text { Property } \\
\text { taxes }\end{array}$ & $\begin{array}{l}\text { Death and } \\
\text { gift taxes }\end{array}$ & $\begin{array}{c}\text { Severance } \\
\text { taxes }\end{array}$ & $\begin{array}{c}\text { All other } \\
\text { taxes }\end{array}$ & $\begin{array}{c}\text { Revenues } \\
\text { from lotteries }\end{array}$ & $\begin{array}{c}\text { User } \\
\text { charges and } \\
\text { fees }\end{array}$ & $\begin{array}{c}\text { All other nontax } \\
\text { revenues }\end{array}$ & $\begin{array}{c}\text { Total } \\
\text { revenues }\end{array}$ \\
\hline South Dakota & 22 & - & 41 & 668 & 23 & 2 & 139 & 117 & 446 & 369 & 2,805 \\
\hline Tennessee & 25 & 146 & 503 & 3,453 & 100 & 1 & 688 & - & 5,153 & 1,765 & 19,988 \\
\hline Texas & 64 & 0 & - & 24,521 & 333 & 975 & 4,805 & 1,098 & 16,745 & 9,975 & 87,273 \\
\hline Utah & 22 & 1,605 & 111 & 1,420 & 9 & 29 & 180 & - & 2,557 & 1,356 & 10,016 \\
\hline Vermont & 6 & 408 & 37 & 824 & 14 & - & 256 & 25 & 441 & 344 & 2,792 \\
\hline Virginia & 20 & 6,711 & 309 & 6,711 & 134 & 2 & 2,234 & 432 & 6,657 & 3,708 & 33,138 \\
\hline Washington & 31 & - & - & 5,791 & 114 & 43 & 1,633 & 156 & 6,908 & 3,035 & 29,845 \\
\hline West Virginia & 16 & 1,035 & 220 & 901 & 13 & 177 & 553 & 329 & 1,407 & 831 & 7,247 \\
\hline Wisconsin & 59 & 4,974 & 445 & 6,466 & 83 & 3 & 502 & 155 & 4,964 & 2,477 & 26,317 \\
\hline Wyoming & 26 & - & - & 692 & 10 & 302 & 26 & - & 705 & 535 & 3,075 \\
\hline
\end{tabular}


Table D11. Representative state and local expenditures by function, adjusted for input cost differences and normalized, FY 2002 (per capita dollars)

\begin{tabular}{|c|c|c|c|c|c|c|c|c|c|c|c|c|c|}
\hline State & $\begin{array}{l}\text { Elem and } \\
\text { secondary } \\
\text { education }\end{array}$ & $\begin{array}{l}\text { Higher } \\
\text { ed }\end{array}$ & $\begin{array}{l}\text { Pub. } \\
\text { welf. }\end{array}$ & $\begin{array}{l}\text { Health } \\
\text { and } \\
\text { hosp. }\end{array}$ & Highways & $\begin{array}{l}\text { Police } \\
\text { and } \\
\text { corrects. }\end{array}$ & $\begin{array}{l}\text { Environ. } \\
\text { and } \\
\text { housing }\end{array}$ & $\begin{array}{l}\text { Gov. } \\
\text { admin. }\end{array}$ & $\begin{array}{c}\text { Interest } \\
\text { on } \\
\text { general } \\
\text { debt }\end{array}$ & All other & $\begin{array}{c}\text { Total } \\
\text { expen. } \\
\text { need }\end{array}$ & $\begin{array}{l}\text { Index of } \\
\text { expen. } \\
\text { need }\end{array}$ & Rank \\
\hline United States & 1,427 & 545 & 973 & 510 & 401 & 412 & 464 & 322 & 261 & 691 & 6,007 & 100 & \\
\hline Alabama & 1,386 & 541 & 1,231 & 644 & 530 & 456 & 457 & 310 & 261 & 675 & 6,492 & 108 & 4 \\
\hline Alaska & 1,848 & 517 & 586 & 427 & 370 & 451 & 476 & 341 & 261 & 718 & 5,995 & 100 & 21 \\
\hline Arizona & 1,560 & 526 & 1,060 & 481 & 367 & 434 & 456 & 309 & 261 & 674 & 6,128 & 102 & 15 \\
\hline Arkansas & 1,395 & 500 & 1,497 & 624 & 531 & 357 & 442 & 287 & 261 & 645 & 6,539 & 109 & 3 \\
\hline California & 1,604 & 586 & 960 & 464 & 339 & 469 & 475 & 338 & 261 & 714 & 6,211 & 103 & 13 \\
\hline Connecticut & 1,474 & 525 & 720 & 500 & 349 & 364 & 486 & 356 & 261 & 738 & 5,772 & 96 & 30 \\
\hline Delaware & 1,266 & 565 & 667 & 507 & 412 & 368 & 471 & 333 & 261 & 707 & 5,557 & 93 & 38 \\
\hline Florida & 1,210 & 445 & 1,102 & 514 & 367 & 357 & 450 & 299 & 261 & 661 & 5,666 & 94 & 36 \\
\hline Georgia & 1,528 & 564 & 986 & 520 & 500 & 458 & 465 & 323 & 261 & 693 & 6,297 & 105 & 7 \\
\hline Hawaii & 1,151 & 457 & 925 & 420 & 255 & 313 & 455 & 307 & 261 & 672 & 5,216 & 87 & 50 \\
\hline Idaho & 1,498 & 541 & 899 & 463 & 512 & 315 & 446 & 293 & 261 & 653 & 5,880 & 98 & 22 \\
\hline Illinois & 1,489 & 585 & 937 & 487 & 344 & 496 & 475 & 338 & 261 & 714 & 6,126 & 102 & 15 \\
\hline Indiana & 1,439 & 573 & 722 & 522 & 474 & 438 & 464 & 322 & 261 & 692 & 5,908 & 98 & 22 \\
\hline Iowa & 1,220 & 539 & 778 & 470 & 529 & 294 & 448 & 296 & 261 & 656 & 5,491 & 91 & 46 \\
\hline Kansas & 1,376 & 541 & 838 & 479 & 588 & 339 & 453 & 303 & 261 & 666 & 5,846 & 97 & 25 \\
\hline Louisiana & 1,420 & 577 & 1,383 & 584 & 385 & 573 & 458 & 312 & 261 & 678 & 6,631 & 110 & 2 \\
\hline Maine & 1,177 & 438 & 1,063 & 575 & 449 & 255 & 442 & 287 & 261 & 645 & 5,593 & 93 & 38 \\
\hline Maryland & 1,382 & 523 & 642 & 458 & 368 & 518 & 476 & 341 & 261 & 718 & 5,688 & 95 & 34 \\
\hline Massachusetts & 1,317 & 563 & 830 & 543 & 316 & 350 & 475 & 339 & 261 & 715 & 5,709 & 95 & 34 \\
\hline Michigan & 1,554 & 582 & 878 & 547 & 410 & 479 & 478 & 344 & 261 & 722 & 6,255 & 104 & 9 \\
\hline Minnesota & 1,349 & 552 & 667 & 431 & 494 & 331 & 462 & 318 & 261 & 687 & 5,553 & 92 & 45 \\
\hline Mississippi & 1,409 & 552 & 1,508 & 669 & 539 & 472 & 446 & 292 & 261 & 652 & 6,800 & 113 & 1 \\
\hline Missouri & 1,290 & 521 & 891 & 523 & 504 & 402 & 453 & 304 & 261 & 667 & 5,816 & 97 & 25 \\
\hline Montana & 1,204 & 460 & 1,066 & 495 & 714 & 279 & 431 & 269 & 261 & 620 & 5,798 & 97 & 25 \\
\hline Nebraska & 1,238 & 520 & 860 & 447 & 605 & 309 & 444 & 289 & 261 & 648 & 5,619 & 94 & 36 \\
\hline Nevada & 1,441 & 484 & 595 & 452 & 365 & 448 & 457 & 310 & 261 & 676 & 5,489 & 91 & 46 \\
\hline New Hampshire & 1,315 & 495 & 584 & 480 & 390 & 289 & 462 & 318 & 261 & 687 & 5,282 & 88 & 49 \\
\hline New Jersey & 1,464 & 537 & 722 & 504 & 310 & 403 & 489 & 361 & 261 & 745 & 5,797 & 97 & 25 \\
\hline New Mexico & 1,501 & 502 & 1,321 & 514 & 568 & 401 & 446 & 293 & 261 & 653 & 6,460 & 108 & 4 \\
\hline New York & 1,351 & 557 & 1,162 & 545 & 268 & 403 & 470 & 331 & 261 & 704 & 6,052 & 101 & 19 \\
\hline North Carolina & 1,365 & 516 & 1,127 & 570 & 431 & 409 & 455 & 307 & 261 & 671 & 6,113 & 102 & 15 \\
\hline North Dakota & 1,209 & 540 & 1,161 & 458 & 1,008 & 271 & 435 & 275 & 261 & 629 & 6,248 & 104 & 9 \\
\hline Ohio & 1,385 & 550 & 856 & 510 & 376 & 386 & 467 & 326 & 261 & 697 & 5,814 & 97 & 25 \\
\hline Oklahoma & 1,365 & 522 & 1,071 & 518 & 575 & 363 & 444 & 290 & 261 & 649 & 6,059 & 101 & 19 \\
\hline Oregon & 1,325 & 519 & 865 & 480 & 419 & 307 & 454 & 305 & 261 & 669 & 5,605 & 93 & 38 \\
\hline
\end{tabular}




\begin{tabular}{|c|c|c|c|c|c|c|c|c|c|c|c|c|c|}
\hline State & $\begin{array}{l}\text { Elem and } \\
\text { secondary } \\
\text { education }\end{array}$ & $\begin{array}{l}\text { Higher } \\
\text { ed }\end{array}$ & $\begin{array}{l}\text { Pub. } \\
\text { welf. }\end{array}$ & $\begin{array}{l}\text { Health } \\
\text { and } \\
\text { hosp. }\end{array}$ & Highways & $\begin{array}{l}\text { Police } \\
\text { and } \\
\text { corrects. }\end{array}$ & $\begin{array}{l}\text { Environ. } \\
\text { and } \\
\text { housing }\end{array}$ & $\begin{array}{l}\text { Gov. } \\
\text { admin. }\end{array}$ & $\begin{array}{c}\text { Interest } \\
\text { on } \\
\text { general } \\
\text { debt }\end{array}$ & All other & $\begin{array}{l}\text { Total } \\
\text { expen. } \\
\text { need }\end{array}$ & $\begin{array}{l}\text { Index of } \\
\text { expen. } \\
\text { need }\end{array}$ & Rank \\
\hline Rhode Island & 1,208 & 562 & 911 & 555 & 283 & 369 & 460 & 314 & 261 & 681 & 5,603 & 93 & 38 \\
\hline South Carolina & 1,374 & 527 & 1,234 & 591 & 461 & 418 & 453 & 304 & 261 & 667 & 6,291 & 105 & 7 \\
\hline South Dakota & 1,224 & 491 & 874 & 447 & 868 & 256 & 431 & 270 & 261 & 621 & 5,745 & 96 & 30 \\
\hline Tennessee & 1,332 & 528 & 1,204 & 607 & 468 & 432 & 456 & 308 & 261 & 674 & 6,271 & 104 & 9 \\
\hline Texas & 1,659 & 574 & 1,191 & 462 & 410 & 431 & 462 & 318 & 261 & 687 & 6,456 & 107 & 6 \\
\hline Utah & 1,786 & 725 & 720 & 403 & 442 & 382 & 461 & 317 & 261 & 685 & 6,181 & 103 & 13 \\
\hline Virginia & 1,397 & 524 & 759 & 501 & 407 & 415 & 469 & 329 & 261 & 702 & 5,764 & 96 & 30 \\
\hline Washington & 1,444 & 539 & 852 & 484 & 373 & 354 & 466 & 324 & 261 & 695 & 5,791 & 96 & 30 \\
\hline West Virginia & 1,226 & 502 & 1,380 & 698 & 461 & 304 & 447 & 294 & 261 & 654 & 6,227 & 104 & 9 \\
\hline Wisconsin & 1,283 & 545 & 766 & 462 & 460 & 344 & 457 & 311 & 261 & 677 & 5,566 & 93 & 38 \\
\hline Wyoming & 1,378 & 528 & 664 & 479 & 854 & 320 & 450 & 299 & 261 & 661 & 5,894 & 98 & 22 \\
\hline
\end{tabular}


Table D12. Actual per capita direct general expenditures, FY 2002 (per capita dollars)

\begin{tabular}{|c|c|c|c|c|c|c|c|c|c|c|c|}
\hline State & $\begin{array}{c}\text { Elementary } \\
\text { and secondary } \\
\text { education }\end{array}$ & $\begin{array}{l}\text { Higher } \\
\text { education }\end{array}$ & $\begin{array}{c}\text { Public } \\
\text { welfare }\end{array}$ & $\begin{array}{c}\text { Health and } \\
\text { hospitals }\end{array}$ & Highways & $\begin{array}{l}\text { Police and } \\
\text { corrections }\end{array}$ & $\begin{array}{l}\text { Environment } \\
\text { and housing }\end{array}$ & $\begin{array}{l}\text { Governmental } \\
\text { administration }\end{array}$ & $\begin{array}{c}\text { Interest on } \\
\text { general } \\
\text { debt }\end{array}$ & All other & $\begin{array}{c}\text { Direct } \\
\text { general } \\
\text { expenditure }\end{array}$ \\
\hline United States & 1,427 & 545 & 973 & 510 & 401 & 412 & 464 & 322 & 261 & 691 & 6,007 \\
\hline Alabama & 1,136 & 607 & 929 & 911 & 372 & 261 & 407 & 213 & 183 & 472 & 5,491 \\
\hline Alaska & 2,339 & 760 & 1,615 & 410 & 1,429 & 686 & 965 & 816 & 667 & 3,489 & 13,175 \\
\hline Arizona & 1,061 & 497 & 707 & 282 & 352 & 438 & 413 & 302 & 201 & 493 & 4,745 \\
\hline Arkansas & 1,090 & 531 & 958 & 338 & 483 & 285 & 327 & 248 & 154 & 413 & 4,827 \\
\hline California & 1,521 & 582 & 1,016 & 599 & 328 & 545 & 590 & 447 & 248 & 856 & 6,732 \\
\hline Colorado & 1,306 & 635 & 628 & 478 & 630 & 429 & 497 & 325 & 286 & 841 & 6,054 \\
\hline Connecticut & 1,723 & 450 & 1,004 & 550 & 354 & 410 & 455 & 393 & 413 & 1,244 & 6,996 \\
\hline Delaware & 1,493 & 781 & 871 & 406 & 576 & 488 & 502 & 504 & 405 & 618 & 6,643 \\
\hline Florida & 1,116 & 347 & 749 & 448 & 403 & 465 & 539 & 293 & 250 & 609 & 5,219 \\
\hline Georgia & 1,443 & 456 & 873 & 566 & 344 & 389 & 419 & 281 & 133 & 513 & 5,416 \\
\hline Hawaii & 1,168 & 642 & 924 & 528 & 339 & 334 & 731 & 428 & 464 & 1,156 & 6,715 \\
\hline Idaho & 1,214 & 515 & 771 & 451 & 460 & 350 & 432 & 312 & 156 & 404 & 5,065 \\
\hline Illinois & 1,426 & 517 & 784 & 413 & 451 & 406 & 548 & 330 & 312 & 680 & 5,866 \\
\hline Indiana & 1,297 & 587 & 863 & 467 & 330 & 282 & 408 & 304 & 191 & 591 & 5,320 \\
\hline Iowa & 1,296 & 793 & 914 & 643 & 600 & 269 & 398 & 286 & 128 & 530 & 5,856 \\
\hline Kansas & 1,273 & 653 & 738 & 454 & 563 & 309 & 314 & 348 & 232 & 598 & 5,482 \\
\hline Kentucky & 953 & 587 & 1,178 & 353 & 477 & 279 & 339 & 247 & 364 & 491 & 5,268 \\
\hline Louisiana & 1,167 & 467 & 678 & 809 & 342 & 372 & 406 & 313 & 235 & 570 & 5,359 \\
\hline Maine & 1,389 & 431 & 1,381 & 385 & 476 & 252 & 427 & 326 & 253 & 804 & 6,124 \\
\hline Maryland & 1,496 & 650 & 871 & 274 & 341 & 476 & 532 & 302 & 251 & 678 & 5,871 \\
\hline Massachusetts & 1,600 & 393 & 894 & 492 & 508 & 400 & 485 & 320 & 505 & 1,004 & 6,600 \\
\hline Michigan & 1,592 & 727 & 980 & 562 & 322 & 410 & 399 & 287 & 238 & 560 & 6,075 \\
\hline Minnesota & 1,546 & 586 & 1,487 & 391 & 533 & 332 & 591 & 347 & 289 & 849 & 6,952 \\
\hline Mississippi & 1,030 & 642 & 1,129 & 746 & 431 & 273 & 269 & 221 & 173 & 450 & 5,365 \\
\hline Missouri & 1,301 & 466 & 972 & 428 & 435 & 323 & 312 & 229 & 183 & 464 & 5,114 \\
\hline Montana & 1,243 & 556 & 737 & 415 & 596 & 321 & 492 & 367 & 231 & 589 & 5,546 \\
\hline Nebraska & 1,436 & 690 & 986 & 351 & 535 & 304 & 385 & 252 & 148 & 556 & 5,645 \\
\hline Nevada & 1,280 & 374 & 517 & 426 & 586 & 532 & 455 & 420 & 312 & 526 & 5,427 \\
\hline New Hampshire & 1,418 & 440 & 807 & 144 & 395 & 256 & 329 & 283 & 318 & 582 & 4,973 \\
\hline New Jersey & 1,866 & 470 & 770 & 319 & 345 & 469 & 521 & 327 & 277 & 975 & 6,341 \\
\hline New Mexico & 1,351 & 788 & 1,119 & 447 & 616 & 421 & 393 & 337 & 204 & 488 & 6,164 \\
\hline New York & 1,999 & 417 & 1,697 & 679 & 370 & 594 & 566 & 390 & 435 & 1,267 & 8,414 \\
\hline North Carolina & 1,155 & 619 & 921 & 732 & 363 & 322 & 400 & 210 & 162 & 475 & 5,359 \\
\hline North Dakota & 1,181 & 805 & 1,047 & 164 & 727 & 216 & 557 & 284 & 237 & 914 & 6,132 \\
\hline Ohio & 1,446 & 511 & 1,076 & 478 & 359 & 371 & 435 & 408 & 236 & 557 & 5,876 \\
\hline Oklahoma & 1,257 & 639 & 915 & 374 & 443 & 324 & 315 & 248 & 150 & 540 & 5,205 \\
\hline Oregon & 1,364 & 720 & 1,148 & 623 & 340 & 454 & 548 & 451 & 209 & 668 & 6,525 \\
\hline Pennsylvania & 1,334 & 468 & 1,175 & 418 & 429 & 397 & 414 & 278 & 328 & 705 & 5,947 \\
\hline Rhode Island & 1,473 & 449 & 1,559 & 280 & 310 & 371 & 424 & 348 & 303 & 803 & 6,321 \\
\hline South Carolina & 1,402 & 519 & 1,065 & 766 & 363 & 315 & 302 & 314 & 282 & 473 & 5,801 \\
\hline
\end{tabular}




\begin{tabular}{|c|c|c|c|c|c|c|c|c|c|c|c|}
\hline State & $\begin{array}{c}\text { Elementary } \\
\text { and secondary } \\
\text { education }\end{array}$ & $\begin{array}{l}\text { Higher } \\
\text { education }\end{array}$ & $\begin{array}{l}\text { Public } \\
\text { welfare }\end{array}$ & $\begin{array}{c}\text { Health and } \\
\text { hospitals }\end{array}$ & Highways & $\begin{array}{l}\text { Police and } \\
\text { corrections }\end{array}$ & $\begin{array}{l}\text { Environment } \\
\text { and housing }\end{array}$ & $\begin{array}{l}\text { Governmental } \\
\text { administration }\end{array}$ & $\begin{array}{c}\text { Interest on } \\
\text { general } \\
\text { debt }\end{array}$ & All other & $\begin{array}{c}\text { Direct } \\
\text { general } \\
\text { expenditure }\end{array}$ \\
\hline South Dakota & 1,238 & 476 & 795 & 224 & 763 & 261 & 437 & 262 & 227 & 424 & 5,108 \\
\hline Tennessee & 1,062 & 511 & 1,115 & 570 & 306 & 288 & 322 & 215 & 159 & 450 & 4,998 \\
\hline Texas & 1,476 & 575 & 686 & 465 & 338 & 374 & 336 & 208 & 228 & 441 & 5,127 \\
\hline Utah & 1,227 & 919 & 688 & 370 & 438 & 352 & 460 & 394 & 183 & 514 & 5,544 \\
\hline Vermont & 1,519 & 695 & 1,228 & 142 & 588 & 278 & 429 & 413 & 265 & 615 & 6,172 \\
\hline Virginia & 1,430 & 571 & 643 & 438 & 426 & 371 & 392 & 310 & 234 & 583 & 5,399 \\
\hline Washington & 1,350 & 656 & 1,022 & 661 & 392 & 369 & 640 & 287 & 254 & 739 & 6,370 \\
\hline West Virginia & 1,263 & 554 & 1,185 & 286 & 579 & 218 & 330 & 354 & 247 & 453 & 5,469 \\
\hline Wisconsin & 1,556 & 682 & 1,022 & 383 & 549 & 450 & 493 & 285 & 268 & 563 & 6,250 \\
\hline Wyoming & 1,716 & 722 & 764 & 1,034 & 956 & 463 & 654 & 488 & 256 & 667 & 7,719 \\
\hline
\end{tabular}

